\title{
Surficial Geology and Stratigraphy of Pleistocene Lake Manix, San Bernardino County, California
}

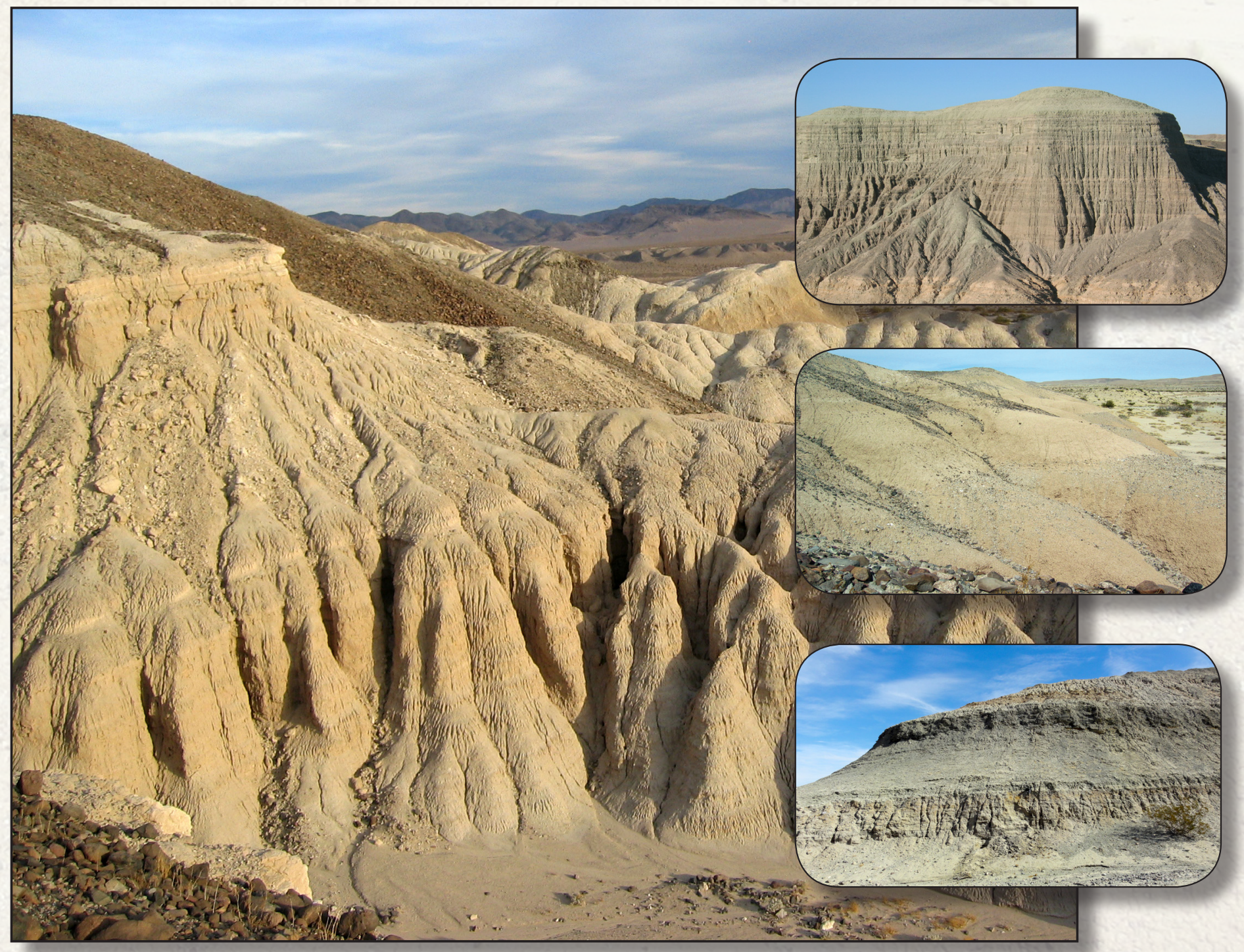

Pamphlet to accompany

Scientific Investigations Map 3312 


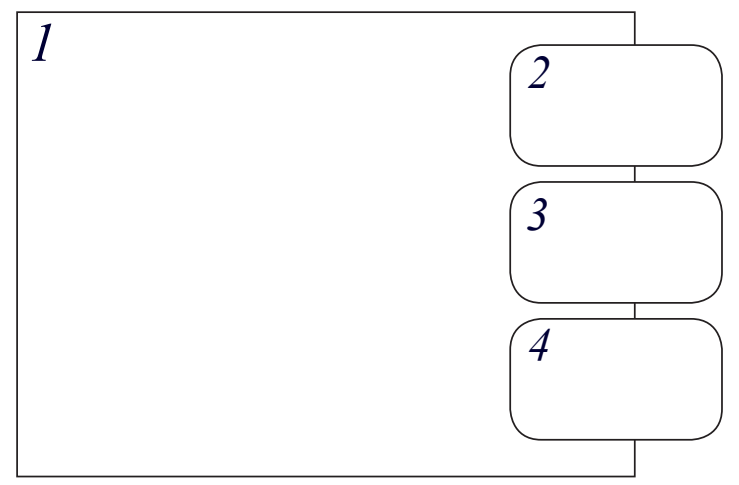

Cover: 1, View to east of playa and distal-fan deposits of unit Qmr (Mojave River formation) near western end of Buwalda Ridge in Cady subbasin; 2, view showing Q17 over Qia (vertical cliff) over Qvg (more gullied, steeply sloping) over pink QTcg with white calcic soil at top; 3, view to northeast of playa and distal-fan deposits of unit Qp in Afton subbasin; and 4, Units Q18, Q17, and Q16 exposed on south side of Mojave River, Afton subbasin, station M11-109. 


\section{Surficial Geology and Stratigraphy of Pleistocene Lake Manix, San Bernardino County, California}

By Marith C. Reheis, Joanna R. Redwine, Elmira Wan, John P. McGeehin, and D. Paco VanSistine

Pamphlet to accompany

Scientific Investigations Map 3312 


\title{
U.S. Department of the Interior SALLY JEWELL, Secretary
}

\section{U.S. Geological Survey Suzette M. Kimball, Acting Director}

\author{
U.S. Geological Survey, Reston, Virginia: 2014
}

For more information on the USGS - the Federal source for science about the Earth, its natural and living resources, natural hazards, and the environment, visit http://www.usgs.gov or call 1-888-ASK-USGS.

For an overview of USGS information products, including maps, imagery, and publications, visit http://www.usgs.gov/pubprod

To order this and other USGS information products, visit http://store.usgs.gov

Any use of trade, firm, or product names is for descriptive purposes only and does not imply endorsement by the U.S. Government.

Although this information product, for the most part, is in the public domain, it also may contain copyrighted materials as noted in the text. Permission to reproduce copyrighted items must be secured from the copyright owner.

Suggested citation:

Reheis, M.C., Redwine, J.R, Wan, Elmira, McGeehin, J.P., and VanSistine, D.P., 2014, Surficial geology and stratigraphy of Pleistocene Lake Manix, San Bernardino County, California: U.S. Geological Survey Scientific Investigations Map 3312, 46 p., 2 sheets, scale 1:24,000, http://dx.doi.org/10.3133/sim3312.

ISSN 2329-132X (online) 


\section{Contents}

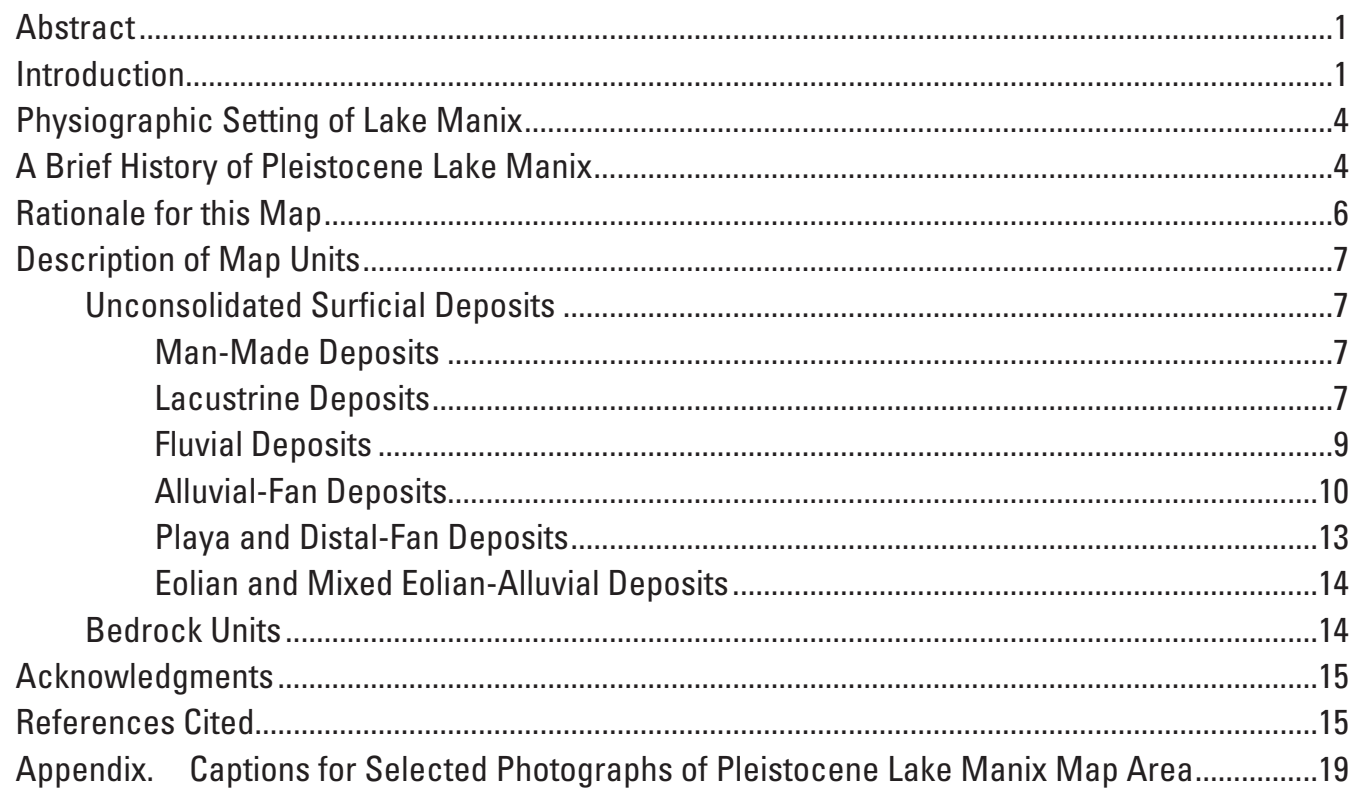

\section{Sheets}

1. Map of Surficial Geology and Stratigraphy of Pleistocene Lake Manix, San Bernardino County, California.............................................................................. link

2. Stratigraphic sections of Pleistocene Lake Manix map area, San Bernardino County, California link

2A. Stratigraphic sections from northern Manix Wash to south of Mojave River

2B. Stratigraphic sections from western Buwalda Ridge to Dunn

2C. Stratigraphic sections from Dunn wash and Afton areas

2D. Stratigraphic sections from north Afton beach ridge in Afton subbasin

\section{Figures}

1. Map showing Mojave River drainage basin in southern California ...................................2

2. Index map superimposed on digital orthophoto map showing Pleistocene Lake Manix, surficial geologic map area, and boundaries of 7.5' USGS quadrangles.

\section{Tables}

1. Radiocarbon ages and site information from Cady and Afton subbasins of Lake Manix

2. Locations, correlations, age ranges and geochemical compositions of tephra layers in map area.

3. Site data for Pleistocene Lake Manix surficial map .........................................................29

4. Fault and altitude data for Pleistocene Lake Manix surficial map ....................................38 


\section{Conversion Factors}

Inch/Pound to SI

\begin{tabular}{lcl}
\hline Multiply & By & To obtain \\
\hline inch (in.) & Length & \\
inch (in.) & 2.54 & centimeter (cm) \\
foot (ft) & 25.4 & millimeter (mm) \\
mile (mi) & 0.3048 & meter (m) \\
\hline & 1.609 & kilometer $(\mathrm{km})$ \\
SI to Inch/Pound & & \\
\hline Multiply & By & To obtain \\
\hline & Length & \\
\hline centimeter $(\mathrm{cm})$ & 0.3937 & inch (in.) \\
meter $(\mathrm{m})$ & 3.281 & foot (ft) \\
kilometer $(\mathrm{km})$ & 0.6214 & mile (mi) \\
\hline
\end{tabular}

Temperature in degrees Celsius $\left({ }^{\circ} \mathrm{C}\right)$ may be converted to degrees Fahrenheit $\left({ }^{\circ} \mathrm{F}\right)$ as follows: ${ }^{\circ} \mathrm{F}=\left(1.8 \times{ }^{\circ} \mathrm{C}\right)+32$

Temperature in degrees Fahrenheit $\left({ }^{\circ} \mathrm{F}\right)$ may be converted to degrees Celsius $\left({ }^{\circ} \mathrm{C}\right)$ as follows:

$$
{ }^{\circ} \mathrm{C}=\left({ }^{\circ} \mathrm{F}-32\right) / 1.8
$$

$\mathrm{Ka}$, thousand years before present; Ma, million years before present.

Vertical coordinate information is referenced to the North American Vertical Datum of 1988 (NAVD 88).

Horizontal coordinate information is referenced to the North American Datum of 1983 (NAD 83).

Altitude, as used in this report, refers to distance above the vertical datum, or meters above sea level (masl) as indicated in the report. 


\title{
Surficial Geology and Stratigraphy of Pleistocene Lake Manix, San Bernardino County, California
}

\author{
By Marith C. Reheis, ${ }^{1}$ Joanna R. Redwine, ${ }^{2}$ Elmira Wan, ${ }^{1}$ and D. Paco VanSistine ${ }^{1}$
}

\section{Abstract}

Pluvial Lake Manix and its surrounding drainage basin, in the central Mojave Desert of California, has been a focus of paleoclimate, surficial processes, and neotectonic studies by the U.S. Geological Survey (USGS) since about 2004. The U.S. Geological Survey initiated studies of Lake Manix deposits to improve understanding of the paleoclimatic record and the shifts in atmospheric circulation that controlled precipitation in the Mojave Desert. Until approximately 25,000 years ago, Lake Manix was the terminus of the Mojave River, which drains northeasterly from the San Bernardino Mountains; the river currently terminates in the Soda Lake and Silver Lake playas. Pleistocene Lake Manix occupied several subbasins at its maximum extent. This map focuses on the extensive exposures created by incision of the Mojave River and its tributaries into the interbedded lacustrine and alluvial deposits within the central (Cady) and northeastern (Afton) subbasins of Lake Manix, and extends from the head of Afton Canyon to Manix Wash. The map illuminates the geomorphic development and depositional history of the lake and alluvial fans within the active tectonic setting of the eastern California shear zone, especially interactions with the left-lateral Manix fault.

Lake Manix left an extraordinarily detailed but complex record of numerous transgressive-regressive sequences separated by desiccation and deposition of fan, eolian, and fluvial deposits, and punctuated by tectonic movements and a catastrophic flood that reconfigured the lake basin. Through careful observation of the intercalated lacustrine and fan sequences and by determining the precise elevations of unit contacts, this record was decoded to understand the response of the lake and river system to the interplay of climatic, geomorphic, and tectonic forces. These deposits are exposed in steep badland topography. Mapping was carried out mostly at scales of $1: 12,000$, although the map is presented at 1:24,000 scale, and employs custom unit nomenclature, with multiple subdivided lacustrine and alluvial fan units. In addition, many important units are very thin and cannot be mapped separately, or are covered by thin eolian sand, so these are commonly portrayed as stacks of units or combined units. These details are more

\footnotetext{
${ }^{1}$ U.S. Geological Survey
}

${ }^{2}$ U.S. Bureau of Reclamation accurately portrayed in the measured sections that accompany the map. Altitudes of many contacts were obtained using differentially corrected Global Positioning System (GPS) or, in some cases, lidar (light detection and ranging) data.

\section{Introduction}

Pluvial Lake Manix, in the central Mojave Desert of California, has been a focus of paleoclimate, surficial processes, and neotectonic studies by the U.S. Geological Survey (USGS) since about 2004. From the middle Pleistocene until the late Pleistocene, Lake Manix was the primary terminus of the Mojave River, which drains northeasterly from the San Bernardino Mountains; when in flood, the river currently transits Soda Lake playa in the Mojave National Forest and terminates in the Silver Lake playa (fig. 1). Southwestern lakes are sensitive recorders of precipitation and temperature on millennial to decadal timescales, but there are few detailed studies of pluvial lakes in the Mojave Desert region. The stratigraphy, paleontology, and broad lake-level fluctuations of Lake Manix were established by Ellsworth (1932; Blackwelder and Ellsworth, 1936), Jefferson (2003, and references therein), and Meek (1989a, 1989b, 1990, 2000). The U.S. Geological Survey initiated paleoclimate studies to improve understanding of the shifts in atmospheric circulation that control precipitation in the Mojave Desert. The initial focus was on stratigraphic sequences of lacustrine and alluvial-fan deposits, and in 2005 a 45-m-long core was obtained from the thickest preserved sequence of lacustrine deposits for detailed study (fig. 2). Initial conflicts between the stratigraphy and sedimentology expressed in the core and interpreted from outcrops in previous work led to a need to map the exposed sedimentary section in detail.

Lake Manix occupied several subbasins at its maximum extent (fig. 2). This report focuses on the extensive exposures created by incision of the Mojave River and its tributaries into the interbedded lacustrine and alluvial deposits within the central (Cady) and northeastern (Afton) subbasins, and extends from the head of Afton Canyon to Manix Wash. Deposits west of Manix Wash are included in mapping by David M. Miller (USGS, unpub. data). Other workers (Dudash, 2006; D.M. Miller, USGS, unpub. data) have mapped lacustrine deposits in the northern, relatively undissected Coyote Lake subbasin. 


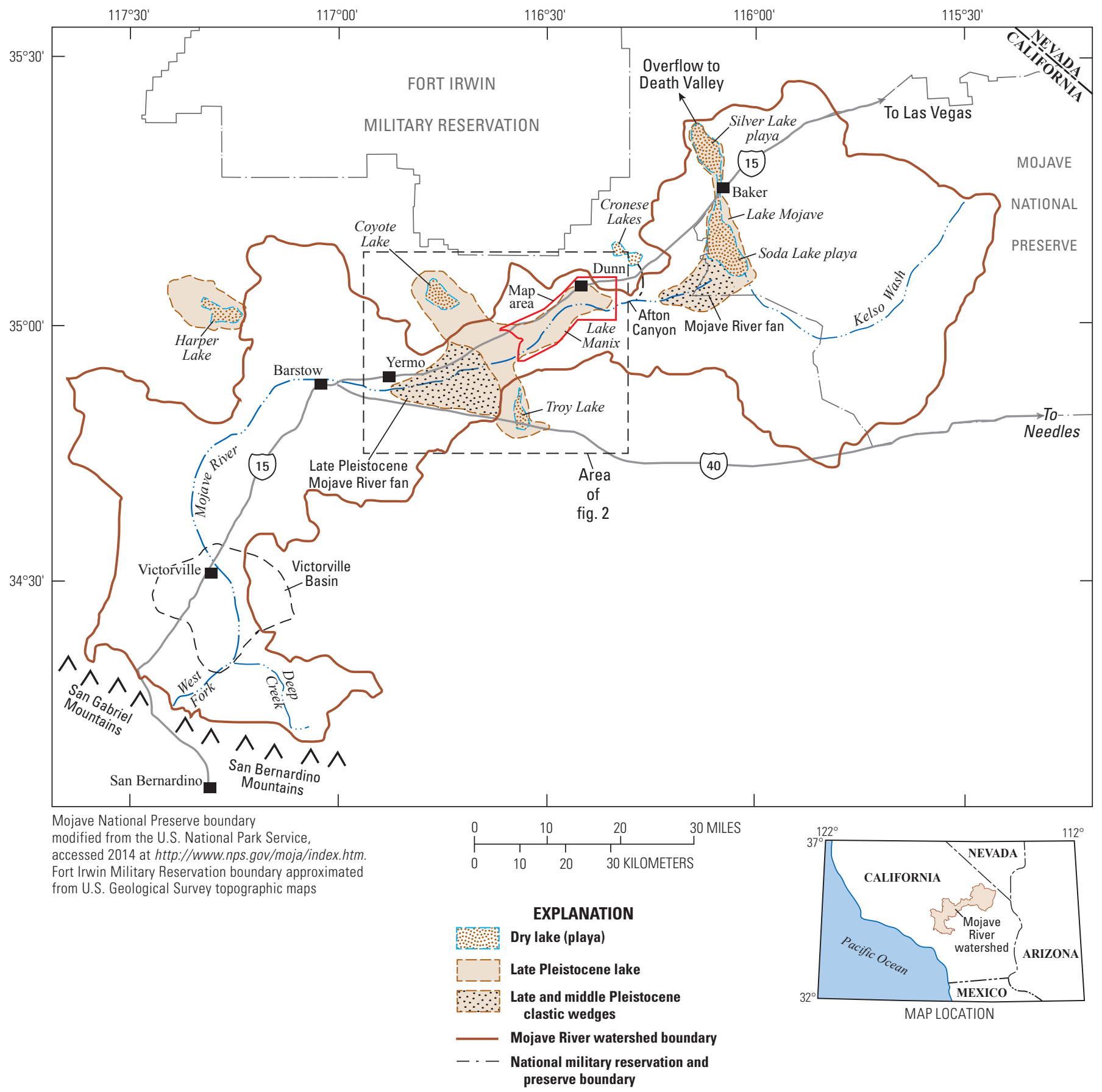

Figure 1. Mojave River drainage basin in southern California (modified from Enzel and others, 2003). During historic high-precipitation years, most recently in early 2005 and late 2010, storms in the headwaters of the San Bernardino Mountains generated riverflow into Silver Lake playa and Cronese Lakes. Red line shows approximate map area. 


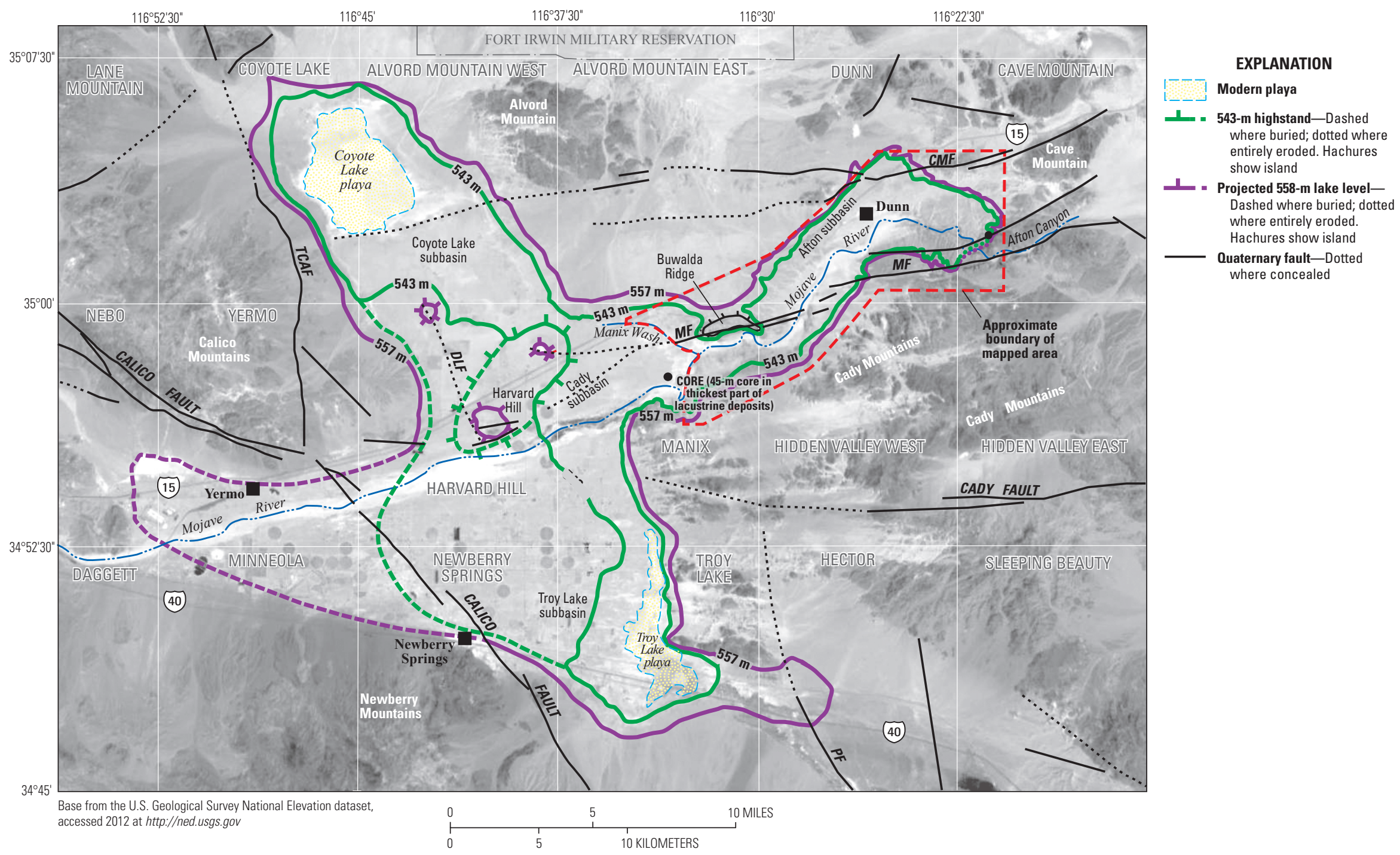

Figure 2. Index map superimposed on digital orthophoto map showing Pleistocene Lake Manix, surficial geologic map area (red dashed line), and boundaries of 7.5' USGS quadrangles. Green line is the 543-meters above sea level (masl) highstand level that depicts the minimum extent of Lake Manix during the late Pleistocene; western margin is not known due to progradation during highstands and later burial by Mojave River alluvium. Purple line is the 558-m lake limit projected from highest unfaulted shoreline features recognized during mapping (Reheis and Redwine, 2008). CMF, Cave Mountain fault; DLF, Dolores Lake fault; MF, Manix fault; PF, Pisgah fault; TCAF, Tin Can Alley fault. 


\section{Physiographic Setting of Lake Manix}

The Manix basin in south-central California is one of a chain of interconnected basins crossed and linked by the northeast-flowing Mojave River (fig. 1). Prior to uplift of the Transverse Ranges during the Pliocene, regional drainage was generally to the south, thus the history of the Mojave River has been one of drainage reversal and basin integration (Cox and others, 2003). During its evolution, the river has integrated several basins that drained internally during the late Pliocene and early Pleistocene, including the Victorville, Harper, Manix, and Soda Lake basins (Cox and others, 2003; Enzel and others, 2003). Each basin contains fluvial and lacustrine sediments indicating the arrival and ponding of the river, and a record of paleoclimatic fluctuations when that basin served as the terminus (for example, Enzel and others, 2003) of the Mojave River. Sediments in the Manix basin contain a record of Mojave River discharge and lake fluctuations during the middle Pleistocene and most of the late Pleistocene (for example, Jefferson, 2003).

Sediments derived from the surrounding mountain ranges are abundant in the Pliocene and Pleistocene deposits of the Manix basin, and sediment composition sheds light on source and tectonic history. The Manix basin is flanked to the south by the Cady Mountains (fig. 2), a complex of Tertiary volcanic and sedimentary rocks (Danehy, E.A., and Collier, J.T., Southern Pacific Company, unpub. data, 1958; Mosely, 1978; Bortugno and Spittler, 1986), with minor Mesozoic granitic rocks. Sediments in the Manix basin derived from the south, especially fan deposits, are dominated by mafic volcanic clasts, but locally also contain foliated granitoids and siliceous dike rocks. To the northwest, the Calico Mountains are composed of a wide compositional range of dacitic volcanic and volcaniclastic rocks and sedimentary rocks (Dibblee, 1968; Singleton and Gans, 2008). Alvord Mountain to the north is composed of Paleozoic schist and marble, Mesozoic granitic rocks, Tertiary volcanic rocks, and arkosic sandstone and lacustrine shale (Byers, 1960; Fillmore, 1993). These rocks probably contributed the sediment composing most of the Pleistocene fan deposits on the north side of the Mojave River (Miller and others, 2011), and likely also the coarse-grained fraction of the early Quaternary Mojave River formation (informal name; Nagy and Murray, 1991). Finally, Cave Mountain to the northeast is a massive complex of mafic and felsic Mesozoic plutonic rocks (Danehy, E.A., and Collier, J.T., Southern Pacific Company, unpub. data, 1958) and was the source of the fanglomerate of Cave Mountain, which contains distinctive cobble- to boulder-sized clasts of dark iron-rich rock.

Externally sourced deposits of the Mojave River are dominated by granitic rocks in the San Bernardino Mountains headwaters as well as older basin fill originally derived from rocks in the San Bernardino Mountains and rocks exposed between Yermo and Victorville (fig. 1). The sand and gravel bedload is dominated by granitic grus, with common wellrounded, polished orange quartzite pebbles and lesser amounts of volcanic clasts. The silt and clay fraction that constitutes Lake Manix sediment deposited in quiet-water settings is commonly grayish olive, olive gray, or greenish-gray in color. These sediments are thought to have been derived from the Cretaceous Pelona Schist, which is now cut off from the Mojave River drainage basin by movement along the San Andreas Fault but was a major contributor to late Cenozoic basin fill exposed near Victorville (Morton and Miller, 2006).

The Lake Manix basin is composed of several subbasins: the northern Coyote Lake subbasin, the central Cady subbasin (previously, this was informally referred to as the Manix subbasin), the southern Troy Lake subbasin, and the northeastern Afton subbasin (fig. 2). There is no clear boundary or buried divide between the Cady and Troy Lake subbasins. The Troy Lake area has not been incised and has been almost completely filled by fluvial deposits of the Mojave River during and after the late Pleistocene phase of Lake Manix (Reynolds and Reynolds, 1985; Meek, 1990). In contrast, the Cady and Coyote Lake subbasins are separated by low hills of Tertiary rocks and are connected by a relatively high bedrock controlled sill at about 540-meters above sea level (masl) through which water was transferred between the subbasins when lake level was high (Meek, 1990). Fluvial terraces and dated lacustrine deposits suggest that occasionally the Mojave River fed the Coyote Lake subbasin directly (Meek, 1994, 2004; Miller, Dudash, and McGeehin, 2009). The Cady and Afton subbasins are not currently separated by a divide, but the sedimentary sequences preserved within them indicate that the basins were separate in the past. The boundary between them is defined by Buwalda Ridge. This ridge, composed of Tertiary fanglomerate, is bounded and internally cut by the Manix fault. The Manix fault extends eastward and coincides with the former eastern threshold of Lake Manix at the head of Afton Canyon. Sheared zones in fanglomerate units along this fault probably played a significant role in the drainage integration history.

\section{A Brief History of Pleistocene Lake Manix}

Previous stratigraphic studies of Lake Manix sediments have focused on outcrops in the Cady subbasin (Jefferson, 2003, and citations therein), and other sites mainly in the Afton and Coyote subbasins (Meek, 1990). Jefferson (2003) conducted stratigraphic and paleontologic studies near the confluence of the Mojave River and Manix Wash (fig. 2), and interpreted these deposits to represent at least four major lake phases or cycles deposited during glacial periods beginning about $560 \mathrm{ka}$ (Marine Isotope Stage (MIS) 14; age boundaries from Lisiecki and Raymo, 2005). Deposits of the oldest two lake cycles are poorly dated; the sediments have normal polarity, and one bone yielded an infinite uranium-thorium (U-Th) age of $>350 \mathrm{ka}$ (J.L. Bischoff, USGS, cited in Jefferson, 2003). Deposits of the third lake cycle interpreted by Jefferson as perennial-lake sediments and correlated with MIS 6 (his informal "upper Member C") are correlative to units Q17 and Q16 
of this map (photo 1 on sheet 1, and see appendix). (Numbered photographs are contained in the appendix that accompanies this report. Selections of these photos are presented on the two map sheets to illustrate stratigraphic relations.) They contain a tephra layer near the base that has an age of $184 \pm 4 \mathrm{ka}$, based on chemical correlation with a rhyolite in the Sierra Nevada to the northwest recently re-dated using ${ }^{40} \mathrm{Ar} /{ }^{39} \mathrm{Ar}$ on sanidine by Robert Fleck, USGS (Reheis and others, 2012). Sediments representing a sequence of fluctuating lake levels and deltaic sands of the prograding Mojave River were correlated with MIS 4 and 2 ("Member D," correlative to unit Q18 of this map) on the basis of several U-Th ages on bone and several radiocarbon ages (Jefferson, 2003, p. 48). Numerous beach deposits extending to $\sim 543$ masl rim the Manix basin. Mollusk shells from these deposits were dated by Meek (1989b, 2000) and interpreted to indicate multiple lake highstands. Both authors correlated the extensive greenish lacustrine muds that underlie these beach deposits in the Afton subbasin with "upper Member C" of Jefferson (2003). Both also noted the apparent absence of older lacustrine deposits in the Afton subbasin, with the exception of one section measured by Meek (1990), and ascribed this to more extensive erosion along the valley axis in that area.

Meek (1989a, 2004) interpreted the geomorphic record of overflow that formed the downstream Lake Mojave as rapid incision to the base of Lake Manix sediments, followed by a second phase of Afton Canyon incision that was slower than the initial incision. Reheis and Redwine (2008) generally concurred with this scenario, and provided several more radiocarbon ages that indicated multiple lake highstands at or near 543 masl prior to final overtopping and incision of the threshold not later than about $25 \mathrm{cal}$ ka (calibrated thousand years before present). They also identified deposits of one or more older lake phases that reached higher lake levels between 547-549 and about 558 masl.

The USGS obtained a 45-m-long core of interbedded lacustrine and alluvial deposits near the confluence of Manix Wash and the Mojave River in 2005 (Reheis and others, 2012). We also undertook mapping and stratigraphic investigations to improve understanding of the history of Lake Manix and to provide geologic context for this core (Miller and McGeehin, 2007; Reheis and others, 2007; Reheis and Redwine, 2008; Reheis and Miller, 2010). These studies have resulted in several revisions to the previously established stratigraphy and history of Lake Manix.

Interpretation of paleomagnetic data from the Manix core suggests that a lake first occupied the area of the core site (fig. 2) at about 450 ka during MIS 12 (Reheis and others, 2012). Eight phases of shallow to deep lakes, numbered from oldest to youngest and separated by alluvial-fan deposits or soils, are identified from sedimentology (only phases Q14-Q18 are recognized within the map area). However, the youngest two phases in the core, Q17 and Q|8, indicated generally shallow water depth with only brief intervals of deeper water at the core site, and that mudflat or alluvial environments were common following the deposition of the Manix tephra at $184 \mathrm{ka}$. This interpretation is consistent with outcrop studies by Oviatt and others (2007), but differs from that of Jefferson (2003), who interpreted a moderate to deep lake during Q17 time, equivalent to his "upper Member C." In contrast, correlative deposits in the Afton subbasin, mapped herein as unit Q17, do indicate the presence of a moderately deep lake.

The discrepancies between strata in the Cady and Afton subbasins have been resolved by our mapping, which has identified a lacustrine unit, Q16, which was not recognized by previous workers. In the Afton subbasin, this unit largely consists of bedded sand, but in one critical location (sheet $2 C$, section M07-159; photo 20) fine-grained strata of Q16 contain the Manix tephra. The Manix tephra is chemically correlated to rhyolite in Long Canyon, southern California, which was previously dated at $\sim 185 \mathrm{ka}$ by K-Ar on sanidine (Jefferson, 2003) and recently re-dated by ${ }^{40} \mathrm{Ar} /{ }^{39} \mathrm{Ar}$ at $184 \pm 4 \mathrm{ka}$ (Reheis and others, 2012). The QI6 unit overlies fluvial sand and gravel (unit Qof) that locally includes reworked clasts of green lacustrine mud, and in a few localities in the Afton subbasin, several meters of chaotically bedded blocks (as much as $2 \mathrm{~m}$ across) of semi-indurated green lake mud, silt, and sand mixed with blocks of brown playa mud (photo 35 on sheet $2 B$, section M06-100; Reheis and others, 2007). The chaotically bedded deposits are interpreted as the result of deposition caused by a catastrophic failure of a former lake threshold on the south side of Buwalda Ridge, astride the Manix fault (photo 49 on sheet 1). This event was followed by deposition of sand and gravel by a high-energy stream draining the upstream subbasins, and a brief lacustrine period during which the Manix tephra was deposited. Thus, this subbasin integration event occurred shortly before $184 \mathrm{ka}$. After this time, the Afton subbasin was the new depocenter of Lake Manix, and during much of this period the core site was probably exposed or in very shallow water (Reheis and others, 2012).

After the subbasins were integrated, Lake Manix rose at least once to a level as much as $10-15 \mathrm{~m}$ higher than its previously recognized highstands at about 543 masl, during or after MIS 6 (Reheis and Redwine, 2008). These very high levels are represented by eroded beach barriers in both the Cady and Afton subbasins (sheet 1, fig. 2) and locally, by fan-delta deposits exposed in arroyos (notably, in the informally named Field wash and nearby drainages). During this time, the lake probably discharged episodically eastward into the Soda Lake basin (fig. 1) and may have incised the threshold at the head of the present-day Afton Canyon to about 543 masl. During subsequent highstands of MIS 4(?) and 3, the lake repeatedly rose to about 543 masl (Meek, 1990, 2000; Reheis and Redwine, 2008; Reheis and others, 2010), maintained there in part by the shallow threshold between the Cady and Coyote Lake subbasins (fig. 2; Meek, 2004). The Afton Canyon threshold failed at about $25 \mathrm{cal} \mathrm{ka}$; no recessional shorelines younger than this have been recognized, but younger lakes fed by direct inflow from the Mojave River episodically occupied the Coyote Lake subbasin (Meek, 1994; Dudash, 2006; Miller, Dudash, and McGeehin, 2009). Subsequent incision has exposed extensive, intricate badlands-type outcrops of interbedded lake and alluvial deposits (photos 1, 3, and 4). 


\section{Rationale for this Map}

This surficial-deposits map combines the western portion of the surficial map of the Afton Canyon area (J.R. Redwine, U.S. Bureau of Reclamation, unpub. data) with mapping carried out by Reheis to refine lake-unit stratigraphy and to extend mapping to the mouth of Manix Wash. Some of the subdivisions of tributary and alluvial-fan deposits of Redwine (U.S. Bureau of Reclamation, unpub. data) were combined in this map, and in some cases lacustrine units are emphasized rather than thin overlying fan or eolian deposits. The thin sedimentary units are commonly exposed in steep badland topography, creating an intricate maze not easily depicted. Therefore, mapping was carried out mostly at scales of 1:12,000 and employs custom unit nomenclature, with multiple subdivided lacustrine and alluvial fan units that are commonly portrayed as stacks of units or combined units. Southwest of the Afton Canyon area mapped by Redwine, fan and eolian deposits that postdate Lake Manix were mapped from aerial photographs with minor field verification. Less detailed mapping also characterizes the northeastern corner of the map outside the limit of lacustrine deposition. Van Sistine produced the topographic and orthographic base maps and the GIS database.
Many radiocarbon ages were obtained for Anodonta shells that are abundant in the lacustrine gravel, sand, and muddy sand (photo 5); analyses were conducted by McGeehin. Sample numbers and ages are given in table 1. Several tephra layers were also sampled (for example, photos 51 and 58) and their correlated ages (table 2), based on chemical analysis of glass by Wan in the USGS Tephrochronology Laboratory, help constrain ages of older Pleistocene and Pliocene units (see Description of Map Units).

Numerous stratigraphic sections were measured at varying levels of detail, ranging from centimeter scale using a measuring tape, to decimeter scale using an Abney level and Jacob's staff, and to meter scale using estimation. These sections illuminate the relations among various lake and alluvial-fan units, show buried soils that represent hiatuses in deposition, and show the relations between lake histories in the Cady and Afton subbasins. Selected sections are shown in sheet 2 and are keyed to locations on the map. Locations and altitudes of most of the sections, as well as many contacts (see table 3), were obtained using differentially corrected GPS; these altitudes are considered accurate to within $\pm 1 \mathrm{~m}$. Table 4 contains fault and attitude data for the map area. 


\section{DESCRIPTION OF MAP UNITS}

[Combined map symbols (for example, Qyao+Qyay) are used where two Quaternary map units are interspersed at such a small scale that separating map units was impractical. The first unit listed is considered dominant in the area; the second unit must occur in at least 20 percent of the area to be listed. Fractional map symbols (for example, Qia7/Q17) are used where a thin veneer of a younger unit overlies an older unit, especially common for alluvial-fan deposits interbedded with lacustrine sediment and for eolian deposits. Unit names are locally queried where identification is uncertain. Ages of alluvial and eolian deposits are classified as young, intermediate, or old based on surface micro-topography, pattern and degree of channel dissection of alluvial-fan surfaces, degree of soil development (Soil Survey Staff, 1999), desert pavement development, and intensity of rock varnish developed on surface clasts (Miller, Bedford, and others, 2009). Units so classified based on field observations are extended into additional areas through interpretation of aerial photographs. Correlations with locally dated deposits provide age control for these deposits (Bedford, 2003; Miller and others, 2010). This report follows the currently accepted age of $2.6 \mathrm{Ma}$ for the Pliocene-Pleistocene boundary (Geological Society of America, 2012), and thus revises the age of some units such as the informal Mojave River formation]

\section{Unconsolidated Surficial Deposits}

\section{Man-Made Deposits}

d

Disturbed areas (modern) - Unconsolidated to loosely compacted rubble composed of silt, sand, and rock. Mapped mainly along the interstate highway and railroad beds. Locally includes bulldozed areas

\section{Lacustrine Deposits}

Mapped lacustrine units, numbered from oldest (QI4) to youngest (QL8) are based on correlation with the Manix core, located just west of map area on the west side of Manix Wash (fig. 2) (Reheis and others, 2012); units Ql1-QI3 represented in that core are not recognized within the map area, but may locally interfinger with the upper part of units Qalg and Qvg west of Buwalda Ridge. Lake units are typically separated in outcrop by intervening thin (commonly $<1 \mathrm{~m}$ thick) alluvial-fan deposits with buried soils, which are capped by a layer of tufa-coated clasts that mark the base of the next younger lake unit. Those fan units older than Q|6, mapped only in the Cady subbasin, are mapped as part of the underlying lake units, but are identified in measured sections.

QI Lacustrine deposits, undivided (late and middle Pleistocene)—Lacustrine gravel, sand, silt, and clay. Mapped in only a few places where stratigraphy is confounded by faults and deposits are mostly obscured by colluvium

Q18

Lacustrine deposits, unit 8 (late Pleistocene) - Primarily lacustrine gravel and sand deposited in nearshore environment (photo 6 , sheet $2 D$ ). Individual beds moderately sorted. Planar bedded, with finer-grained beds locally exhibiting oscillatory wave ripples. Beds horizontal to dipping as much as $20-25^{\circ}$ in nearshore settings. May be expressed morphologically as dissected beach barrier or spit. Where deposited in an active alluvial-fan setting, beds strongly resemble alluvial clast-supported deposits but are better sorted and bedded (photos 7 , sheet $2 B$; and 8, sheet 2C), and commonly exhibit lacustrine tufa or fossils (Reheis and Miller, 2010). In a few locations, horizontally bedded deeper-water deposits (photo 9, sheet $2 B$ ) of fine sand, silt, and clay are preserved (for example, section M07-11, UTM 11S, easting 551617, northing 3879436 in table 3). Common thin tufa coats on clasts, locally overlying weak buried soils, mark lake-level fluctuations. Ostracodes present in finer sediments. Numerous radiocarbon dates indicate these deposits range in age from $>40,000$ to $\sim 25,000$ cal yr B.P. (table 1; Reheis and Redwine, 2008; Reheis and others, 2010). Unit is correlative with Jefferson's (2003) "member D." Extends as high as 544 masl. Locally subdivided in Afton subbasin into basal unit Q180

Lacustrine deposits, older unit 8 (late Pleistocene) - Well-sorted, well-rounded, tufa-coated gravel, commonly just one stone thick, overlying fan gravel (Qia7) that overlies older lake sediments (Q17). Locally, deposits include beach gravel with steeply dipping foreset beds, $\sim 1 \mathrm{~m}$ thick, with a tufa-coated cobble line at the base. Gravel commonly overlies $\sim 20-50 \mathrm{~cm}$ of poorly sorted green sand and fine gravel with many root casts, probably of marsh or lacustrine origin. Mapped only in Afton area south of Mojave River; elsewhere, shown as Qia7. Tufa from the gravel yielded a U-Th isochron age of $42 \pm 15 \mathrm{ka}$ (table 3, station M06-62B) (J.B. Paces, USGS, written commun., 2010). However, Meek (2000) reported a U-series age of $\sim 80$ ka from the same unit (dated by James Bischoff, USGS) 
Lacustrine deposits, unit 7 (early late Pleistocene and middle Pleistocene) — Lacustrine sediment ranging from fan-delta deposits (Reheis and Miller, 2010) to well-sorted, well to moderately well-rounded beach gravel to sand, silt, and clay (photos 1, 4, 10, 11, and 16). Sand and gravel beds are locally steeply dipping (as much as $25^{\circ}$ ). Laminated to bedded with beds from 1 to $10 \mathrm{~cm}$ thick. Mud has distinct olive green color, and groundwater alteration causes some sandy beds to be bright orange, yellow, or black. Abundant ostracodes throughout fine-grained sediment. Basal gravel clasts typically have thick lacustrine tufa coats (photos 12 and 13). Preliminary U-Th analyses on tufa from base of unit indicate age range of $\sim 75-170 \mathrm{ka}$ (J.B. Paces, USGS, written commun., 2010). In view of stratigraphic position of Q17 below Q18 that has ages of $\sim 25-\geq 40 \mathrm{ka}$, several ${ }^{14} \mathrm{C}$ ages of $\sim 40-50 \mathrm{ka}$ on Anodonta shells from Q17 (table 1, M05-20A, M05-23C, M05-25J, M05-26F) are considered minimum ages likely contaminated by younger carbon. In Afton subbasin, locally subdivided into older (QI7a) and younger (QI7b) units by intervening soil or unconformity. Unit is correlative with upper part of Jefferson's (2003) "Member C." Extends as high as 558 masl in undeformed areas. Preserved total thickness ranges from less than $1 \mathrm{~m}$ to as much as $17 \mathrm{~m}$ (sheet $2 B$, DI section) in Afton subbasin; unit is thickest near modern valley axis

Lacustrine deposits, unit 7b (early late Pleistocene and late middle Pleistocene)—Upper part of unit QI7 where locally subdivided in Afton subbasin. Typically dominated by green mud and sandy mud with local thin interbeds of sand (photos 10,11,14, and 15); locally capped by coarse beach sand. Commonly overlies very weak soil formed on older unit Q17a. Where measured in DI section (sheet $2 B$ ), about $10 \mathrm{~m}$ thick and overlies cross-bedded beach sand instead of soil

Lacustrine deposits, unit 7a (middle Pleistocene) — Lower part of unit Q17 where locally subdivided in Afton subbasin. Typically dominated by medium to fine beach sand with lesser green mud, sandy mud, and gravel (photos 14, 15, and 16). Commonly overlies very weak soil formed on older unit Qia6. Where measured in DI section (sheet $2 B$ ), about $7 \mathrm{~m}$ thick

Lacustrine deposits, unit 6 (middle Pleistocene) —Lacustrine sand, silt, and minor clay. In Afton subbasin, well sorted, well to moderately rounded grains; laminated to bedded with beds from 1 to $10 \mathrm{~cm}$ thick. Near Mojave River, basal sand exhibits long, sweeping, northeast-directed cross-beds (photos 17 and 18) containing rhizoliths that yielded a U-Th age of $173.6 \pm 8.7 \mathrm{ka}$ (section M05-54, sheet $2 C$; J.B. Paces, USGS, written commun., 2010). Sands are locally interbedded with fluvial sand and gravel of unit Qof, and may contain rip-up clasts of green lacustrine sediment (photos 19 and 20). In one location north of river (sheet $2 C$, station M07-159; table 2; photo 20), fine-grained deposits $2.5 \mathrm{~m}$ above unit base contain lenses $0.5-3 \mathrm{~cm}$ thick of white, fine-grained, reworked Manix tephra, chemically correlated to rhyolite in Long Canyon, southern California, dated by ${ }^{40} \mathrm{Ar}{ }^{39} \mathrm{Ar}$ at $184 \pm 4 \mathrm{ka}$ (R.J. Fleck, USGS, written commun., 2010). Extends as high as $\sim 513$ masl. In Cady subbasin, unit commonly contains the Manix tephra west of Manix Wash (outside the map area), extends as high as 541 masl, and is usually included for convenience in unit Q17. In some measured sections (for example, sheet 2A, M08-163, M09-76, M09-29) it is less than $1 \mathrm{~m}$ thick and may contain a bed of fan gravel or coarse sand containing blocks of reworked lake mud (photos 21 and $22),<25 \mathrm{~cm}$ thick, representing sudden draining of lake during QI6 lake rise (sheet 2A, sections M09-58, M09-76). As much as $10 \mathrm{~m}$ thick in Afton subbasin, mostly sand except in upslope positions

Lacustrine deposits, unit 5 (middle Pleistocene) - Lacustrine and alluvial sediment ranging from well-sorted, well to moderately well-rounded beach gravel and well-bedded sand and silt to cross-bedded moderately sorted sandy gravel (photo 23). Below about 530 masl, unit typically grades upward from alluvial at base to lacustrine at top; above 530 masl, sediment in same stratigraphic position is alluvial. Overlain by gravelly alluvial-fan deposits less than $1 \mathrm{~m}$ thick that are oxidized, locally with Bwk horizon preserved (sheet $2 A$, section M08-112). Commonly capped by single line of tufa-coated clasts, which locally represent entire unit (sheet $2 A$, sections M08-110 and M09-29). Found only in Cady subbasin. On sheet 2 only. As much as $6 \mathrm{~m}$ thick

Lacustrine deposits, unit 4 (middle Pleistocene) - Lacustrine sediment ranging from well-sorted, well to moderately well-rounded beach gravel to sand, silt, and clay. Laminated to bedded to massive, with beds $1-10 \mathrm{~cm}$ thick (photos 1 and 23). Abundant ostracodes throughout fine-grained sediment. Tufa-coated cobbles commonly mark base of unit. Overlain by alluvial-fan deposits included in lake unit, less than $1.5 \mathrm{~m}$ thick, locally with weak Bwk horizon preserved (sheet $2 A$, section M08-130) and capped by single line of tufa-coated clasts (section M09-29). Correlated with lake phase QI4 and possibly QI3 in core (the two phases cannot be distinguished with certainty in the map area). Unit QI4 is found only in Cady subbasin; extends at least as high as $532 \mathrm{~m}$. Overlies unit Qalg, and likely interfingers with it. As much as $5 \mathrm{~m}$ thick 


\section{Fluvial Deposits}

Qfmr Active channel of the Mojave River (late Holocene) - Arkosic sand and gravel, mostly subrounded to well rounded. Clasts larger than pebbles are locally reworked from adjacent alluvial fans. Includes active riverbed and adjacent flood-prone overbank areas within the confined channel; equivalent to alluvial-fan deposits mapped as Qyay. Extensively modified by eolian processes, creating small fields of active dunes. Thickness probably less than $10 \mathrm{~m}$

Mojave River fluvial deposits (Holocene and late Pleistocene) - Include strath, cut-fill, and fill-cut terraces and underlying deposits of commonly well-rounded to subrounded, well-sorted, coarse sand to large cobbles and small boulders (photos 24 and 25). In Afton area, clast size, rounding, and lithology largely dependent on composition of underlying fanglomerate. In Cady subbasin and south of Buwalda Ridge, fluvial deposits dominantly arkosic sand and pebble gravel like that of modern river channel. Desert pavement and varnish are moderately developed. Soils typically have Av/Bwk1/Bwk2/2Coxk profiles with stage I+ carbonate morphology (Reheis and Redwine, 2008; carbonate stage morphology of Gile and others, 1966). Based on inset relations with beach barriers and soil development, these terraces are younger than $\sim 25 \mathrm{ka}$, the age of the youngest highstand of Lake Manix; however, differences in ages of terraces of different heights above stream level (ranging from 5 to $50 \mathrm{~m}$ ) cannot be distinguished using relative age criteria (Reheis and Redwine, 2008). Based on surface characteristics and soil development, these deposits are probably correlative with unit Qyao. Thickness from $<10 \mathrm{~cm}$ to $\sim 4 \mathrm{~m}$

Qysl

Young slackwater deposits (Holocene) - Fine-grained deposits associated with valleys incised into fanglomerate of Cave Mountain (unit QTcg) north of river near the west end of Afton Canyon. Deposits include, from bottom to top: (1) sandy alluvium overlain by well-sorted sand interbedded with blocky green mud that is locally burrowed and contains abundant secondary gypsum and other soluble salts; (2) thinly interbedded green mud and laminated fine to medium sand, (3) thinly interbedded, laminated, and ripple cross-bedded sand locally with clay and silt; coarsens upward and intertongues toward adjacent hillslope deposits of coarse alluvial-fan sand and gravel; and (4) locally derived fan gravel. Many beds contain lacustrine ostracodes, apparently reworked from Lake Manix sediments, because they yielded ages ranging from 27,020 310 to $31,500 \pm 420{ }^{14} \mathrm{C}$ yr B.P. (table 1, JR04D-68), in conflict with a luminescence age of about 7,500 yr measured using both infrared stimulated and optically stimulated luminescence techniques (Shannon Mahan, USGS, written commun., 2005; Reheis and Redwine, 2008). Thickness as much as $5 \mathrm{~m}$

Young fluvial deposits (Holocene and late Pleistocene) - Unconsolidated sand and gravel, undifferentiated by source. Laminated to bedded, with 2-3 cm-thick beds that are locally cross-bedded; well to moderately well sorted sand, silt, and pebble to cobble gravel of mixed lithologies and sources. Mapped only in Afton area. Underlies terrace surfaces and includes gravel lags and deposits as much as $\sim 4 \mathrm{~m}$ thick

\section{Qyaf}

Alluvial deposits of paleovalley fill (Holocene and late Pleistocene) - Interbedded tributary and Mojave River fluvial deposits, mudflows, and alluvial-fan deposits. Deposits fill a paleochannel incised into Lake Manix deposits and unit QTcg (described in Reheis and Redwine, 2008) and lap onto adjacent areas. Eroded with no preserved surfaces; inset below Lake Manix deposits. Thickness as much as $25 \mathrm{~m}$ in paleochannel fill

Intermediate fluvial deposits (late Pleistocene) — Interbedded clast-supported fluvial and matrix-supported alluvial beds. Fluvial deposits are $\sim 0.75 \mathrm{~m}$ thick packages of $2 \mathrm{~mm}$ to $1-7 \mathrm{~cm}$-thick beds, locally cross-stratified; well to moderately well-sorted, well to moderately well-rounded, medium to coarse, quartz-rich sand and granule to cobble gravel from extra-local sources. Alluvial deposits are $20-60 \mathrm{~cm}$ thick beds, with poorly to moderately sorted, mostly angular to subrounded, locally derived coarse sand and gravel. Unit contains many buried soils that are mostly reddened and clay rich. Based on soils, these deposits may be more than twice the age of nearby beach and fluvial deposits that are $\leq 25 \mathrm{ka}$ (Reheis and Redwine, 2008). Reworked ostracodes yielded an age of $33,120 \pm 710{ }^{14} \mathrm{C}$ yr B.P. (table 1, JR04CM-87), considered a minimum age. Identified only at two locations in eastern map area in eroded remnants perched on canyon rim north of river (photos 26 and 27), and interpreted to represent discharge from Lake Manix prior to incision of Afton Canyon (Reheis and Redwine, 2008). As much as $6 \mathrm{~m}$ thick

Older fluvial deposits (middle Pleistocene) - Mostly well-bedded, clast-supported fluvial gravel and sand; locally includes chaotically bedded deposits. Thickest outcrops, east of Buwalda Ridge, exposed interbedded sand, pebbly sand, and sandy gravel beds, moderately sorted and indurated, as much as $10 \mathrm{~m}$ thick (sections M07-117, M07-144, sheet 2B, photos 28 and 29). Locally, two units separated by a weak buried soil are preserved (photo 30 ). Sands are thinly bedded and locally cross-bedded, with some beds exhibiting dips up to $15^{\circ}$ northeasterly. Some clasts, especially near base, consist of reworked, indurated blocks of green lake mud 
(photos 30 and 31). Northeasternmost deposits in Afton subbasin overlie playa deposits and include similar but much thinner fluvial gravel ( $<2 \mathrm{~m}$ thick; photos 32 and 33$)$ that overlies several meters of chaotically bedded blocks (as much as $2 \mathrm{~m}$ across) and clasts of semi-indurated green lake mud, silt, and sand mixed with blocks of brown playa mud (sheet $2 B$, section M06-100; photos 33, 34, and 35). Unit is interpreted as a result of deposition by high-energy stream flowing into Afton subbasin after drainage integration due to catastrophic failure of former lake threshold on south side of Buwalda Ridge. Basal chaotic deposits may have been emplaced as a mudflow originating from older lake deposits in the Cady subbasin at least $12 \mathrm{~km}$ upstream

Tqg

Quartz-rich conglomerate (Miocene) — Cobble to boulder conglomerate; locally contains sandy pebble beds. Locally well exposed in steep drainage cuts, best viewed just south of map area (photo 36), where unit fills north-trending paleovalley cut in Jurassic(?) plutonic rocks (unit $\mathrm{Br}$ ). Locally cross-bedded, with beds suggesting northwest-directed flow. Clasts are mainly well rounded to subrounded; clast size increases and rounding decreases toward paleovalley margins. Dominantly composed of flow-banded rhyolite, and granitoids, including meta-diorite, dense gray quartz monzonite (?), and epidotized siliceous dike (?) rocks, with lesser amounts of mafic volcanic clasts. South of map area, locally contains beds of limestone with thin wavy beds $0.5-2 \mathrm{~cm}$ thick. Limestone beds pinch out laterally within about $100 \mathrm{~m}$ and likely represent deposition in spring mounds (photo 37). Mapped as conglomerate unit Tcg by Danehy, E.A., and Collier, J.T., Southern Pacific Company (unpub. data, 1958); overlain sequentially by rhyolite tuff and andesite flow of unit Tvs (photo 38). Crops out only south of Manix fault west of Afton Canyon. Unit Tqg is the most likely source of similar well-rounded clasts found in basal parts of unit QTvg and fanglomerate of Buwalda Ridge. As much as $70 \mathrm{~m}$ thick in paleovalley axis; thins to zero along valley margins

\section{Alluvial-Fan Deposits}

Alluvial-fan deposits are generally similar in grain size and bedding; the following description applies to each alluvial unit described below unless otherwise stated. Gravel, sand, and silt; intermixed and interbedded, moderately sorted to unsorted, moderately to poorly stratified. Clasts commonly pebbles to cobbles, but near range fronts, may be larger than $1 \mathrm{~m}$ in diameter. Beds may be either clast supported (stream-flow deposit) or less commonly, matrix supported (debris-flow deposit). Contain thin lenses of sand and silt

Qya Young alluvial-fan deposits, undivided (Holocene and late Pleistocene)-Alluvial fan and wash deposits. Includes scattered thin mudflow deposits

Qyay Young alluvial-fan deposits, younger subunit (late Holocene) - Active alluvial fans, washes, and low surfaces within washes, $<1 \mathrm{~m}$ above active channel; prone to flooding in large events. No desert pavement or varnish. No to very weak soil development with minor eolian accumulation or weak Av horizons. Includes units Qya1 and Qya2 of Redwine (U.S. Bureau of Reclamation, unpub. data)

Qyao Young alluvial-fan deposits, older subunit (Holocene and late Pleistocene) — Surfaces are mostly abandoned. Moderately well-developed desert pavement over $\sim 75$ percent of surface and moderately developed varnish on clasts. Fans locally grade to or are inset within lacustrine deposits of the last Lake Manix highstand ( $25 \mathrm{ka}$ ). Includes strath terraces along some tributaries. Soils typically Av/B or Bwk or Btjk/Ck or Av/Btjk/ Ck profiles with stage I or I+ carbonate (Gile and others, 1966). Includes units Qya3 and Qya4 of Redwine (U.S. Bureau of Reclamation, unpub. data)

Intermediate alluvial-fan deposits, undivided (early late Pleistocene and middle Pleistocene) - Fan surfaces with well-developed desert pavement over $\sim 80$ percent of surface and well-developed varnish on clasts. Typical soil development: Av/Bwk1/Bwk2/Ck profiles with stage I carbonate (Gile and others, 1966). Depending on location, surfaces can be abandoned, rounded, and incised up to tens of meters or can be partially buried (photos 39 and 40). Where buried, or previously buried and exhumed, deposits are subdivided below on the basis of relations with lake units or other fan units; for example, Qia7 underlies deposits of Q18 and overlies deposits of Q17 (for example, sheet 2D, section M05-26). Stratigraphy is based on correlation with Manix core, located just west of map area, as extrapolated to exposures in Manix Wash; units Qia1-3 represented in that core are not recognized within the map area, but are likely correlative with the upper part of unit Qalg. Units Qia4 and Qia5 are not separately mapped but are shown in some stratigraphic sections of sheet 2 . In the Afton subbasin, intervening fan deposits are sufficiently thick and extensive that they can be mapped, but are usually grouped with underlying lake units for convenience (for example, Qia7/Q17). Separate mapping is often impractical in areas where fan deposits are less than $50 \mathrm{~cm}$ thick or erosion has removed fan deposits. Fan units older than Qia6 in the Cady subbasin are mapped and described together with the underlying lake unit; fan units older than Qia6 in the Afton subbasin are mapped as Qia (undivided). Thickness ranges from $25 \mathrm{~cm}$ to $>5 \mathrm{~m}$ 
Qia7 Alluvial-fan deposits, unit 7 (late Pleistocene)-Surfaces with well-developed desert pavement and varnish. West of the Lake Manix threshold, unit was deposited between lacustrine units Q18 and Q17 deposits during lake regression (photo 6). Locally, clasts in unit Qia7, especially at top, are coated with lacustrine tufa. Qia7 deposits have been buried and subsequently exhumed for varying amounts of time since deposition. As a result, surfaces and soils are commonly less developed than would be typical of a fan of equivalent age that remained at the surface since deposition

Alluvial-fan deposits, unit 6 (middle Pleistocene) —Alluvial fan sediment deposited between units QI7 and Q16 during lake regression (photo 22). Oxidized at top, locally has weak Bw horizon preserved. Generally mapped together with underlying unit Q16 in Afton subbasin north of the Mojave River. Where unit Q16 was not deposited, generally above $510 \mathrm{~m}$ elevation, unit is included with alluvial sequence (Qia) that predates arrival of Lake Manix in Afton subbasin. Unit is not separately mapped in Cady subbasin, but interval is locally represented there by oxidized fan gravel, sometimes containing reworked lake sediment (for example, sheet $2 A$, sections M09-58 and M09-76). Typically $<1 \mathrm{~m}$ thick, locally represented only by disconformity or weathering zone

Alluvial-fan deposits, unit 5 (middle Pleistocene) — Alluvial fan sediment deposited between units QI6 and Q15 during lake regression. Oxidized at top, locally has weak Bw horizon preserved. Unit occurs only in Cady subbasin but is not separately mapped; locally shown in measured sections (for example, sheet $2 A$, section M09-58). Typically $<1 \mathrm{~m}$ thick, locally represented only by disconformity or weathering zone. Sheet 2 only

\section{Qia4}

Alluvial-fan deposits, unit 4 (middle Pleistocene) - Alluvial fan sediment deposited between units Q15 and Q14 during lake regression. Oxidized at top, locally has weak Bw horizon preserved. Unit occurs only in Cady subbasin but is not separately mapped; locally shown in measured sections (for example, sheet $2 \mathrm{~A}$, sections M08-60 and M08-130). Typically $<1 \mathrm{~m}$ thick, locally represented only by disconformity or weathering zone. Sheet 2 only

Older alluvial-fan deposits (middle and early Pleistocene) - Alluvial fans with poorly preserved, rounded and eroded surfaces. Locally, thick carbonate soils with stage III or greater morphology are exposed. Moderately developed and degraded desert pavement and varnish. Age is unknown, but based on poor preservation and apparently more developed soils, these deposits are inferred to be older than Qia fans. Mapped only in Afton subbasin

Arkosic-lithic fanglomerate (middle and early Pleistocene) - Pebble to cobble fanglomerate with clasts composed of wide range of plutonic, volcanic, and minor sedimentary rock types; sand fraction dominantly arkosic in composition (photos 4, 14, 40, 41, and 42). Unit has many weak to moderate paleosols throughout consisting of $\mathrm{Bk}$ and $\mathrm{Bw}$ or Bt horizons. Weakly to moderately indurated. West and south of Buwalda Ridge, this unit is much finer grained than areas to the east, and contains massive silt beds locally interbedded with sandy pebble gravel. Near Manix Wash, Nagy and Murray $(1991,1996)$ mapped unit as upper part of Mojave River formation; however, to the east unit is coarser and overlies unit Qmr on an erosional and locally a slightly angular unconformity (photo 42). At one site north of the river, a tuffaceous bed marks an erosional contact with underlying finer-grained deposits of unit Qmr. Sample M10-94 (table 2) yielded possible correlations with 0.76-Ma Bishop ash and 1.2-0.78-Ma upper Glass Mountain ash beds (Sarna-Wojcicki and others, 2005), suggesting that at this site unit may be late Matuyama or early Brunhes polarity chronozones in age as proposed by Pluhar and others (1991). In one outcrop on the south side of the river (table 2; sheet 2B, station M10-90 in sections measured at stations M07-128 and M08-55), unit Qmr contains the 2.1-Ma Huckleberry Ridge ash, as also reported nearby (Nagy and Murray, 1991; Sarna-Wojcicki and others, 1984, 2005). Above this ash bed, unit grades up into gravelly unit Qalg with no unconformity, and this in turn becomes increasingly volcaniclastic upward through a 10-m interval to become unit Qvg. Thus, unit Qalg is here considered an alluvial facies of upper playa unit Qmr. Generally undeformed except adjacent to faults. Thickness at least $10 \mathrm{~m}$

Younger volcanic fanglomerate (middle and early Pleistocene) - Coarse fanglomerate derived almost entirely from rocks exposed in the Cady Mountains, including a variety of volcanic lithologies, mainly basalt, rhyolite, andesite(?), and tuff. Beds mostly $0.5-2 \mathrm{~m}$ thick; clasts rounded to subrounded, locally subangular, mostly sand to small cobbles with grayish brown matrix. Unit has weakly to moderately developed paleosols throughout consisting of Bk and Bw or Bt horizons. Weakly to moderately indurated. Previously termed the "gray conglomerate" by Ellsworth (1932) and Meek (1989b). Widespread on south side of river and directly underlies deposits of Lake Manix in both subbasins; also mapped in limited area on north side of river, where clasts are derived from Buwalda Ridge. In Afton subbasin, unconformably overlies unit QTcg (photos 43 
and 44); in Cady subbasin, conformably overlies unit Qmr or Qalg (photo 45) and locally interfingers with lacustrine units QI4 and Q15. Nagy and Murray (1996) and Meek and Battles (1991) argued that the appearance of Cady Mountain volcanic rocks in fanglomerates marks the time of onset of a compressional tectonic regime that caused uplift of the Cady Mountains. Based on magnetostratigraphy within the Cady subbasin, this change occurred 1.1-0.78 Ma (Nagy and Murray, 1996). However, older volcaniclastic fanglomerate (QTvg) underlies unit Qvg in the Afton subbasin and the fanglomerate of Buwalda Ridge (Tbrg) is also largely derived from rocks in the Cady Mountains, suggesting earlier uplift. Generally undeformed except adjacent to faults. Thickness highly variable, locally as much as $30 \mathrm{~m}$

Fanglomerate, undifferentiated (early Pleistocene? and Pliocene?)—Fanglomerate. May include deposits elsewhere mapped as units QTvg, Qoa, and Tertiary sediment considered by Danehy, E.A., and Collier, J.T., Southern Pacific Company (unpub. data, 1958) as possibly equivalent to the informally named Yermo formation. Mapped only south of Mojave River near head of Afton Canyon

Older arkosic-lithic fanglomerate (early Pleistocene? and Pliocene) - Sandy pebble to cobble fanglomerate with clasts composed of wide range of plutonic, volcanic, and minor sedimentary rock types and sand fraction dominantly arkosic in composition. Unit has weak to moderate paleosols throughout consisting of Bk and $\mathrm{Bw}$ or Bt horizons. Moderately to strongly indurated. Along northeastern margin of Buwalda Ridge, unit appears to be conformable on unit Tbrg and contains higher proportion of mafic volcanic clasts than elsewhere. Outcrops generally are tilted from $5-10^{\circ}$ even distant from faults, in contrast to unit Qalg. Considered equivalent to part of south Alvord gravel of Miller and others (2011). Thickness unknown but may be more than $100 \mathrm{~m}$

Fanglomerate of Cave Mountain (early Pleistocene? and Pliocene) - Fanglomerate composed almost entirely of felsic and mafic plutonic rocks, commonly with clasts of iron-rich ore. Well cemented, with beds $1-5 \mathrm{~m}$ thick; clayey to sandy matrix with angular to subrounded clasts as much as $2 \mathrm{~m}$ in diameter. Unit has many well-developed buried soils with many, prominent clay films in Bt horizons that can be meters thick, and stage $\mathrm{V}$ and greater carbonate horizons that can be meters thick and that often create waterfalls in smaller drainages. Unit has a pink color from Bt horizons and common felsic granitic rocks. Previously termed the "brown conglomerate" by Ellsworth (1932) and Meek (1990). Unit is sourced from Cave Mountain to northeast and thins to south, extending slightly south of Mojave River (photos 43 and 44). Unit is faulted near the eastern Lake Manix threshold and is not identified farther east. North of river, unit overlain by basal Lake Manix deposits (units QI6 or Q17). South of river, overlain by unit Qvg. At one locality north of the river (table 2, M07-145) just below contact with unit Q17, QTcg contains a tephra. Its chemical composition matches a range of late Pliocene and Quaternary samples from diverse study areas, but may be most closely matched with the 2.4-Ma Ishi Tuff, a member of the Tuscan Formation. Estimated thickness at least $60 \mathrm{~m}$

Older volcanic fanglomerate (early Pleistocene? and Pliocene?) - Coarse fanglomerate composed almost entirely of Cady Mountain lithologies, mainly basalt, andesite, biotite rhyolite, and tuff, but in some beds as much as 50 percent granitic clasts. Upper part of exposed section contains clasts similar to unit Tgg, including granite with large pink feldspar phenocrysts, biotite granite, and meta-diorite; middle part contains no granitic clasts; and lowest part of section contains as much as 20 percent rounded, gray flow-banded rhyolite, gray quartz monzonite (?), and siliceous dike rocks similar to those in units Tqg and Tbrg (photo 46). Compared to unit Qvg, QTvg is generally finer grained (especially the dominantly mafic beds), more thinly bedded, and more indurated. Locally contains lenses of reworked eolian sand (photo 47). Well exposed along the Manix fault south of river in Afton subbasin, where it is in fault contact with unit Tgg. Commonly tilted, with dips up to $45^{\circ}$, and typically underlies unit Qvg with angular unconformity. Unconformably overlies unit Tvs (photo 48). Correlative at least in part with unit Tbrg. Total thickness unknown, but at least $75 \mathrm{~m}$

Fanglomerate of Buwalda Ridge (Pliocene) - Cobble to boulder fanglomerate composed entirely of Cady Mountains lithologies; forms prominent elongate ridge (Buwalda Ridge; fig. 2, photos 1 and 49) separating the Cady and Afton subbasins on north side of Mojave River. Bounded on north and south and internally cut by strands of the Manix fault. Moderately indurated. Basal part of outcrop resembles a megabreccia composed of matrix-supported, angular to well-rounded, cobbles to large boulders, lacking visible bedding, as much as $35 \mathrm{~m}$ thick. Clasts mainly composed of andesite, andesitic tuff, and lesser basalt; as much as 25 percent of total mainly composed of granitoids, including meta-diorite, dense gray quartz monzonite (?), and epidotized siliceous dike rocks. This breccia may have been deposited as a landslide originating in older alluvial deposits partly sourced from plutonic rocks exposed mainly south of map area of unit Tqg. Likely correlative with basal 
part of unit QTvg. Upward in section and westward along Buwalda Ridge, grades into coarsely bedded alluvialfan deposits, with clasts generally smaller in caliber, poorly to moderately sorted and rounded, and only a few percent granitoid rocks compared to lower part (photo 50). Along the northeastern margin of Buwalda Ridge, the unit locally contains finer-grained fan deposits that are intercalated with red, matrix-rich, carbonate-bearing paleosols and that appear to grade up into arkosic unit QTalg. In one area on eastern edge of Buwalda Ridge, unit grades up into reddish distal-fan and playa deposits of unit Ta. Overlain in angular unconformity by unit Qalg. Near top of outcrop on the east end of Buwalda Ridge, contains two lenses of tephra identified as 3.4-Ma tuff of Mesquite Springs (table 2, M07-101A and B; photos 50 and 51). Commonly tilted and strongly sheared adjacent to faults. Estimated thickness at least $120 \mathrm{~m}$

Tgg Granitic fanglomerate (Pliocene and late Miocene?) - Pebble to boulder fanglomerate. Clasts are mainly composed of granite with large pink feldspar phenocrysts, lesser foliated biotite granite, diorite, andesite, rhyolite, and rhyolite tuff; coarsely bedded with sandy matrix and clast sizes ranging from pebbles to boulders. Unit lacks paleosols and overall is light gray in color (photo 52). Base of unit, where exposed on western flank adjacent to Manix fault, overlies distinctive andesite tuff, pinkish in color, probably part of unit Tvs. Tuff is overlain by fanglomerate at least $100 \mathrm{~m}$ thick that at base is composed entirely of clasts of same tuff (photo 53), and becomes mixed with other volcanic and granitic clasts upward. Basal unit dips vertical adjacent to fault; dips decrease upward through section to as low as $\sim 12^{\circ}$. Unit displaced left-laterally at least $7 \mathrm{~km}$ along Manix fault (Meek, 1990). Total thickness at least $400 \mathrm{~m}$ as estimated from topographic map

\section{Playa and Distal-Fan Deposits}

Playa and distal-fan deposits (middle Pleistocene) - Mud, silt, sand, and lesser fine gravel in massive, poorly sorted, matrix supported beds (photos 34 and 54). Locally includes moderately bedded, poorly sorted alluvial deposits $20-50 \mathrm{~cm}$ thick. Deposited by low-gradient streams, playas, and small wetlands in Afton subbasin when internally drained, prior to deposition of units Qof and Q16 that record the influx of Lake Manix (sheet 2B, section M06-70). Interfingers with unit Qalg. Thickness at least $10 \mathrm{~m}$

Mojave River formation (informal) of Nagy and Murray (1991) (middle and early Pleistocene; previously interpreted as Pliocene) - Mud, silt, sand, and fine gravel; moderately indurated. Described in detail by Nagy and Murray (1991). Most of unit is massive to faintly cross-bedded silt and fine sand interbedded with lesser gypsiferous mud and minor thin gravel beds (photo 55). Approximately the upper third of unit is dominantly coarse-grained arkosic sand and pebbly sand (in part mapped separately as unit Qalg) containing numerous buried soils; this facies varies in thickness depending on distance from basin center. Uppermost arkosic deposits are interbedded with, and interpreted to grade upward into, unit Qvg. A tephra layer in lower part of unit Qmr was previously correlated with 2.09-Ma Huckleberry Ridge Tuff (photo 56) and two slightly younger tephra were correlated with the tuff of Emigrant Pass and lower tuffs of Glass Mountain (Sarna-Wojcicki and others, 1984, 2005; Nagy and Murray, 1991; Pluhar and others, 1991). At one new station, M08-164B, a tephra layer lies $1.1 \mathrm{~m}$ above the Huckleberry Ridge ash (table 2, M08-164) and is correlated with the $\sim 2.0$ Ma tuff of Emigrant Pass. Another newly discovered tephra layer (sheet $2 B$, M07-128, and a sample from station M08-164, about $2.5 \mathrm{~km}$ to the southwest on sheet 1; table 2) lies $\sim 3 \mathrm{~m}$ below the Huckleberry Ridge ash and is correlated with one of the tuffs of Blind Spring Valley, 2.2-2.1 Ma (photos 57 and 58). Unit is interpreted to represent deposition by low-gradient streams and playas in internally drained basin. Thickness at least $80 \mathrm{~m}$

Playa and distal alluvial-fan deposits (Pliocene) - Massive mud, silt, sand, and fine gravel; strongly indurated. Reddish-brown mud beds typically contain single lines of clasts or floating clasts (photo 59). Clast composition grades upward from dominantly mafic volcanic rocks with smaller silicic volcanic component to dominantly arkosic; matrix is reddish, unlike Mojave River formation. Interpreted as playa and distal alluvial fan deposits. On eastern margin of Buwalda Ridge, gravelly distal fan deposits overlie reddish carbonate-bearing paleosols and matrix-rich debris flows of upper unit Tbrg. Muds are thickest along south side of river (for example, sheet $2 B$, section M07-144), probably indicating former basin axis. Depositional setting similar to that of Mojave River formation, but separate from it in time and space. Mapped only east of Buwalda Ridge in vicinity of Manix fault. Likely correlative in part with unit QTalg. Minimum thickness $6 \mathrm{~m}$ but probably much thicker 


\section{Eolian and Mixed Eolian-Alluvial Deposits}

Qye Young eolian deposits (Holocene and late Pleistocene)_Moderately sorted arkosic sand, massive to thinly bedded. Locally contains shell fragments and ostracodes reworked from Lake Manix beds. Eolian deposits forming sand sheets, sand ramps, and dunes. Locally intermixed and interbedded with colluvial deposits. Mapped separately only where thickness exceeds $\sim 1 \mathrm{~m}$

Qyea Young mixed eolian and alluvial-fan deposits, undivided (Holocene and late Pleistocene) - Interbedded poorly to moderately sorted sand and sandy gravel. Sand beds are arkosic, massive to thinly bedded, and interpreted as eolian deposits sourced primarily from the Mojave River. Gravel beds same as in unit Qya. Mapped only in Afton area where eolian influence is pervasive. Locally subdivided into:

Young mixed eolian and alluvial-fan deposits, younger subunit (late Holocene) - Interbedded poorly to moderately sorted sand and sandy gravel. Includes active channels and low surfaces $<1 \mathrm{~m}$ above active channels; prone to flooding in large events. No desert pavement or varnish. Equivalent to unit Qyay

Young mixed eolian and alluvial-fan deposits, older subunit (Holocene and late Pleistocene)-Interbedded poorly to moderately sorted sand and sandy gravel. Moderately well-developed desert pavement over $\sim 75$ percent of surface and moderately developed varnish. Fans locally either grade to or are inset within lacustrine deposits of the last Lake Manix highstand $\sim 20{ }^{14} \mathrm{C} \mathrm{ka}$. Equivalent to unit Qyao

\section{Qiea}

Older mixed eolian and alluvial-fan deposits (late and middle Pleistocene) - Interbedded poorly to moderately sorted sand and sandy gravel (photos 60 and 61). Arkosic sand beds are massive to thinly bedded. Gravel beds are generally clast supported with angular to subangular clasts. Interpreted as interbedded eolian, reworked eolian, and alluvial-fan deposits. Contain buried soils; weakly to moderately indurated

\section{Bedrock Units}

Volcanic and sedimentary rocks, undivided (Miocene)_-Volcanic rocks and volcaniclastic sediments. Unit includes basalt, andesite, and dacite flows and intrusive rocks in the southwestern part of the map area (Vanderpool, J.S., and Danehy, E.A., Southern Pacific Company Land Dept., unpub. data, 1959). In the northeastern part of the area, unit includes rhyolite, rhyolite tuffs, andesite, andesite tuff, pumiceous tuff, tuffaceous sandstone, siltstone, and mudstone, basalt, andesitic basalt, and volcaniclastic deposits, interbedded with reddish brown conglomerates and one minor bed of limestone. Mapped by Danehy, E.A., and Collier, J.T., Southern Pacific Company (unpub. data, 1958) and Moseley (1978) and defined as Hector Formation by Moseley (1978) and Woodburne and others (1974). Age range of Hector Formation 23-16 Ma (MacFadden and others, 1990; Hillhouse and others, 2010) diorite, as mapped by Danehy, E.A., and Collier, J.T., Southern Pacific Company (unpub. data, 1958). Locally sheared and metamorphosed 


\section{Acknowledgments}

James B. Paces, USGS, provided the uranium-series ages. Norman Meek, California State University, San Bernardino, introduced us to Afton basin stratigraphy and his interpretations of Lake Manix history. C.G. Oviatt, Kansas State University, Manhattan, and D.M. Miller, USGS, made additional stratigraphic observations. The authors would also like to thank David M. Miller and Emily M. Taylor (USGS) for their peer reviews of this work.

\section{References Cited}

Bedford, D.R., 2003, Surficial and bedrock geologic map database of the Kelso 7.5 minute quadrangle, San Bernardino County, California: U.S. Geological Survey Open-File Report 03-501, 33 p., scale 1:24,000.

Blackwelder, Eliot, and Ellsworth, E.W., 1936, Pleistocene lakes of the Afton basin, California: American Journal of Science, v. 231, p. 453-463.

Bortugno, E.J., and Spittler, T.E., 1986, Geologic map of California, San Bernardino sheet: Department of Conservation, California Division of Mines and Geology, scale 1:250,000.

Byers, F.M., Jr. 1960, Geology of the Alvord Mountain quadrangle, San Bernardino County, California: U.S. Geological Survey Bulletin 1089-A, 71 p.

Cox, B.F., Hillhouse, J.W., and Owen, L.A., 2003, Pliocene and Pleistocene evolution of the Mojave River, and associated tectonic development of the Transverse Ranges and Mojave Desert, based on borehole stratigraphy studies and mapping of landforms and sediments near Victorville, California, in Enzel, Yehouda, Wells, S.G., and Lancaster, Nicholas, eds., Paleoenvironments and paleohydrology of the Mojave and southern Great Basin Deserts: Boulder, Colo., Geological Society of America Special Paper 368, p. $1-42$.

Dibblee, T.W., Jr., 1968, Geology of the Opal Mountain and Fremont Peak quadrangles, California: California Division of Mines and Geology Bulletin, v. 188, 64 p.

Dudash, S.L., 2006, Preliminary surficial geologic map of a Calico Mountains piedmont and part of Coyote Lake, Mojave Desert, San Bernardino County, California: U.S. Geological Survey Open-File Report 2006-1090, 44 p., scale 1:24,000.

Ellsworth, E.W., 1932, Physiographic History of the Afton Basin: Stanford, Calif., Ph.D. dissertation, Stanford University, 98 p.
Enzel, Yehouda, Wells, S.G., and Lancaster, Nicholas, 2003, Late Pleistocene lakes along the Mojave River, southeast California, in Enzel, Yehouda, Wells, S.G., and Lancaster, Nicholas, eds., Paleoenvironments and paleohydrology of the Mojave and southern Great Basin Deserts: Boulder, Colo., Geological Society of America Special Paper 368, p. 61-77.

Fillmore, R.P., 1993, Sedimentation and extensional basin evolution in a Miocene metamorphic core complex setting, Alvord Mountain, central Mojave Desert, California, USA: Sedimentology, v. 40, p. 721-742.

Geological Society of America, 2012, GSA Geologic time scale, ver. 4.0: Boulder, Colo., The Geological Society of America, Inc.

Gile, L.H., Peterson, F.F., and Grossman, R.B., 1966, Morphological and genetic sequences of carbonate accumulation in desert soils: Soil Science, v. 101, p. 347-360.

Hillhouse, J.W., Miller, D.M ., and Turrin, B.D., 2010, \&RU relation of the Miocene Peach Springs Tuff with the JHI magnetic polarity time scale, in Reynolds, R.E., and 0 ICOHU D.M., eds., Overboard in the Mojave -20 Million $<$ HWV of Lakes and Wetlands, Abstracts of Proceedings: $=] \backslash][\square$ Calif., Desert Studies Consortium, California State[8 QIYHU sity Fullerton, 2010 Desert Symposium, p. 105-121, http:// biology.fullerton.edu/facilities/dsc/pdf/2010Overboard.pdf.

Jefferson, G.T., 2003, Stratigraphy and paleontology of the middle to late Pleistocene Manix Formation, and paleoenvironments of the central Mojave River, southern California, in Enzel, Yehouda, Wells, S,G., and Lancaster, Nicholas, eds., Paleoenvironments and Paleohydrology of the Mojave and Southern Great Basin Deserts: Geological Society of America Special Paper 368, p. 43-60.

Lichvar, R.W., and Finnegan, D.C., 2004, Wetlands Regulatory Assistance Program (WRAP): U.S. Army Corps of Engineers.

Lisiecki, L.E., and Raymo, M.E., 2005, A Pliocene-Pleistocene stack of 57 globally distributed benthic $\delta^{18} \mathrm{O}$ records: Paleoceanography, v. 20, no. PA1003, 17 p.

MacFadden, B.J., Woodburne, M.O., and Opdyke, N.D., 1990, Paleomagnetism and Neogene clockwise rotation of the northern Cady Mountains, Mojave Desert of southern California: Journal of Geophysical Research, v. 95, p. 4597-4608.

Meek, N.C., 1989a, Geomorphic and hydrologic implications of the rapid incision of Afton Canyon, Mojave Desert, California: Geology, v. 17, p. 7-10.

Meek N.C., 1989b, Physiographic history of the Afton basin, revisited, in Reynolds, R.E., ed., The west-central Mojave Desert - Quaternary studies between Kramer and Afton Canyon: Redlands, Calif., San Bernardino County Museum Association Special Publication, p.78-83. 
Meek, N.C., 1990, Late Quaternary geochronology and geomorphology of the Manix basin, San Bernardino County, California: Los Angeles, Calif., Ph.D. dissertation, University of California, $212 \mathrm{p}$.

Meek, N.C., 1994, The stratigraphy and geomorphology of Coyote basin, in Reynolds, Jennifer, compiler, Calico, Coyote Basin \& Lake Havasu Giants: Redlands, Calif., San Bernardino County Museum Association Quarterly, v. 41 , no. 3, p. 5-13.

Meek, N.C., 2000, The late Wisconsinan history of the Afton Canyon area, Mojave Desert, California, in Reynolds, R.E., and Reynolds, Jennifer, eds., Empty basins, vanished lakes, the year 2000 Desert Symposium Field Guide: Redlands, Calif., San Bernardino County Museum Association Quarterly, v. 47, no. 2, p. 32-34.

Meek, N.C., 2004, Mojave River history from an upstream perspective, in Reynolds, R.E., ed., Breaking Up-The 2004 Desert Symposium Field Trip and Abstracts: Fullerton, Calif., California State University Fullerton, Desert Studies Consortium, p. 41-49.

Meek N.C., and Battles, D.A., 1991, Displacement along the Manix fault: California Geology, v. 44, p. 33-38.

Miller, D.M., Bedford, D.R, Hughson, D.L., McDonald, E.V., Robinson, S.E., and Schmidt, K.M., 2009, Mapping Mojave Desert ecosystem properties with surficial geology, in Webb, R.H., Fenstermaker, L.F., Heaton, J.S., Hughson, D.L., McDonald, E.V., and Miller, D.M., eds., The Mojave Desert-Ecosystem processes and sustainability: Reno, Nev., University of Nevada Press, p. 225-251.

Miller, D.M., Dudash, S.L., and McGeehin, J.P., 2009, Chronology of pluvial Lake Coyote, California, and implications for 25,000 to 10,000 cal. yr. B.P. Mojave River paleohydrology [abs.] in Pacific Climate Workshop, Pacific Grove, Calif., April 19-22, 2009: U.S. Department of Agriculture Pacific Southwest Research Station, Pacific Climate Workshop (PACLIM) 2009.

Miller, D.M., and McGeehin, J.P., 2007, Depositional environment and radiocarbon chronology of the upper Lake Manix deposits, Mojave Desert, California [abs.]: Geological Society of America Abstracts with Programs, v. 39, no. 6, p. 271.

Miller, D.M., Reheis, M.C., Wan, Elmira, Wahl, D.B., and Olson, Holly, 2011, Pliocene and early Pleistocene paleography of the Coyote Lake and Alvord Mountain area, Mojave Desert, California, in Reynolds, R.E., ed., The incredible shrinking Pliocene and Abstracts of Proceedings, the 2011 Desert Symposium, April 2011: California State University Fullerton, Desert Studies Consortium, p. 53-67, http://biology:fullerton. edu/facilites/dsc/pdf/2011shrinkingpliocene.pdf.

Morton, D.M., and Miller, F.K., 2006, Geologic map of the San Bernardino and Santa Ana 30' $\times 60^{\prime}$ quadrangles, California: U.S. Geological Survey Open-File Report 2006-1217, scale 1:100,000.
Moseley, C.G., 1978, The geology of a portion of the northern Cady Mountains, Mojave Desert, California: Riverside, Calif., M.S. thesis, University of California Riverside, $131 \mathrm{p}$.

Nagy, E.A. and Murray, Bruce, 1991, Stratigraphy and intrabasin correlation of the Mojave River formation, central Mojave Desert, California, in Reynolds, Jennifer, compiler, The Mojave River formation, Manix basin, CaliforniaStratigraphy, correlation, magnetostratigraphy, and rotation, Abstracts of Proceedings 1991, Mojave Desert Research Symposium: Redlands, Calif., San Bernardino County Museum Quarterly, v. 38, no. 2, p. 5-30.

Nagy, E.A. and Murray, Bruce, 1996, Plio-Pleistocene deposits adjacent to the Manix fault-Implications for the history of the Mojave River and Transverse Ranges uplift: Sedimentary Geology, v. 103, p. 9-21.

Oviatt, C.G., Reheis, M.C., Miller, D.M., and Lund, S.P., 2007, Stratigraphy of Lake Manix beds in the Manix subbasin, Mojave Desert, CA [abs.]: Geological Society of America Abstracts with Programs, v. 39, no. 6, p. 271.

Pluhar, C.J., Kirschvink, J.L., and Adams, R.W., 1991, Magnetostratigraphy and clockwise rotation of the Plio-Pleistocene Mojave River formation, central Mojave Desert, California, in Reynolds, Jennifer, compiler, The Mojave River formation, Manix basin, California - Stratigraphy, correlation, magnetostratigraphy, and rotation, Abstracts of Proceedings 1991, Mojave Desert Research Symposium: Redlands, Calif., San Bernardino County Museum Quarterly, Redlands, California, v. 38, no. 2, p. 31-42.

Reheis, M.C., Bright, Jordon, Lund, S.P., Miller, D.M., Skipp, Gary, and Fleck, R.J., 2012, A half-million-year record of paleoclimate from the Lake Manix Core, Mojave Desert, California: Palaeogeography, Palaeoclimatology, Palaeoecology, v. 365-366, p. 11-37.

Reheis, M.C., and Miller, D.M., 2010, Environments of nearshore lacustrine deposition in the Pleistocene Lake Manix basin, south-central California, in Reynolds, R.E., and Miller, D.M., eds., Overboard in the Mojave-20 Million Years of Lakes and Wetlands, Abstracts of Proceedings, 2010 Desert Symposium: Zzyzx, Calif., Desert Studies Consortium, California State University Fullerton, 2010 Desert Symposium, p. 24-37, http://biology:fullerton.edu/ facilities/dsc/pdf/2010Overboard.pdf.

Reheis, M.C., Miller, D.M., and McGeehin, J.P., 2010, Late Pleistocene shoreline fluctuations of Lake Manix, Mojave Desert-Paleoclimate implications [abs.]: Geological Society of America Abstracts with Programs, v. 42, no. 4, p. 53.

Reheis, M.C., Miller, D.M., and Redwine, J.R, 2007, Quaternary stratigraphy, drainage-basin development, and geomorphology of the Lake Manix basin, Mojave DesertGuidebook for Fall Field Trip, Friends of the Pleistocene, Pacific Cell, October 4-7, 2007: U.S. Geological Survey Open-File Report 2007-1281, 31 p. 
Reheis, M.C., and Redwine, J.R., 2008, Lake Manix shorelines and Afton Canyon terraces-Implications for incision of Afton Canyon, in Reheis, M.C., Hershler, R., and Miller, D., eds., Late Cenozoic Drainage History of the Southwestern Great Basin and Lower Colorado River Region, Geologic and Biotic Perspectives: Geological Society of America Special Paper 439, p. 227-259.

Reynolds, R.E., and Reynolds, R.L., 1985, Late Pleistocene faunas from Daggett and Yermo, San Bernardino County, California, in Reynolds, R.E., ed., Cajon Pass to Manix Lake-Geological investigations along Interstate 15: Redlands, Calif., San Bernardino County Museum Association Special Publication, p. 175-191.

Sarna-Wojcicki, A.M., Bowman, H.R., Meyer, C.E., Russell, P.C., Woodward, M.J., McCoy, Gail, Rowe, J.J., Jr., Baedecker, P.A., Asaro, Frank, and Michael, Helen, 1984, Chemical analyses, correlations, and ages of upper Pliocene and Pleistocene ash layers of east-central and southern California: U.S. Geological Survey Professional Paper 1293, 40 p.
Sarna-Wojcicki, A.M., Reheis, M.C., Pringle, M.S., Fleck, R.J., Burbank, Doug, Meyer, C.E., Slate, J.L., Wan, Elmira, Budahn, J.R., Troxel, Bennie, and Walker, J.P., 2005, Tephra layers of Blind Spring Valley and related upper Pliocene and Pleistocene tephra layers, California, Nevada, and Utah-Isotopic ages, correlation, and magnetostratigraphy: U.S. Geological Survey Professional Paper 1701, 63 p.

Singleton, J.S., and Gans, P.B., 2008, Structural and stratigraphic evolution of the Calico Mountains-Implications for early Miocene extension and Neogene transpression in the central Mojave Desert, California: Geosphere, v. 4, p. 459-479.

Soil Survey Staff, 1999, Soil taxonomy-A basic system of soil classification for making and interpreting soil surveys ( $2 \mathrm{~d}$ ed.): U.S. Department of Agriculture Handbook 436, $869 \mathrm{p}$.

Woodburne, M.O., Tedford, R.H., Stevens, M.S., and Taylor, B.E., 1974, Early Miocene mammalian faunas, Mojave Desert, California: Journal of Paleontology, v. 48, p. 65-76. 



\section{Appendix. Captions for Selected Photographs of Pleistocene Lake Manix Map Area}

Note: Station and photo index numbers are keyed to field notebooks and all stations are not necessarily shown on map.

Photo 1. View northeast from bluffs north of Mojave River looking across Manix Wash to Buwalda Ridge. Interbedded lacustrine and alluvial beds of the informally defined Manix formation in foreground. Photo point southeast of The Knob. Qye, eolian and alluvialfan deposits; Qmr, Mojave River formation; Tbrg, fanglomerate of Buwalda Ridge. Photo courtesy of Charles G. Oviatt, Kansas State University, 2006 (sheet 1).

Photo 2. Exposure of 184-ka Manix tephra in unit Q16, Afton subbasin, station M07-159 near Dunn wash (photo index number 07-560).

Photo 3. Panorama looking west from eastern margin of Afton subbasin, showing interbedded lake and alluvial-fan units overlying unit QTcg. To right of Shoreline hill, view extends across Mojave River to Manix fault (assembled from photo index numbers 07-306-307).

Photo 4. View northwest of eastern margin of Buwalda Ridge, showing lake beds overlying unit Qalg. Manix fault trace lies just behind the crest of the Q18 outcrop. (photo index number 08-79)

Photo 5. Anodonta and gastropod shells in unit Q18, northeast side of Manix Wash in Cady subbasin, station M08-113 (table 1; photo index number 08-368).

Photo 6. Nearshore sand and gravel of unit Q18 overlying thin Qia7 and greenish muds of unit Q17. West side of North Afton beach ridge, Afton subbasin, station M05-26 (sheet 2D; photo index number 05-304).

Photo 7. Sand and gravel of unit Ql8 deposited in active alluvial-fan interface setting. Outcrop contains several dated shell beds; sample M09-6A (table 1) taken a few $\mathrm{cm}$ to right of shovel head. 50-cm shovel for scale. Railroad cut southwest of Dunn, Afton subbasin, station M09-6 (sheet 2B; photo index number 09-107).

Photo 8. Sand and gravel of unit Q18 deposited in active alluvial-fan interface setting. Outcrop contains several beds separated by tufa-coated clasts (white streaks) representing lake transgressions and a buried soil (reddish), as well as dated shells (M05-19I, table 1). Note backset and foreset beds forming beach barrier in gravel bed above rod top. 1-m rod for scale. Borrow pit in Dunn wash, Afton subbasin, station M05-19 (sheet 2C; photo index number 05-117).

Photo 9. Interbedded sand and sandy green mud of unit Q18. Contains lacustrine ostracodes and a dated gastropod bed at top (sample M10-3A, table 1). 50-cm shovel for scale; orange flag at base marks contact with unit Qia7 below. Railroad cut southwest of Dunn, Afton subbasin, station M07-62 (sheet 2B, photo index number 07-88).

Photo 10. View to northwest of green muds and thin interbedded sands (marked by steps) of unit Q17. Dunn "island" outcrop in Afton subbasin near Dunn (stations DI1-4, sheet 2B). Total thickness about $17 \mathrm{~m}$; contains abundant ostracodes and fish bones (Reheis and others, 2012; photo index number 06-178).

Photo 11. Units Q18, Q17, and QI6 exposed on south side of Mojave River, Afton subbasin, station M11-109. 50-cm shovel for scale with head at top of thin Qia6 overlying Q16, which consists of tan, planar-bedded sand with rip-up clasts of green mud, separated from overlying Q17 by about $60 \mathrm{~cm}$ of gravelly sand with tufa-coated clasts (photo index number 11-376).

Photo 12. Layered oncoid tufa coats on clasts at base of unit Q17, south side of Mojave River, Afton subbasin (photo index number 08-106).

Photo 13. Layered oncoid tufa coats on clasts at base of unit Q17, Dunn wash, Afton subbasin, station M07-19B. Note bumpy stromatolitic texture on surface, typical of oncoid coats in Lake Manix deposits (photo index number 05-112).

Photo 14. Units Q17b (green mud) and Q17a (tan planar-bedded pebbly sand and silt) overlying pinkish unit Qalg. Section M06-81 near Field siding, Afton subbasin. Geologist and dog for scale (sheet 2B; photo index number 06-156). 
Photo 15. Units Q17b (greenish-gray sandy mud) and Q17a (pink and green interbedded sand and pebble gravel) overlying reddish unit Qiea. Weak soil present at top of Q17a. Q17a was deposited in a fan-delta setting and thus locally contains packages of fluvial gravel (Reheis and Miller, 2010). Section is about $10 \mathrm{~m}$ thick. Station M06-160 near Shoreline hill, Afton subbasin (sheet 2C; photo index number 06-522).

Photo 16. Unit Q17a, deposited in a fan-delta setting. Includes fluvial gravel, beach deposits (backset and foreset beds) and deltaic foreset and topset beds. 50-cm shovel for scale. Station M06-135, east side of North Afton beach ridge, Afton subbasin (sheet 2D; photo index number 06-471).

Photo 17. Unit QI6, overlying unit Qia. Fine to medium sand in long sweeping northeast-directed crossbeds; upper part locally contains reworked green muds in lenses. Station M05-54, railroad cut northeast of Dunn in Afton subbasin (sheet 2C; photo index number 05-370).

Photo 18. Unit QI6, same station as Photo 17. Well bedded fine sand, weakly cemented by calcium carbonate. Station M05-54, railroad cut northeast of Dunn in Afton subbasin (sheet 2C; photo index number 06-118).

Photo 19. Unit Q16, showing large green rip-up mud clasts embedded in sand matrix. Clasts were derived from erosion of lake deposits in Cady subbasin during subbasin integration event. Station M11-109, south side of Mojave River in Afton subbasin (photo index number 11-378).

Photo 20. Unit Q16, showing interbedded medium and fine sand and sandy mud; white lamina is 184-ka Manix tephra. Green bed near base of scale consists of reworked rip-up mud clasts. Station M07-159 northeast of Dunn, Afton subbasin (sheet 2C; photo index number 07-566).

Photo 21. Unit Q16, showing rip-up mud clasts and gravel at base of pebbly sand also containing smaller mud rip-ups, and capped by a transgressive gravel marking base of Q17. Station M09-58 south of Mojave River in Cady subbasin (sheet 2A; photo index number 09-181).

Photo 22. Interbedded lacustrine and alluvial-fan beds, south of Mojave River in Cady subbasin. Q17 consists of sandy mud and wellsorted nearshore sand; QI6 consists of horizontally bedded fine to coarse sand with heavy-mineral laminae. Note white concentration of calcium carbonate at base of unit Q17. Numbers on scale are 10-cm intervals. Station M09-66 (sheet 2A; photo index number 09-234).

Photo 23. Sequence of three lacustrine units overlying unit Qalg, northeast side of Manix Wash, Cady subbasin. About $1 \mathrm{~m}$ of muddy nearshore sand of unit Q17 at top is obscured by lag gravel (note daypack for scale). Q15 consists of an upper interval of nearshore sand overlying beach gravel with tufa-coated clasts throughout. Q14 consists of pale-colored, horizontally bedded arkosic sand. Hoodoo of unit Qalg at right capped by cemented sandstone lens. Station M08-110 (sheet 2A; photo index number 08-365).

Photo 24. View to southeast of strath terraces capped by Mojave River gravel (Qyfmr) near the head of Afton Canyon. Straths are inset into various units, including unit Tgg forming skyline and plutonic rocks $(\mathrm{Br})$ in middle ground. Also inset below deposits of Lake Manix overlying units Qiea and QTcg. Mojave River (Qfmr) and railroad bridge in right middle ground (sheet 1; photo index number 06-77).

Photo 25. View to south of strath terraces capped by Mojave River gravel (Qyfmr) south of Buwalda Ridge (foreground). Terraces are cut into unit Qvg. Mojave River channel (unit Qfmr; about $0.5 \mathrm{~km}$ wide) and active dune sand (Qye and Qyea) in middle ground. Photo taken at approximate location of inferred threshold formerly separating Cady and Afton subbasins (photo index 07-205).

Photo 26. View to south of unit Qif, fluvial deposits in middle ground above north rim of Afton Canyon. Foreground is colluvium on plutonic rocks (unit Br); background is unit Tgg. Station JR04CM-87 (Reheis and Redwine, 2008; photo index number 04-163).

Photo 27. View to southeast of unit Qif (center middle ground) and thin inset strath terrace of unit Qyfmr to right, overlying bedrock above north rim of Afton Canyon. Station JR04CM-87 (Reheis and Redwine, 2008; photo index number 06-512).

Photo 28. View to northeast of unit Qof overlying unit Ta; capped by strath gravel of unit Qyfmr. Exposure is about $17 \mathrm{~m}$ high. Qof consists of interbedded sand and gravel with individual beds 10-60 cm thick. Station M07-144 east of Mojave River in Afton subbasin, northeast of Ninemile Well (sheet $2 B$; photo index number $07-300$ ).

Photo 29. Closeup of part of Qof outcrop in photo 28. Thinly bedded sand and pebbly sand (near base). Note steeply north-dipping beds above shovel head (50 cm shovel). Station M07-144 east of Mojave River in Afton subbasin, northeast of Ninemile Well (sheet 2B; photo index number 07-302). 
Photo 30. Closeup of part of unit Qof outcrop showing reddish, weak buried soil overlain by fluvial sand and gravel containing large (about $50 \mathrm{~cm}$ across) rip-up clast of green mud (right of shovel head). Near station M08-45, east of Mojave River, northeast of Ninemile Well (sheet 2B; photo index number 11-39).

Photo 31. Closeup of unit Qof containing rip-up clasts of green mud in a poorly sorted matrix of gravel, sand, and small mud chips. Qof overlies buttress unconformity on unit Qalg, sloping about $25^{\circ}$ up to left from GPS. Unconformity is inferred to have been cut by flood waters during subbasin integration. Station M07-117 on east end of Buwalda Ridge (sheet 2B; photo index number 09-332).

Photo 32. Unit Qof as fluvial terrace cut into unit Qp (brown sandy mud). Geologist for scale. Station M06-68, northwest side of Mojave River, Afton subbasin (photo index number 06-126).

Photo 33. Closeup of outcrop in photo 32, showing lenses of green mud rip-ups in fluvial sand and gravel of unit Qof, overlying brown playa deposits of unit Qp. Station M06-68, northwest side of Mojave River near Dunn, Afton subbasin (photo index number 06-127).

Photo 34. View south of unit Qof overlying brown playa deposits of unit Qp. Qof consists of about $1 \mathrm{~m}$ of fluvial sand and gravel overlying several meters of chaotically bedded blocks (as much as $2 \mathrm{~m}$ across) and clasts of deformed, semi-indurated green lake mud, silt, and sand mixed with blocks of brown playa mud. Station M06-100, northeast side of Mojave River near Dunn, Afton subbasin (sheet 2B; photo index number 07-311).

Photo 35. Closeup of rip-up clast of deformed lake sand and mud (left of shovel head) overlying brown rip-up clast of playa sediment at station M06-100. 50-cm shovel for scale. Northeast side of Mojave River near Dunn, Afton subbasin (sheet 2B; photo index number 06-196).

Photo 36. Bedding in conglomerate Tqg at map boundary in Afton subbasin, south of Mojave River. Dominantly composed of wellrounded, flow-banded rhyolite and quartz-rich granitoids, with lesser amounts of mafic volcanic clasts. Sandy cemented bed about $30 \mathrm{~cm}$ thick. Station M12-4, just south of map boundary (photo index number 12-46).

Photo 37. Lenticular body of freshwater limestone interbedded with unit Tqg in Afton subbasin, south of Mojave River. Geologist and dog for scale. Station M12-3, just south of map boundary (photo index number 12-37).

Photo 38. Orange-stained outcrop of unit Tqg overlain by rhyolite and andesite of unit Tvs. Contact of rhyolite over Tqg continues up slope on far right to near top of ridge. Station M12-8 at map boundary in Afton subbasin, south of Mojave River (photo index number 12-56).

Photo 39. Unit Qia, interbedded poorly sorted alluvial gravel and sand, overlain by units Q17 and Q18. West side of North Afton beach ridge, Afton subbasin (sheet 2C; photo index number 08-17).

Photo 40. View to west of the eastern end of Buwalda Ridge. Sequence of lake units Q18 (tan sand), Q17 (pale green mud), Qia (pinkish sand and gravel), and Qalg (pale-colored sand and minor pebble gravel). Qia is less indurated and more gravelly than Qalg, but has similar arkosic composition with clasts of varied lithology. Station M07-119, north of Mojave River on western end of Afton subbasin (photo index number 07-264).

Photo 41. Unit Qalg on south side of Buwalda Ridge near eastern end. Capped by gravels of unit Qof. Desert tortoise (Gopherus agassizii) in foreground for scale (sheet $2 A$; photo index number 07-259).

Photo 42. View to northwest showing sequence of lacustrine, alluvial, and playa deposits exposed at station M10-86. Manix fault runs between Buwalda Ridge on skyline and dissected deposits in front of it. Unit Q17 overlies thin Q16 over Qia, resting on erosional unconformity. Beneath unconformity is weakly consolidated sand and pebble gravel of unit Qalg, which here rests on a slight angular unconformity cut on unit Qmr. At base of unit Qalg are lenses of ashy sediment, analyzed in the next drainage west at station M10-94 (table 2), thought to be early Pleistocene in age (see map text). Station M10-86 (sheet 1; photo index number 10-198).

Photo 43. View to east showing sequence of lacustrine and alluvial deposits south of Mojave River near Afton Canyon and eastern margin of Afton subbasin. Unit Q17 (green mud) caps right skyline; overlies weakly consolidated alluvial-fan gravel of unit Qia, in turn conformably overlying unit Qvg (light brown, forming steep slopes in middle ground). Qvg rests unconformably on pinkish deposits of unit QTcg in left middle ground (sheet 1; photo index number 05-84).

Photo 44. Closer view of sequence similar to that in photo 40, showing Q17 over Qia (vertical cliff) over Qvg (more gullied, steeply sloping) over pink QTcg with white calcic soil at top (photo index number 06-496).

Photo 45. Unit Qvg conformably overlying unit Qmr at station M09-48, south side of Mojave River in Cady subbasin, near station M08-164 (table 2). Daypack marks bed of 2-Ma Huckleberry Ridge tephra within unit Qmr. The first incursion of volcaniclastic fan gravel of unit Qvg is $1.5 \mathrm{~m}$ higher, and such beds increase upward through another $2.5 \mathrm{~m}$ until they are dominant (photo index number 09-175). 
Photo 46. Two facies of unit QTvg separated by a low-angle fault. Footwall is middle part of QTvg that is finer-grained and dominantly volcaniclastics; hanging wall is older part of part of QTvg that contains up to 20 percent flow-banded rhyolite and siliceous dike rocks (see unit description). Another fault separates QTvg from red-weathering basalt flow (unit Tvs) near skyline. Station M11-50 near map boundary south of Mojave River in Afton subbasin (photo index number 11-98).

Photo 47. Reworked eolian sand interbedded with gravels of unit QTvg. Near station M09-196, close to map boundary south of Mojave River in Afton subbasin (photo index number 09-287).

Photo 48. View to northwest of lower part of QTvg containing component of rhyolite and siliceous dike rocks (likely reworked from Tqg), overlying red-weathering basalt (unit Tvs). Basalt in turn is faulted against middle, dominantly volcaniclastic part of QTvg. Close to map boundary south of Mojave River in Afton subbasin (photo index number 11-107).

Photo 49. View west along south margin of Buwalda Ridge showing unit Tbrg cut by inactive strand of Manix fault in photo center. Channel of Mojave River on left (unit Qfmr). Near former threshold of Cady and Afton subbasins—see photo number 25 (sheet 1; photo index number 07-204).

Photo 50. View northeast near summit of Buwalda Ridge on its eastern end, showing southeast-dipping Tbrg; white streak in upper left is tephra layer (3.4-Ma tuff of Mesquite Springs), samples M07-10a and b (table 2). Afton subbasin (photo index number 07-271).

Photo 51. Closer view of two tephra lenses at station M07-101 (table 2, photo 50); both are about $7 \mathrm{~cm}$ thick at thickest point. Both samples correlated with 3.4-Ma tuff of Mesquite Springs. Afton subbasin (photo index number 07-241).

Photo 52. View to north of north-dipping beds of granitic fanglomerate Tgg. Trucks on highway visible in background. Station M08-98, south of Dunn and Mojave River, Afton subbasin (photo index number 08-344).

Photo 53. Base of unit Tgg on its southern flank near Manix fault. Basal part of unit composed mainly of reworked clasts of pink andesite tuff (unit Tvs), which underlies Tgg. Near station M08-88 (photo index number 08-475).

Photo 54. View to northeast of playa and distal-fan deposits of unit Qp in Afton subbasin. Most gravel in lower part of image is lagged down from a one-clast-thick gravel bed in middle of outcrop. Near station M06-66 northeast of Mojave River near Dunn (photo index number 06-123).

Photo 55. View to east of playa and distal-fan deposits of unit Qmr (Mojave River formation) near western end of Buwalda Ridge in Cady subbasin. In upper left, resistant pale-colored bed marks approximate contact of overlying unit Qalg as herein mapped (sheet 1; photo index number 09-278).

Photo 56. View to southeast of playa deposits of unit Qmr, south of Mojave River near mouth of Manix Wash in Cady subbasin. Scraped white area near shovel in foreground is 2-Ma Huckleberry Ridge tephra, as identified by Nagy and Murray (1991) in their "southern hill section". White streak partway up mud bluffs is another tephra. Station M09-41 (sheet 2A; photo index number 09-159).

Photo 57. Tephra within unit Qmr identified as one of the 2.2-2.1-Ma tuffs of Blind Spring Valley (M07-128, table 2, sheet 2A). 50-cm shovel for scale. About 3-4 m higher, to left of this view, unit Qmr contains Huckleberry Ridge tephra (M10-90, table 2). Basal part of outcrop includes interbedded sand and mudcracked silt and mud layers. Sands display planar cross-beds and climbing ripples indicating southwesterly flow. South side of Mojave River in Cady subbasin (photo index number 07-283).

Photo 58. Closeup of tephra in photo 57 , station M07-128. Basal $\sim 2 \mathrm{~cm}$ of tephra very clean, likely deposited by air-fall on a mudcracked playa surface. Reworked upward and interbedded with silt and very fine sand. South side of Mojave River in Cady subbasin (photo index number 07-281).

Photo 59. Playa and distal-fan deposits of unit Ta, near eastern end of Buwalda Ridge near mouth of Field wash. A few hundred meters to west, similar deposits interfinger with gravels of unit Tbrg. Station M06-103, northwest of Mojave River in Afton subbasin (photo index number 06-206).

Photo 60. Reworked eolian sand and scattered pebble gravel of unit Qiea. Note vertical carbonate root casts in sand beds. 50-cm shovel for scale. Station M05-72, east side of North Afton beach ridge, Afton subbasin (photo index number 05-395).

Photo 61. Interbedded reworked eolian sand and gravel beds of unit Qiea, overlain by greenish unit Q17. Station M06-40, east side of North Afton beach ridge, Afton subbasin (sheet 2D; photo index number 06-81). 


\section{Tables}



Table 1. Radiocarbon ages and site information for samples from Afton and Cady subbasins of Pleistocene Lake Manix.

[Sample letters (for example, A, B, and so forth) indicate multiple samples taken from the same section or station. m, meters; B.P., years before the present; s.d., standard deviation]

\begin{tabular}{|c|c|c|c|c|c|c|c|}
\hline Station & $\begin{array}{c}\text { Lab } \\
\text { number }\end{array}$ & $\begin{array}{c}\text { Altitude } \\
(\mathrm{m})^{3}\end{array}$ & Samples & $\delta^{13} C^{4}$ & $\begin{array}{l}\text { Age }^{5} \\
\text { (B.P.) }\end{array}$ & 1 s.d. & Description \\
\hline M04-23 & WW4771 & 539 & Anodonta valves & n.d. & 21,780 & 70 & $\begin{array}{l}\text { In-situ whole shells in nearshore sand overlying mud and silt beds; capped by weak buried soil; overlain by } \\
\text { dune sand. South of Mojave River }\end{array}$ \\
\hline $\mathrm{M} 04-32 \mathrm{~A} / \mathrm{B}$ & WW4772 & 557.8 & Anodonta fragments & n.d. & 20,810 & 60 & Well bedded dune sand containing shell fragments in individual layers. North of North Afton beach ridge \\
\hline M04-74 & WW5279 & 535 & Anodonta valves & n.d. & 28,170 & 120 & $\begin{array}{l}\text { Measured section in station M09-6 in railroad cut west of Dunn siding. } 4 \text { units within map unit Q18. } \\
\text { Abundant shells in S-dipping foreset sand beds above buried soil; } 2.6 \mathrm{~m} \text { above base of outcrop }\end{array}$ \\
\hline M04-75 & WW5357 & 542 & Anodonta valves & n.d. & 22,470 & 70 & $\begin{array}{l}\text { Two lake units; upper unit contains shells } 1.25 \mathrm{~m} \text { below surface; overlies lower unit capped by debris flow } \\
\text { and mottled red and white buried soil. West end of Buwalda Ridge }\end{array}$ \\
\hline M05-07 & WW5339 & 549 & Anodonta fragment & n.d. & 32,690 & 210 & $\begin{array}{l}\text { Uppermost limit of probable lake sediment, unit Q17?; well sorted sand about } 0.5 \mathrm{~m} \text { below distinct buried } \\
\text { soil. West end of Buwalda Ridge }\end{array}$ \\
\hline M05-19I & WW5340 & 526.0 & Anodonta fragments & n.d. & 34,680 & 260 & $\begin{array}{l}\text { Measured section in upper Dunn wash at pipeline crossing. Upper } 3 \text { lake units within map unit Q18, lowest } \\
\text { 4th unit Q17. Sampled shell in second unit from top, } 80 \mathrm{~cm} \text { below surface }\end{array}$ \\
\hline M05-20A & WW5628 & 527.5 & $\begin{array}{l}\text { Anodonta, } \\
\text { whole shell }\end{array}$ & n.d. & 49,800 & 2,000 & Shells are from just above oncoid tufa-coated clasts at base of unit Q17, upper Dunn wash \\
\hline M05-21 & WW5629 & 535.4 & Anodonta fragments & n.d. & 31,900 & 200 & Shells from $40 \mathrm{~cm}$ below surface in second Q18 unit from top; upper Dunn wash \\
\hline $\mathrm{M} 05-22 \mathrm{H}$ & WW5341 & 539.4 & Anodonta valve & n.d. & 27,000 & 120 & Measured section on east side of North Afton beach ridge; shells sampled at very top in unit Q18 \\
\hline M05-23C & WW5342 & 515 & $\begin{array}{l}\text { Anodonta, } \\
\text { whole shell }\end{array}$ & n.d. & 40,120 & 500 & $\begin{array}{l}\text { Measured section on east side of North Afton beach ridge. Shells from } 1 \mathrm{~m} \text { above oncoid tufa-coated clasts } \\
\text { at base of unit QI7 }\end{array}$ \\
\hline M05-25J & WW5630 & 539 & $\begin{array}{l}\text { Anodonta valves, } \\
\text { weathered }\end{array}$ & n.d. & 45,490 & 1,200 & $\begin{array}{l}\text { Measured section on east side of North Afton beach ridge. Shells from } 2.8 \mathrm{~m} \text { above oncoid tufa-coated } \\
\text { clasts at base of unit Q17 }\end{array}$ \\
\hline M05-26F & WW5631 & 521.7 & $\begin{array}{l}\text { Anodonta, } \\
\text { whole shell }\end{array}$ & n.d. & 40,000 & 600 & $\begin{array}{l}\text { Measured section on west side of North Afton beach ridge. Tufa-coated shells from } 9.2 \mathrm{~m} \text { above oncoid } \\
\text { tufa-coated clasts at base of unit Q17 and } 25 \mathrm{~cm} \text { below Bwk soil formed in unit Qia7 }\end{array}$ \\
\hline M05-26G & WW5632 & 532.2 & Anodonta fragments & n.d. & 29,630 & 190 & $\begin{array}{l}\text { Measured section on west side of North Afton beach ridge. Sands containing shells, fish bones, and snails } \\
\text { within unit Q18, } 9.1 \mathrm{~m} \text { above unit Qia7 }\end{array}$ \\
\hline M05-28B & WW5343 & 532.2 & Anodonta valves & n.d. & 26,030 & 100 & $\begin{array}{l}\text { Shells lie in greenish lagoonal sediment of unit Q|8, just above tufa-coated clasts on weak buried soil west } \\
\text { of pipeline crossing in upper Dunn wash }\end{array}$ \\
\hline M05-62 & WW5633 & 533.8 & $\begin{array}{l}\text { Anodonta, } \\
\text { whole shell }\end{array}$ & n.d. & 28,440 & 160 & $\begin{array}{l}\text { Large, abundant shells in beach sand and gravel of unit Q18 } 1 \mathrm{~m} \text { above unit Qia7, on west side of North } \\
\text { Afton beach ridge }\end{array}$ \\
\hline M05-62A & WW7485 & 533.2 & Anodonta fragments & -3.7 & 30,600 & 240 & Shell fragment in beach gravel $45 \mathrm{~cm}$ above base of unit Q18, on west side of North Afton beach ridge \\
\hline M05-62A-2 & WW7851 & 533.2 & Anodonta fragments & -3.7 & 31,840 & 270 & Re-analysis of sample M05-62A \\
\hline M05-62C & WW7486 & 534.0 & $\begin{array}{l}\text { Anodonta, } \\
\text { whole shell }\end{array}$ & -4.9 & 26,620 & 150 & $\begin{array}{l}\text { Whole shell in beach gravel } 1.4 \mathrm{~m} \text { above base of unit Q18; just below green mud bed; west side of North } \\
\text { Afton beach ridge }\end{array}$ \\
\hline M06-35A & WW5882 & 526.0 & $\begin{array}{l}\text { Anodonta } \\
\text { valves }\end{array}$ & n.d. & 47,430 & 930 & $\begin{array}{l}\text { Abundant shells in horizontally bedded beach sand just above oncoid tufa-coated clasts at base of unit Q17; } \\
\text { east side of North Afton beach ridge }\end{array}$ \\
\hline M06-62D & WW5885 & 538.6 & Anodonta valve & n.d. & 21,310 & 50 & $\begin{array}{l}\text { Shells in-situ } 30 \mathrm{~cm} \text { below surface of beach gravel, } 0.7 \mathrm{~m} \text { thick; overlies Bwk on dune (?)sand; west side } \\
\text { of North Afton beach ridge }\end{array}$ \\
\hline M06-89 & WW5886 & 535.3 & $\begin{array}{l}\text { Anodonta, } \\
\text { whole shell }\end{array}$ & n.d. & 23,130 & 70 & $\begin{array}{l}\text { Measured section M09-6 in railroad cut west of Dunn siding. } 4 \text { units within map unit Q18. Shell is from } \\
\text { uppermost unit, } 0.75 \text { m below surface, above buried soil }\end{array}$ \\
\hline M06-116A & WW6070 & 533.1 & $\begin{array}{l}\text { Anodonta, } \\
\text { whole shell }\end{array}$ & -1.9 & 21,140 & 70 & $\begin{array}{l}\text { Whole shell in beach sand and gravel, } 50 \mathrm{~cm} \text { above beach cobbles within unit Ql8; west side of North } \\
\text { Afton beach ridge }\end{array}$ \\
\hline M06-116B & WW6070 & 533.6 & Anodonta valve & -4.9 & 20,510 & 70 & Whole shell in beach sand, $1 \mathrm{~m}$ above beach cobbles within unit Q18; west side of North Afton beach ridge \\
\hline M07-29 & WW6343 & 522.6 & Anodonta valve & -7.0 & 36,040 & 400 & Measured section M07-62. Shell in younger of two subunits of Q18 near top of railroad cut west of Dunn siding \\
\hline M07-36A & WW6344 & 533.0 & $\begin{array}{l}\text { Anodonta, } \\
\text { whole shell }\end{array}$ & -2.8 & 27,070 & 140 & $\begin{array}{l}\text { Shells in muddy sand and gravel of upper unit Q18; overlie thin debris flow and grade up into lacustrine } \\
\text { sand and beach gravel forming a spit }\end{array}$ \\
\hline M07-131 & WW6346 & 537.2 & $\begin{array}{l}\text { Anodonta, } \\
\text { whole shell }\end{array}$ & -5.3 & 26,860 & 140 & Whole shell in beach sand and gravel of unit Q18, about $60 \mathrm{~cm}$ above unit Qia7; south side of Mojave River \\
\hline
\end{tabular}


Table 1. Radiocarbon ages and site information for samples from Afton and Cady subbasins of Pleistocene Lake Manix.-Continued

[Sample letters (for example, A, B, and so forth) indicate multiple samples taken from the same section or station. m, meters; B.P., years before the present; s.d., standard deviation]

\begin{tabular}{|c|c|c|c|c|c|c|c|}
\hline Station & $\begin{array}{c}\text { Lab } \\
\text { number }\end{array}$ & $\begin{array}{c}\text { Altitude } \\
(\mathrm{m})^{3}\end{array}$ & Samples & $\delta^{13} C^{4}$ & $\begin{array}{l}\text { Age }^{5} \\
\text { (B.P.) }\end{array}$ & 1 s.d. & Description \\
\hline M07-151A2 & WW6345 & 539.5 & Anodonta valves & -3.6 & 21,580 & 70 & $\begin{array}{l}\text { Shells in beach sand and gravel of unit Q18, } 75 \mathrm{~cm} \text { below surface; lie on tufa-coated gravel that caps weak soil } \\
\text { formed on older Q18 sand, in turn unconformably on soil formed on tilted unit Qalg. Upper Manix Wash }\end{array}$ \\
\hline M08-58 & WW6986 & 542.4 & Anodonta fragments & -4.1 & 21,450 & 70 & $\begin{array}{l}\text { Shell fragments in gravel bed } 1 \mathrm{~m} \text { below surface of beach ridge. Beach gravel of unit QI8, } 2.5 \mathrm{~m} \text { thick, } \\
\text { overlies unit Qia7. South of Mojave River }\end{array}$ \\
\hline M08-60C1 & WW6987 & 531.3 & Anodonta valves & -5.0 & 31,510 & 230 & $\begin{array}{l}\text { Measured section on west side of Buwalda Ridge. Five subunits of Q18 separated by tufa-coated clasts or } \\
\text { weak soils overlie truncated soil formed on unit Q17. Shell layer lies } 75 \mathrm{~cm} \text { above base in 4th unit from top }\end{array}$ \\
\hline M08-60C2 & WW6988 & 531.8 & Anodonta valves & -4.2 & 24,400 & 130 & $\begin{array}{l}\text { Measured section on west side of Buwalda Ridge. Five subunits of Q18 separated by tufa-coated clasts or } \\
\text { weak soils. Shell layer lies } 1.35 \mathrm{~m} \text { above base, in third unit from top }\end{array}$ \\
\hline M08-60C3 & WW7616 & 532.0 & Anodonta fragments & -3.8 & 34,970 & 450 & $\begin{array}{l}\text { Measured section on west side of Buwalda Ridge. Five subunits of Q18 separated by tufa-coated clasts or } \\
\text { weak soils. Shell layer } 1.55 \mathrm{~m} \text { above base in } 2 \mathrm{nd} \text { unit from top }\end{array}$ \\
\hline M08-60C3 resample & WW8113 & 532.0 & Anodonta valves & -5.2 & 33,320 & 210 & $\begin{array}{l}\text { Measured section on west side of Buwalda Ridge. Five subunits of Q18 separated by tufa-coated clasts or } \\
\text { weak soils. Shell layer } 1.55 \mathrm{~m} \text { above base in } 2 \mathrm{nd} \text { unit from top. Resampled to check age }\end{array}$ \\
\hline M08-60C4 & WW8114 & 533.0 & Anodonta fragments & -5.2 & 32710 & 190 & $\begin{array}{l}\text { Measured section on west side of Buwalda Ridge. Five subunits of Q18 separated by tufa-coated clasts or } \\
\text { weak soils. Shell layer } 3 \mathrm{~m} \text { above base in uppermost unit }\end{array}$ \\
\hline M08-76A & WW7109 & 524.0 & Anodonta valve & -5.9 & 26,790 & 230 & $\begin{array}{l}\text { Shell layer in greenish sand } 3 \mathrm{~m} \text { above tufa-coated clasts marking base of unit Q18. Overlies green gypsifer- } \\
\text { ous sand and silt of unit Q17. Likely separated from outcrop of M08-76B by fault. South of Mojave River }\end{array}$ \\
\hline M08-76B & WW7110 & 529.0 & Anodonta fragments & -1.8 & 21,980 & 120 & $\begin{array}{l}\text { Shell fragments in tan beach sand, } 3.5 \mathrm{~m} \text { below surface of unit Q18. Poor outcrop. Likely separated by fault } \\
\text { from outcrop of M08-76A. South of Mojave River }\end{array}$ \\
\hline M08-108 & WW7201 & 535.7 & Anodonta valves & -4.7 & 28,230 & 190 & $\begin{array}{l}\text { Shells in beach gravel and sand of unit Q18. To east, unit overlies buried soil formed on gravel capping unit } \\
\text { Q17. Exposed in ditch on N side of railroad service road, upper Manix Wash }\end{array}$ \\
\hline M08-124A & WW7202 & 531.0 & Anodonta valves & -5.3 & 29,090 & 190 & $\begin{array}{l}\text { Shells in ripple-laminated beach sand, } 40 \mathrm{~cm} \text { thick, overlain by } 3 \mathrm{~cm} \text { brown mud. Three subunits of Q18 } \\
\text { present; sample is from 2nd unit below top. West side of Buwalda Ridge }\end{array}$ \\
\hline M08-124 & WW8116 & 532.6 & Anodonta valves & -2.6 & 29,610 & 130 & $\begin{array}{l}\text { Shells in thin bedded fine sand, } 75 \mathrm{~cm} \text { thick, coarsens at base; forms 3rd unit from top, and underlain by } \\
\text { buried soil formed on green mud of unit Q17. West side of Buwalda Ridge }\end{array}$ \\
\hline M08-124C & WW8117 & 532.7 & Anodonta valves & -6.6 & 27430 & 130 & $\begin{array}{l}\text { Shells at base of interbedded sand and pebble gravel, } 3 \mathrm{~m} \text { thick; forms uppermost unit. West side of } \\
\text { Buwalda Ridge }\end{array}$ \\
\hline M08-141 & WW7108 & 531.5 & Anodonta fragments & -2.6 & 34,600 & 570 & $\begin{array}{l}\text { Shell fragments in beach sand and gravel of unit Q18. As much as } 1.2 \mathrm{~m} \text { thick locally; overlies unit QI7, } \\
\text { both units apparently faulted. West side of Buwalda Ridge }\end{array}$ \\
\hline M08-172 & WW7496 & 536.7 & $\begin{array}{l}\text { Anodonta, } \\
\text { whole shell }\end{array}$ & -3.7 & 23,120 & 100 & $\begin{array}{l}\text { Measured section M08-172 in unit Q18 south of Mojave River. Shell layer } 1.0 \mathrm{~m} \text { above base of uppermost unit, } \\
1.7 \mathrm{~m} \text { thick, which rests on a weak buried soil and is capped by } 2.5 \mathrm{~m} \text { poorly sorted pebbly sand (eolian?) }\end{array}$ \\
\hline M08-172A & WW8041 & 533.5 & $\begin{array}{l}\text { Anodonta valves, } \\
\text { weathered }\end{array}$ & -6.7 & 27,920 & 190 & $\begin{array}{l}\text { Measured section M08-172 south of Mojave River. Weathered shells in buried soil formed on green sand } \\
\text { and silt of unit Q18, overlying thickly tufa-coated boulders of unit Qvg. Three subunits present; shells } \\
\text { are in third from top }\end{array}$ \\
\hline M08-172C & WW8042 & 534.9 & $\begin{array}{l}\text { Anodonta, } \\
\text { whole shell }\end{array}$ & -4 & 24,400 & 120 & $\begin{array}{l}\text { Measured section M08-172 south of Mojave River. Shell layer in silt and sand } 1.5 \mathrm{~m} \text { thick, capped by } \\
\text { weak buried soil. Sample lies } 0.9 \mathrm{~m} \text { above base of second unit from top and above sample M08-172A }\end{array}$ \\
\hline M08-172D & WW8043 & 536.7 & Anodonta valves & -3.0 & 23,200 & 100 & $\begin{array}{l}\text { Measured section M08-172 south of Mojave River. Shell layer } 1.0 \mathrm{~m} \text { above base of uppermost unit, } 1.7 \mathrm{~m} \\
\text { thick, which rests on a weak buried soil and is capped by } 2.5 \mathrm{~m} \text { poorly sorted pebbly sand (eolian?). } \\
\text { Resampled to confirm stratigraphic position and age }\end{array}$ \\
\hline M09-5 & WW7492 & 531.3 & Anodonta valve & -5.2 & 35,980 & 450 & $\begin{array}{l}\text { Measured section M09-5 in upper Manix Wash. Shell layer in beach sand of unit QI8, } 20 \mathrm{~cm} \text { above base of } \\
\text { 2nd subunit from top; } 1.4 \mathrm{~m} \text { above base of Q18 }\end{array}$ \\
\hline M09-5 (re-analysis) & WW7852 & 531.3 & Anodonta valve & -5.2 & 35,130 & 400 & $\begin{array}{l}\text { Measured section M09-5 in upper Manix Wash. Shell layer in beach sand of unit QI8, } 20 \mathrm{~cm} \text { above base of } \\
\text { 2nd subunit from top; } 1.4 \mathrm{~m} \text { above base of QI8 }\end{array}$ \\
\hline M09-6A & WW7617 & 533.0 & Anodonta valve & -5.7 & 39,280 & 770 & $\begin{array}{l}\text { Measured section M09-6 at railroad cut west of Dunn siding. } 4 \text { units within map unit Q18. Sample is from } \\
1.6 \mathrm{~m} \text { above base of outcrop }\end{array}$ \\
\hline M09-6B & WW7491 & 534.4 & Anodonta fragments & -3.1 & 27,810 & 170 & $\begin{array}{l}\text { Measured section M09-6 at railroad cut west of Dunn siding. } 4 \text { units within map unit Q18. Sample is from } \\
3.05 \mathrm{~m} \text { above base of outcrop }\end{array}$ \\
\hline
\end{tabular}


Table 1. Radiocarbon ages and site information for samples from Afton and Cady subbasins of Pleistocene Lake Manix.—Continued

[Sample letters (for example, A, B, and so forth) indicate multiple samples taken from the same section or station. m, meters; B.P., years before the present; s.d., standard deviation]

\begin{tabular}{|c|c|c|c|c|c|c|c|}
\hline Station & $\begin{array}{c}\text { Lab } \\
\text { number' }\end{array}$ & $\begin{array}{c}\text { Altitude } \\
(\mathrm{m})^{3}\end{array}$ & Samples & $\delta^{13} C^{4}$ & $\begin{array}{l}\text { Age }^{5} \\
\text { (B.P.) }\end{array}$ & 1 s.d. & Description \\
\hline M10-3A & WW8115 & 522 & Valvata utahensis & -6.2 & 36,410 & 300 & $\begin{array}{l}\text { Fine silty sand in unit Q18 contains abundant snails. Overlies buried soil formed on older subunit. Probably } \\
\text { overlies soil on top of M07-29 unit, or is equivalent to that unit; lies across from measured section M07-62 } \\
\text { at railroad cut west of Dunn siding }\end{array}$ \\
\hline J06-15 & WW7112 & 529.9 & $\begin{array}{l}\text { Anodonta valves, } \\
\text { weathered }\end{array}$ & -2.9 & 33,410 & 490 & $\begin{array}{l}\text { Measured section M09-5 in upper Manix Wash. Weathered shells in greenish fine sand of unit Q18, } 20 \mathrm{~cm} \\
\text { above stone line marking contact with unit QI7, in 4th subunit from top }\end{array}$ \\
\hline J06-16 & WW7113 & 530.6 & $\begin{array}{l}\text { Anodonta valves, } \\
\text { weathered }\end{array}$ & -3.9 & 34,410 & 580 & $\begin{array}{l}\text { Measured section M09-5 in upper Manix Wash. Shell layer lies in ripple-bedded fine sand of unit Q18, } \\
12 \mathrm{~cm} \text { above base of } 2 \text { nd subunit from top; } 1.7 \mathrm{~m} \text { above base of unit Q18 }\end{array}$ \\
\hline J06-17 & WW5850 & 532.5 & Anodonta valves & n.d. & 31,910 & 330 & $\begin{array}{l}\text { Measured section M09-5 in upper Manix Wash. Shell layer lies in medium sand of unit Q18 at top of } \\
\text { outcrop, } 60 \mathrm{~cm} \text { above base of 1st subunit; } 3.05 \mathrm{~m} \text { above base of unit Q18 }\end{array}$ \\
\hline JR04CM-87 & WW8004 & 537.7 & $\begin{array}{l}\text { Limnocythere } \\
\text { bradburyi }\end{array}$ & n.d. & 33,120 & 710 & $\begin{array}{l}\text { Reworked ostracodes in fluvial sand of unit Qif, } 3.5 \mathrm{~m} \text { below surface; overlain by several fan deposits with } \\
\text { buried soils; north rim of Afton Canyon }\end{array}$ \\
\hline JR04D-1 & WW4924 & 541.0 & Anodonta valves & n.d. & 25,420 & 120 & $\begin{array}{l}\text { Shell layer at base of 50-cm-thick beach sand and gravel of unit QI8; overlies buried soil. Occupies fore- } \\
\text { shore of beach ridge in upper Dunn Wash }\end{array}$ \\
\hline JR04D-68 248-255 & WW5384 & 476 & Ostracodes & n.d. & 27,020 & 310 & Bedded sand containing ostracode coquina; slack-water deposits, unit Qysl, $248-255 \mathrm{~cm}$ below surface \\
\hline JR04D-68 331-338 & WW5385 & 476 & Ostracodes & n.d. & 30,540 & 410 & Laminated sand and clay; slack-water deposits, unit Qysl, 331-338 cm below surface \\
\hline JR04D-68B 385-395 & WW4909 & 476 & Ostracodes & n.d. & 28,020 & 160 & $\begin{array}{l}\text { Massive green clay with secondary gypsum and carbonate nodules; slack-water deposits, unit Qysl, } \\
385-395 \mathrm{~cm} \text { below surface. Calgon used to disperse }\end{array}$ \\
\hline JR04D-68A 425-435 & WW4908 & 476 & Ostracodes & n.d. & 30,180 & 210 & $\begin{array}{l}\text { Green silty clay with clay platelets; slack-water deposits, unit Qysl, } 425-435 \mathrm{~cm} \text { below surface. Calgon } \\
\text { used to disperse }\end{array}$ \\
\hline JR04D-68B 385-395 & WW5077 & 476 & Ostracodes & n.d. & 29,280 & 320 & $\begin{array}{l}\text { Massive green clay with secondary gypsum and carbonate nodules; slack-water deposits, unit Qysl, } \\
385-395 \mathrm{~cm} \text { below surface; only distilled water used }\end{array}$ \\
\hline JR04D-68A 425-435 & WW5076 & 476 & Ostracodes & n.d. & 31,500 & 420 & $\begin{array}{l}\text { Green silty clay with clay platelets; slack-water deposits, unit Qysl, } 425-435 \mathrm{~cm} \text { below surface; only } \\
\text { distilled water used }\end{array}$ \\
\hline JR06D-206A & WW5879 & 536.3 & Anodonta valve & n.d. & 21,830 & 60 & $\begin{array}{l}\text { Measured section JR06D-206 in unit Q18, south of Mojave River. } 5 \text { subunits of unit Q18 overlie tufa- } \\
\text { coated clasts on buried soil formed on unit Qia7, overlying green mud of unit Q17. Shell layer is in } \\
\text { beach gravel and sand of uppermost subunit, } 0.5 \mathrm{~m} \text { below surface }\end{array}$ \\
\hline JR06D-206B & WW5880 & 535.3 & $\begin{array}{l}\text { Anodonta, } \\
\text { whole shell }\end{array}$ & n.d. & 20,940 & 60 & $\begin{array}{l}\text { Measured section JR06D-206 in unit Q18, south of Mojave River. } 5 \text { subunits of unit Q18. Shell layer is in } \\
\text { beach sand at base of uppermost subunit, } 1.5 \mathrm{~m} \text { below surface }\end{array}$ \\
\hline JR06D-206C1 & WW5881 & 534.3 & $\begin{array}{l}\text { Anodonta, } \\
\text { whole shell }\end{array}$ & n.d. & 26,620 & 90 & $\begin{array}{l}\text { Measured section JR06D-206 in unit Q18, south of Mojave River. } 5 \text { subunits of unit Q18. Shell layer is in } \\
\text { sand, 4th subunit from top, } 2.5 \text { m below surface }\end{array}$ \\
\hline JR06D-206E & WW7483 & 535.1 & Anodonta valve & -4.9 & 23,140 & 100 & $\begin{array}{l}\text { Measured section JR06D-206 in unit Q18, south of Mojave River. } 5 \text { subunits of unit Q18. Shell layer is at } \\
\text { top of 3rd subunit from top, } 1.6 \mathrm{~m} \text { below surface }\end{array}$ \\
\hline JR06D-206F & WW7484 & 535.3 & $\begin{array}{l}\text { Anodonta, } \\
\text { whole shell }\end{array}$ & -3.0 & 21,780 & 80 & $\begin{array}{l}\text { Measured section JR06D-206 in unit Q18, south of Mojave River. } 5 \text { subunits of unit Q18. Whole shell in } \\
\text { growth position in beach sand at base of uppermost subunit, } 1.5 \mathrm{~m} \text { below surface. Re-collected to check } \\
\text { age of sample JR06D-206B }\end{array}$ \\
\hline
\end{tabular}

${ }^{1}$ Samples were pretreated at the ${ }^{14} \mathrm{C}$ laboratory of the U.S. Geological Survey in Reston, Virginia (WW designation).

${ }^{2}$ All locations given in UTM units, WGS84 coordinates.

${ }^{3}$ Bold font indicates differentially corrected GPS data; altitudes in normal font estimated from topographic map and handheld GPS; Altitudes calculated for individual samples by tape measure up from a datum determinedby GPS or lidar (light detection and ranging). Italics font indicates altitudes from a DEM (Digital elevation Model) created using NASA ATM-III lidar data acquired September, 2004, funded by the U.S. Army Corps of Engineers, WRAP program, R.W. Lichvar \& D.C. Finnegan.

${ }^{4} \delta^{13} \mathrm{C}$ measured on all samples beginning in 2007.

${ }^{5}{ }^{14} \mathrm{C}$ ages were determined at the Center for Accelerator Mass Spectrometry (CAMS), Lawrence Livermore National Laboratory, Livermore, Californa, and at National Science Foundation-Arizona Accelerator Mass Spectrometry facility in Tucson, Arizona. Quoted age is in radiocarbon years (B.P.) using Libby half-life of 5,568 yr. ${ }^{14} \mathrm{C}$ age reflects correction for $\delta^{13} \mathrm{C}$ values if measured. 
Table 2. Locations, correlations, age ranges, and geochemical compositions* in map area.

[Sample letters (for example, A, B, and so forth) indicate multiple samples taken from the same section or station. Ma,million years]

\begin{tabular}{|c|c|c|c|c|c|c|c|c|c|c|c|c|c|c|c|c|}
\hline Station & Easting ${ }^{1}$ & Northing & $\begin{array}{l}\text { Map } \\
\text { unit }\end{array}$ & $\begin{array}{c}\text { Tephra } \\
\text { correlation }\end{array}$ & $\begin{array}{l}\text { Tephra age } \\
\text { (Ma) }\end{array}$ & SiO & Al & $\mathrm{Fe}$ & $\mathrm{MgO}$ & MnO & $\mathrm{CaO}$ & TiO & $\mathrm{Na}$ & K & $\begin{aligned} \text { Total } \\
\text { (Raw) }\end{aligned}$ & Notes \\
\hline M07-101A & 545398 & 3871673 & Tbrg & $\begin{array}{l}\text { Tuffs of } \\
\text { Mesquite } \\
\text { Springs }\end{array}$ & $3.35-3.10$ & 78.23 & 13.42 & 0.75 & 0.04 & 0.08 & 0.46 & 0.06 & 2.76 & 4.18 & 94.29 & $\begin{array}{l}\text { Lower of two tephra beds in highest S-facing part of } \\
\text { east end Buwalda Ridge. Separated by } 2 \mathrm{~m} \text { of sec- } \\
\text { tion. Lenticular and interbedded with fan gravel } \\
\text { up to boulder size }\end{array}$ \\
\hline M07-101B & 545398 & 3871673 & Tbrg & $\begin{array}{l}\text { Tuffs of } \\
\text { Mesquite } \\
\text { Springs }\end{array}$ & $3.35-3.10$ & 78.35 & 13.47 & 0.74 & 0.04 & 0.08 & 0.46 & 0.07 & 2.73 & 4.07 & 93.65 & $\begin{array}{l}\text { Upper of two tephra beds in highest S-facing part of } \\
\text { east end Buwalda Ridge. Separated by } 2 \mathrm{~m} \text { of sec- } \\
\text { tion. Lenticular and interbedded with fan gravel } \\
\text { up to boulder size }\end{array}$ \\
\hline M07-128 & 544564 & 3870904 & Qmr & $\begin{array}{l}\text { Tuffs of } \\
\text { Blind Spring } \\
\text { Valley }\end{array}$ & $\begin{array}{l}2.219 \pm 0.006 \\
-2.135 \pm 0.02\end{array}$ & 77.53 & 13.12 & 0.58 & 0.04 & 0.09 & 0.34 & 0.07 & 4.10 & 4.14 & 94.10 & $\begin{array}{l}\text { Tephra, medium-sand-sized pumice with biotite; } \\
\text { airfall near base; in playa and lacustrine-fluvial } \\
\text { deposits of Mojave River formation (informal) }\end{array}$ \\
\hline M07-145 & 557766 & 3878699 & Tcg & $\begin{array}{l}\text { Ishi Tuff, } \\
\text { correlated } \\
\text { age }\end{array}$ & 2.50 & 78.41 & 13.45 & 0.73 & 0.10 & 0.05 & 0.75 & 0.12 & 2.73 & 3.64 & 93.68 & $\begin{array}{l}\text { Tephra with carbonate cement at top of Cave Mtn. } \\
\text { fanglomerate; reworked, fluvially bedded; over- } \\
\text { lain by fan gravel and fan-delta deposits of Q17 }\end{array}$ \\
\hline M07-159B & 552769 & 3879338 & Q16 & $\begin{array}{l}\text { Manix } \\
\text { Basin } \\
\text { tephra }\end{array}$ & $0.184 \pm 0.04$ & 78.04 & 14.10 & 0.54 & 0.03 & 0.12 & 0.51 & 0.04 & 3.13 & 3.49 & 94.64 & $\begin{array}{l}\text { Between forks of Dunn wash. Unit Q16 contains } \\
\text { tephra about } 2 \mathrm{~m} \text { above Qia fan gravel with fluvial } \\
\text { bedding; tephra is overlain by } \sim 1.2 \mathrm{~m} \text { lake sand, } \\
\text { silt, and reworked chunks of lake mud, capped by } \\
\text { lag gravel }\end{array}$ \\
\hline M08-164 & 542667 & 3868988 & Qmr & $\begin{array}{l}\text { Huckleberry } \\
\text { Ridge } \\
\text { ash bed }\end{array}$ & $2.063 \pm 0.007$ & 76.71 & 12.67 & 1.75 & 0.03 & 0.04 & 0.59 & 0.11 & 3.80 & 4.31 & 94.27 & $\begin{array}{l}\text { 18-cm tephra in Mojave River formation. Sediments } \\
\text { dip } 12^{\circ} \mathrm{SW} \text {. Cut by fault striking } 70^{\circ} \text {, vertical, } \\
\text { down to } \mathrm{S} \text { by } 2.5 \mathrm{~m}\end{array}$ \\
\hline M08-164A & 542667 & 3868988 & Qmr & $\begin{array}{l}\text { Tuffs of } \\
\text { Blind Spring } \\
\text { Valley }\end{array}$ & $\begin{array}{l}2.219 \pm 0.006 \\
-2.135 \pm 0.02\end{array}$ & 76.94 & 13.05 & 0.60 & 0.05 & 0.08 & 0.35 & 0.09 & 4.35 & 4.49 & 93.73 & $\begin{array}{l}\text { Burrowed white lens, } 0-3 \mathrm{~cm} \text { thick, diatomite or } \\
\text { altered tephra, } 3.9 \mathrm{~m} \text { below sample M08-164 on } \\
\text { footwall of fault }\end{array}$ \\
\hline M08-164B & 542667 & 3868988 & Qmr & $\begin{array}{l}\text { Tuffs of } \\
\text { Emigrant Pass, } \\
\text { correlated age }\end{array}$ & $<2.063,>1.96$ & 77.30 & 12.91 & 0.67 & 0.02 & 0.09 & 0.31 & 0.07 & 4.43 & 4.19 & 93.05 & $\begin{array}{l}\text { Lenticular, } 0-3 \mathrm{~cm} \text { thick, } 1.1 \mathrm{~m} \text { above sample } \\
\text { M08-164 on hanging wall of fault }\end{array}$ \\
\hline M10-90 & 544673 & 3871144 & Qmr & $\begin{array}{l}\text { Huckleberry } \\
\text { Ridge } \\
\text { ash bed }\end{array}$ & $2.063 \pm 0.007$ & 76.35 & 12.44 & 1.74 & 0.04 & 0.06 & 0.60 & 0.11 & 3.71 & 4.95 & 93.53 & $\begin{array}{l}\text { 3 m above tephra M07-128 at sharp fold in Qmr. } \\
\text { Thin cemented lens capping escarpment above } \\
\text { playa-lake facies. Above this tephra, deposits are } \\
\text { coarser-grained, redder and more arkosic with } \\
\text { paleosols; mapped as unit Qalg }\end{array}$ \\
\hline M10-94 & 542763 & 3870995 & Qmr & $\begin{array}{l}\text { Similar to } \\
\text { Bishop Tuff, } \\
\text { and youngest } \\
\text { set of tuffs of } \\
\text { Upper Glass } \\
\text { Mountain }\end{array}$ & $\begin{array}{c}0.759 \pm 0.0002 \\
\text { or } \\
1.13 \pm 019-0.87 \\
\quad \pm 0.02\end{array}$ & 77.41 & 12.86 & 0.74 & 0.06 & 0.05 & 0.40 & 0.06 & 4.34 & 4.08 & 92.93 & $\begin{array}{l}\text { Tuffaceous marker bed at contact with reddish upper } \\
\text { Qmr and lower more playa-like Qmr, N side } \\
\text { river. Located near section with paleomagnetic } \\
\text { data of Pluhar and others (1991), which suggests } \\
\text { tephra lies within the Matuyama Reversed Chron } \\
\text { (youngest tephra of Upper Glass Mountain); } \\
\text { however, microprobe data suggest slightly closer } \\
\text { resemblance to Bishop ash }\end{array}$ \\
\hline
\end{tabular}

"Analyses conducted by U.S. Geological Survey Tephrochronology Laboratory in Menlo Park, Calif. Table provided by Elmira Wan. Chemical compositions of volcanic shards determined by electron microprobe analysis. Oxide concentrations are in weight percent oxide recalculated to $100 \%$. Original (raw) oxide totals before recalculations are given to indicate approximate degree of hydration of volcanic glass.

${ }^{1}$ All locations given in UTM units, 11S, WGS 84 coordinates 
Table 3. Site data for Pleistocene Lake Manix surficial map.

[Sample letters (for example, A, B, and so forth) indicate multiple samples taken from the same section or station]

\begin{tabular}{|c|c|c|c|c|c|c|c|c|c|c|}
\hline Station & UTM & Easting' & Northing & Section & ${ }^{14} \mathrm{C}$ sample & Ostracodes & U-series & Tephra & $\begin{array}{c}\text { Soil } \\
\text { description }\end{array}$ & Description \\
\hline M04-23 & $11 \mathrm{~S}$ & 542031 & 3867455 & & $\mathrm{X}$ & & & & & $\begin{array}{l}\text { In-situ whole Anodonta shells in nearshore sands overlying mud and silt beds; } \\
20 \mathrm{~cm} \text { weak Bt; overlain by dune sand }\end{array}$ \\
\hline M04-29B & $11 \mathrm{~S}$ & 551242 & 3880432 & $\mathrm{X}$ & $\mathrm{X}$ & & & & & $\begin{array}{l}\text { Same area as site M03-12 on barrier crest NW of Afton at arroyo. 29B is crest } \\
\text { west of wash; shells dated } 25 \mathrm{ka} \text { in probable buried position }\end{array}$ \\
\hline M04-32 & $11 \mathrm{~S}$ & 558294 & 3879350 & & $\mathrm{X}$ & & & & & $\begin{array}{l}\text { Well-bedded sands containing broken Anodonta shells in individual layers. } \\
\text { A, sampled in-situ fragments from single bed; sample B, float shell pieces }\end{array}$ \\
\hline M04-75 & $11 \mathrm{~S}$ & 542357 & 3871122 & & $\mathrm{X}$ & $\mathrm{X}$ & & & & $\begin{array}{l}\text { Q18 over Q17 and small fault; upper unit contains shells; overlies lower unit } \\
\text { capped by debris flow and paleosol. Surface soil described but not sampled. } \\
\text { 75A, } 1 \mathrm{~m} \text {; 75B, } 1.3 \mathrm{~m} \text {; 75C, } 2.8 \mathrm{~m} \text { (lower lake unit); 75D, 3.4 m; 75E, } 3.8 \mathrm{~m} \\
\text { (upper lake unit) above base of section. 75F, shells } 1.25 \mathrm{~m} \text { below surface }\end{array}$ \\
\hline M04-76 & $11 \mathrm{~S}$ & 542318 & 3871195 & & & $\mathrm{X}$ & & & $\mathrm{X}$ & Soil pit on upper barrier forming loop bar on W end Buwalda Ridge \\
\hline M04-77 & 11 & 542174 & 3871175 & & & & & & $\mathrm{X}$ & Soil pit on lower platform incised into upper barrier, $\mathrm{W}$ end Buwalda Ridge \\
\hline M05-06 & & 542704 & 3871032 & & & & & & $\mathrm{X}$ & $\begin{array}{l}\text { Unconformity on S side Manix fault. Q18 over Q17, thin wedge of younger } \\
\text { above distinctive reddish carbonate soil (described) }\end{array}$ \\
\hline M05-07 & $11 \mathrm{~S}$ & 542650 & 3871188 & & $\mathrm{X}$ & & & & & $\begin{array}{l}\text { Uppermost limit of probable lake sediment, well-sorted sand about } 0.5 \mathrm{~m} \\
\text { below distinct paleosol }\end{array}$ \\
\hline M05-19 & $11 \mathrm{~S}$ & 551614 & 3880174 & $\mathrm{X}$ & $\mathrm{X}$ & $\mathrm{X}$ & $\mathrm{X}$ & & & Base of Q17. Top of oncoid "B" layer where samples M05-19B, C taken \\
\hline M05-20 & $11 \mathrm{~S}$ & 551506 & 3880270 & $\mathrm{X}$ & $\mathrm{X}$ & $\mathrm{X}$ & & & & $\begin{array}{l}\text { Measured section in two lake units (Q|8/Q|7) equivalent to middle two } \\
\text { in section M05-19. A, ostracodes and shells, } 15-20 \mathrm{~cm} \text {; B, 55-60 cm; } \\
\text { C, } 100 \mathrm{~cm} \text { above oncoid B layer. }\end{array}$ \\
\hline M05-21 & $11 \mathrm{~S}$ & 551474 & 3880398 & $\mathrm{X}$ & $\mathrm{X}$ & & & & & $\begin{array}{l}\text { Shells cropping out just below uppermost paleosol in same strat position as } \\
\text { those already dated } \sim 25 \text { ka at location M04-29B?? }\end{array}$ \\
\hline M05-22 & $11 \mathrm{~S}$ & 557663 & 3878175 & $\mathrm{X}$ & $\mathrm{X}$ & $\mathrm{X}$ & & & & $\begin{array}{l}\text { Measured section in upper } 3 \text { lake units on east (back) side of beach ridge; } \\
\text { in-situ shells sampled at very top. A, ostracodes, } 3.5 \mathrm{~m} \text {; B1,2-tufa, } 5.75 \mathrm{~m} \text {; } \\
\text { C, ostracodes, } 6.3 \mathrm{~m} \text {; D-ostracodes, } 7.75 \mathrm{~m} \text {; E1,2-tufa, } 12 \mathrm{~m} \text {; F-ostracodes, } \\
\text { 13.5 m; G-ostracodes, } 17.2 \mathrm{~m} \text {; H-shells, } 22.2 \mathrm{~m} \text { above base of section. } \\
\text { Revisit 4/2/09: } 3 \text { thin beach-gravel units in top } 1.8 \mathrm{~m} \text { of beach ridge, } \\
\text { overlying } 3 \text { thicker units, incl. two sand units separated by soil and a basal } \\
\text { beach gravel over Qia7 }\end{array}$ \\
\hline M05-23 & $11 \mathrm{~S}$ & 557825 & 3877823 & $\mathrm{X}$ & $\mathrm{X}$ & & & & & $\begin{array}{l}\text { Shells in base of Q17a above oncoid tufa layer. C, } 1 \mathrm{~m} \text { above oncoid layer; } \\
\mathrm{D}, 3 \mathrm{~m} \text { above oncoid layer, shells in growth position }\end{array}$ \\
\hline M05-25 & $11 \mathrm{~S}$ & 557859 & 3878180 & $\mathrm{X}$ & $\mathrm{X}$ & $\mathrm{X}$ & $\mathrm{X}$ & & & $\begin{array}{l}\text { Measured section in lowest } 2 \text { of } 4 \text { lake units (Q17b?/Q17a?) on east side of } \\
\text { beach ridge; connects to section M05-22. Following all ostracodes: A1, } \\
8.5 \mathrm{~m}, \mathrm{~A} 2,9 \mathrm{~m} ; \mathrm{B}, 11.2 \mathrm{~m} \text {; C, } 12.2 \mathrm{~m} \text {; D, } 15.9 \mathrm{~m} \text {; E, } 17.3 \mathrm{~m} \text {; F, } 17.9 \mathrm{~m} \text {; } \\
\text { G, } 18.5 \mathrm{~m} \text {; H, 20.8 m; I, tufa, } 21.2 \mathrm{~m} \text {; J, shells } 2.5 \mathrm{~m} \text { below tufa I; K, tufa } \\
\text { clasts in same stratum as J }\end{array}$ \\
\hline M05-26 & $11 \mathrm{~S}$ & 557501 & 3878054 & $\mathrm{X}$ & $\mathrm{X}$ & $\mathrm{X}$ & $\mathrm{X}$ & & & $\begin{array}{l}\text { Measured section in Q18/Q17; } 3 \text { units defined by basal tufa layers. A, thick on- } \\
\text { coid tufa bed at base; B, } 9.4 \mathrm{~m} \text {; and } \mathrm{C}, 18.5 \mathrm{~m} \text { above base. D, seds } \sim 40 \mathrm{~cm} \\
\text { below tufa B and Bwk; E, seds } \sim 35 \mathrm{~cm} \text { below tufa B and Bwk; F, tufa- } \\
\text { coated shells at base of Bwk, } 25 \mathrm{~cm} \text { below tufa B; G, shells and seds, fish } \\
\text { bones and snails, just below tufa C }\end{array}$ \\
\hline M05-28 & $11 \mathrm{~S}$ & 551395 & 3880292 & $\mathrm{X}$ & $\mathrm{X}$ & $\mathrm{X}$ & & & & $\begin{array}{l}\text { Uppermost unit of Q18 above youngest paleosol at pipeline crossing area } \\
\text { (M05-19) on W side Dunn wash where best exposed; here buries tufa 28A }\end{array}$ \\
\hline M05-52E, F & $11 \mathrm{~S}$ & 552100 & 3879626 & $\mathrm{X}$ & & $\mathrm{X}$ & & & & Contact of base of Q18 and underlying beach sand thickening to south. \\
\hline M05-53 & $11 \mathrm{~S}$ & 552967 & 3878677 & $\mathrm{X}$ & & & & & & $\begin{array}{l}\text { Thick sand of Q16 overlies groundwater tufa atop old fan gravel-paleosol- } \\
\text { prelake unit }\end{array}$ \\
\hline
\end{tabular}


Table 3. Site data for Pleistocene Lake Manix surficial map.-Continued

[Sample letters (for example, A, B, and so forth) indicate multiple samples taken from the same section or station]

\begin{tabular}{|c|c|c|c|c|c|c|c|c|c|c|}
\hline Station & UTM & Easting' & Northing & Section & ${ }^{14} \mathrm{C}$ sample & Ostracodes & U-series & Tephra & $\begin{array}{c}\text { Soil } \\
\text { description }\end{array}$ & Description \\
\hline M05-54 & $11 \mathrm{~S}$ & 552283 & 3878810 & $\mathrm{X}$ & & $\mathrm{X}$ & & & & $\begin{array}{l}\text { Same sequence as M05-53 in N-facing railroad cut. Q16. Later sampled sili- } \\
\text { ceous rhizoliths near base of unit for U-series, sample JP-071005-2 }\end{array}$ \\
\hline M05-58 & $11 \mathrm{~S}$ & 549914 & 3876521 & $\mathrm{X}$ & & & & & & $\begin{array}{l}\text { Local top of indurated paleosol-fan unit, here much higher in altitude, overlain } \\
\text { by fluvial sand and gravel dipping north (away from paleo-delta axis?) }\end{array}$ \\
\hline M05-59 & $11 \mathrm{~S}$ & 549877 & 3876657 & $\mathrm{X}$ & & & & & & $\begin{array}{l}\text { Fan gravel on top at M05-58 here overlain by } 2 \mathrm{~m} \text { bedded sand continuing to } \\
\text { rise toward M05-60 }\end{array}$ \\
\hline M05-60 & $11 \mathrm{~S}$ & 549831 & 3876767 & $\mathrm{X}$ & & & & & & $\begin{array}{l}\text { 4-5 m of Ql6 sand overlain by fan gravel with paleosol and then by more thick } \\
\text { sands that grade up to Q17 with rhythmic sand interbeds }\end{array}$ \\
\hline M05-61 & $11 \mathrm{~S}$ & 555389 & 3877936 & $\mathrm{X}$ & & & & & & $\begin{array}{l}\text { Views of Q16 deposits (inset bench) underlying Q17. Basal sands and } \\
\text { underlying gravel over paleosol on older unit with carbonate cement }\end{array}$ \\
\hline M05-62 & $11 \mathrm{~S}$ & 557377 & 3878879 & $\mathrm{X}$ & $\mathrm{X}$ & & & & & $\begin{array}{l}\text { Large in-situ Anodonta shells above and below a 10-cm thick green mud that } \\
\text { is } 60 \mathrm{~cm} \text { above the interlacustral fan gravel, Qia7 }\end{array}$ \\
\hline M05-62B & $11 \mathrm{~S}$ & 555974 & 3876491 & & & & $\mathrm{X}$ & & & $\begin{array}{l}\text { Tufa bench on Qia8; dated } ~ 80 \text { ka by J. Bischoff (USGS) decades ago but } \\
\text { analytical data were lost }\end{array}$ \\
\hline M05-65 & $11 \mathrm{~S}$ & 557172 & 3878279 & $\mathrm{X}$ & & $\mathrm{X}$ & & & & $\begin{array}{l}\text { Below Q17. Fluvial and likely lacustrine deposits of Q16 underlie and overlie } \\
\text { granitic fan gravel of Cave Mtn. origin }\end{array}$ \\
\hline M05-71 & $11 \mathrm{~S}$ & 557731 & 3878737 & $\mathrm{X}$ & & $\mathrm{X}$ & & & & $\begin{array}{l}\text { Delta-like deposits (QI7b over Q17a?) atop QTcg. A, base of delta-like } \\
\text { deposits overlying fan gravel with paleosols }\end{array}$ \\
\hline M06-04 & $11 \mathrm{~S}$ & 552506 & 3878261 & $\mathrm{X}$ & & & & & & Base of Q16 sand atop cemented carbonate layer in sand debris flow \\
\hline M06-05 & $11 \mathrm{~S}$ & 553482 & 3878624 & $\mathrm{X}$ & & & & & & Base of Q16 sand E of railroad cut and Dunn wash \\
\hline M06-06 & $11 \mathrm{~S}$ & 553822 & 3878492 & $\mathrm{X}$ & & & & & & Base of lowest QI6 sand overlying fanglomerate \\
\hline M06-17 & $11 \mathrm{~S}$ & 554275 & 3877569 & $\mathrm{X}$ & & & & & & $\begin{array}{l}\text { Q16. Gray bedded sand, muddy fine sand, and gravel, overlying QTcg; fluvial } \\
\text { crossbedding, including sweeping E-directed beds }\end{array}$ \\
\hline M06-20 & $11 \mathrm{~S}$ & 555917 & 3878065 & & & $\mathrm{X}$ & & & & $\begin{array}{l}\text { Q16. Fluvial sand and gravel overlain by fine sand and green mud, N rim } \\
\text { above slackwater (Qysl) site }\end{array}$ \\
\hline M06-35 & $11 \mathrm{~S}$ & 558394 & 3878183 & & $\mathrm{X}$ & & & & & Basal tufa-coated bed of unit Q17 \\
\hline M06-44 & $11 \mathrm{~S}$ & 558972 & 3877971 & $\mathrm{X}$ & & & & & & $\begin{array}{l}\text { Base of transgressive steep-dipping gravel (Q17b over Q17a) cutting across } \\
\text { dune sand below }\end{array}$ \\
\hline M06-48 & $11 \mathrm{~S}$ & 558467 & 3877105 & $\mathrm{X}$ & & & & & & $\begin{array}{l}\text { Contact between reddish alluvial seds and soils and overlying pale greenish } \\
\text { sand of Q17b overlying Q17a(?). Continued below as section M06-160 }\end{array}$ \\
\hline M06-50 & $11 \mathrm{~S}$ & 558541 & 3876690 & & & & $\mathrm{X}$ & & & $\begin{array}{l}\text { Uppermost point on wavecut bench with tufa-coated stones, base of Q17b } \\
\text { overlying gravelly sand of Q17a (?). Tufa coated wavecut terrace nearest } \\
\text { former outlet, and shoreline angle above }\end{array}$ \\
\hline M06-51 & $11 \mathrm{~S}$ & 558647 & 3876811 & & & $\mathrm{X}$ & & & & Highest outcrop of greenish sands (Q17) interbedded with fan gravel \\
\hline M06-59 & $11 \mathrm{~S}$ & 542851 & 3871160 & & & $\mathrm{X}$ & & & & $\begin{array}{l}\text { Q17. Green sand } 3 \mathrm{~m} \text { above base of lake sand and gravel; overlain by thin } \\
\text { gravel with tufa coats, then } 1.5 \mathrm{~m} \text { beach gravel with Bwk paleosol }\end{array}$ \\
\hline M06-62 & $11 \mathrm{~S}$ & 555809 & 3876066 & & $\mathrm{X}$ & & $\mathrm{X}$ & & & $\begin{array}{l}\text { Shells in-situ } 30 \mathrm{~cm} \text { below surface of Q18 beach gravel, } 0.7 \mathrm{~m} \text { thick grading up } \\
\text { to } 543-\mathrm{m} \text { highstand; overlies Bwk on dune? sand }\end{array}$ \\
\hline M06-62B & $11 \mathrm{~S}$ & 555974 & 3876491 & & & & & & & $\begin{array}{l}\text { Tufa bench on Qia8; dated } 80 \text { ka by J. Bischoff (USGS) decades ago- - but } \\
\text { analyzed data lost. }\end{array}$ \\
\hline M06-70 & $11 \mathrm{~S}$ & 551439 & 3876535 & $\mathrm{X}$ & & $\mathrm{X}$ & & & & $\begin{array}{l}\text { Qof/Qp. Complex section of fluvial gravel, sand, and silt, at least two units, } \\
\text { overlie playa mud and fanglomerates. } 2 / 21 / 11 \text {, I now think some of these } \\
\text { pale sands and silts are groundwater discharge deposits that grade laterally } \\
\text { into the playa muds to the east }\end{array}$ \\
\hline
\end{tabular}


Table 3. Site data for Pleistocene Lake Manix surficial map.-Continued

[Sample letters (for example, A, B, and so forth) indicate multiple samples taken from the same section or station]

\begin{tabular}{|c|c|c|c|c|c|c|c|c|c|c|}
\hline Station & UTM & Easting $^{1}$ & Northing & Section & ${ }^{14} \mathrm{C}$ sample & Ostracodes & U-series & Tephra & $\begin{array}{c}\text { Soil } \\
\text { description }\end{array}$ & Description \\
\hline M06-74 & $11 \mathrm{~S}$ & 550833 & 3876085 & $\mathrm{X}$ & & & & & & $\begin{array}{l}\text { Paleochannel filled with fluvial deposits capped by basaltic coarse gravel } \\
\text { (Qyfmr). Basal unit is debris flow containing large round clasts (Tgg?). } \\
\text { Overlying younger gravelly sand mod-weak indurated with few weak soils, } \\
\text { very sandy; S-directed crossbeds; probably Qia (Qalg) equivalent. }\end{array}$ \\
\hline M06-77 & $11 \mathrm{~S}$ & 550217 & 3876485 & $\mathrm{X}$ & & $\mathrm{X}$ & & & & $\begin{array}{l}\text { Top of fanglomerate overlain by lowest basaltic flood gravel (Qof), grades up } \\
\text { to Q16 sand and fluvial sand, two units apparently; capped by fan gravel }\end{array}$ \\
\hline M06-81 & $11 \mathrm{~S}$ & 547926 & 3875054 & $\mathrm{X}$ & & & & & & $\begin{array}{l}\text { Similar stratigraphy as M06-80 but fluvial deposits here are twice as thick; has } \\
\text { small-scale crossbedding and shows E-directed flow }\end{array}$ \\
\hline M06-91 & $11 \mathrm{~S}$ & 545815 & 3871520 & & & & $\mathrm{X}$ & & & $\begin{array}{l}\text { Contact of Q17 lake seds w/thin green mud above big boulders with tufa coats, } \\
\text { underlain by Qalg unit w/paleosols, S side Buwalda Ridge }\end{array}$ \\
\hline M06-100 & $11 \mathrm{~S}$ & 551658 & 3877284 & $\mathrm{X}$ & & $\mathrm{X}$ & & & & $\begin{array}{l}\text { Unit Qof, "mayhem terrane"; large soft-sediment deformation or highly } \\
\text { deformed, transported lake seds beneath basaltic flood gravel }\end{array}$ \\
\hline M06-104 & $11 \mathrm{~S}$ & 547217 & 3872189 & & & $\mathrm{X}$ & & & & $\begin{array}{l}\text { Fill terrace of unit Qof including bedded sand and silt, about } 8 \mathrm{~m} \text { thick, } \\
\text { overlies playa deposits (unit Ta) }\end{array}$ \\
\hline M06-116 & $11 \mathrm{~S}$ & 557305 & 3879041 & & $\mathrm{X}$ & & & & & $\begin{array}{l}\text { Meek's dating site on sand+gravel Q18 "bumps" below crest of NABR and } \\
\text { possibly inset? Above beach cobbles, A is } 50 \mathrm{~cm} \text { up in interbedded gravel } \\
\text { and sand, B is } 1 \mathrm{~m} \text { up in sands }\end{array}$ \\
\hline M06-135 & $11 \mathrm{~S}$ & 557724 & 3879018 & $\mathrm{X}$ & & & & & & $\begin{array}{l}\text { Point on Qia7 surface. Gilbert-style fan-delta beds developed in Q17a(?) unit, } \\
\text { including tufa on clasts; overlies old fanglomerate (QTcg) downstream; is } \\
\text { overlain by paleosol, Q17b, and Qia7 }\end{array}$ \\
\hline M06-141 & $11 \mathrm{~S}$ & 558406 & 3878483 & $\mathrm{X}$ & & & & & & $\begin{array}{l}\text { E extent of red fanglomerate (QTcg); overlain by two fan-delta units, Q17a } \\
\text { and Q17b, separated by weathering zone and Bwk, in turn by Qia7; fan- } \\
\text { delta units fine and thicken eastward }\end{array}$ \\
\hline M06-142 & $11 \mathrm{~S}$ & 558159 & 3878188 & $\mathrm{X}$ & & & & & & $\begin{array}{l}\text { Near site M06-34; point is probably on Qia7. Two fan-delta units of Q17a and } \\
\text { QI7b overlain by Qia7 and by thin silty sand (QI8?) }\end{array}$ \\
\hline M06-143 & $11 \mathrm{~S}$ & 558406 & 3878162 & & & & $\mathrm{X}$ & & & $\begin{array}{l}\text { Same as site M06-35. Basal green mud of Q17 slopes up to east, pinching out } \\
\text { into a single tufa line with very thick coats, underlain and overlain by fan- } \\
\text { delta deposits and Qia7 }\end{array}$ \\
\hline M06-145 & $11 \mathrm{~S}$ & 558796 & 3877707 & & & & $\mathrm{X}$ & & & Tufa sample at beginning of "tufa ring" (base of Q17) around "Shoreline hill" \\
\hline M06-156 & $11 \mathrm{~S}$ & 559072 & 3877340 & $\mathrm{X}$ & & & & & & $\begin{array}{l}\text { Same site as M04-51A, altitude } 554 \mathrm{~m} \text {. Well-bedded, locally rippled, sands } \\
\text { with heavy-mineral laminations interbedded with angular fan gravel; } \\
\text { paleosol separates two units representing highstands of Q17b (?). }\end{array}$ \\
\hline M06-161 & $11 \mathrm{~S}$ & 555007 & 3878409 & $\mathrm{X}$ & & & & & & $\begin{array}{l}\text { Small outlier of Q17 (a basal sand) preserved under carapace of coarse gravel } \\
\text { in small bump atop main surface }\end{array}$ \\
\hline M06-170 & $11 \mathrm{~S}$ & 554983 & 3879960 & $\mathrm{X}$ & & & & & & $\begin{array}{l}\text { Q17 (adjacent to Afton road). Fines all gone- - here is thick tufa thinly overlain } \\
\text { by Qia7 equivalent with thin tufa }\end{array}$ \\
\hline M06-184 & $11 \mathrm{~S}$ & 552914 & 3879826 & $\mathrm{X}$ & & & & & & $\begin{array}{l}\text { Qia7 at surface overlies Q17, then tan sand and pebble gravel overlying well } \\
\text { bedded and sorted sand and gravel, atop debris flows }\end{array}$ \\
\hline M06-190 & $11 \mathrm{~S}$ & 551847 & 3878317 & $\mathrm{X}$ & & & & & & QI6 sand S side of railroad tracks and $\mathrm{W}$ of previous railroad cut site \\
\hline M07-11 & $11 \mathrm{~S}$ & 551617 & 3879436 & $\mathrm{X}$ & & $\mathrm{X}$ & & & & $\begin{array}{l}\text { Thin fan gravel of Qyao with Bwk, base containing reworked green chunks, } \\
\text { overlying Q18 gravel and sand grading down to green silt and mud of Q18, } \\
\text { about } 3 \mathrm{~m} \text { thick; access road to I-15 }\end{array}$ \\
\hline M07-29 & $11 \mathrm{~S}$ & 548966 & 3876489 & & $\mathrm{X}$ & & & & & $\begin{array}{l}\text { Contact of Qia7 (w/tufa coats on east end of cut) and overlying Q18; Q18 fines } \\
\text { east to muds; contains hiatus and at sample site, base of upper Q18 unit } \\
\text { contains Anodonta; big railroad cut W of Dunn. }\end{array}$ \\
\hline
\end{tabular}


Table 3. Site data for Pleistocene Lake Manix surficial map.-Continued

[Sample letters (for example, A, B, and so forth) indicate multiple samples taken from the same section or station]

\begin{tabular}{|c|c|c|c|c|c|c|c|c|c|c|}
\hline Station & UTM & Easting' & Northing & Section & ${ }^{14} \mathrm{C}$ sample & Ostracodes & U-series & Tephra & $\begin{array}{c}\text { Soil } \\
\text { description }\end{array}$ & Description \\
\hline M07-36A & $11 \mathrm{~S}$ & 547891 & 3876226 & & $\mathrm{X}$ & & & & & $\begin{array}{l}100 \mathrm{~m} \mathrm{NE} \text { of M07-36, whole Anodonta shells in muddy sand and gravel of } \\
\text { Q18 overlying thin debris flow, and grading up into lacustrine sand and silt } \\
\text { then shoreface gravel }\end{array}$ \\
\hline M07-57 & $11 \mathrm{~S}$ & 547403 & 3874467 & $\mathrm{X}$ & & & & & & $\begin{array}{l}\text { Same as (obsolete site) M04-72 (Hole in the Wall). Basal } 15 \mathrm{~m} \text { overlying } \\
\text { debris-flow fanglomerate is fluvial sandy pebble fan deposits-interpreted } \\
\text { fan equivalent of Q17a? Overlying } 4 \mathrm{~m} \text { of x-bedded sand and gravel is } \\
\text { interfingering of Q17b lake with fan }\end{array}$ \\
\hline M07-62 & $11 \mathrm{~S}$ & 549009 & 3876519 & $\mathrm{X}$ & & $\mathrm{X}$ & & & & $\begin{array}{l}\text { Eastern railroad cut (same cut as M07-29), section of basal Q18 unit overlying } \\
\text { Qia7. Two units; younger is dated, but no hiatus (no soil, hardground) at } \\
\text { base, only sharp contact with overlying granule to pebble gravel; transition } \\
\text { more abrupt on N side of cut }\end{array}$ \\
\hline M07-66 & $11 \mathrm{~S}$ & 545742 & 3874373 & $\mathrm{X}$ & & & & & & $\begin{array}{l}\text { Pale reddish sands, massive to flat bedded, thicken downslope (S) across } \\
\text { tracks; intertongue with alluvial gravel that is pebble gravel and coarse } \\
\text { sand-probable fan-lake margin deposits of Q17. Measured section; } \\
\text { point is base of Qia7? Photo is S of tracks in Field wash }\end{array}$ \\
\hline M07-98 & $11 \mathrm{~S}$ & 546276 & 3872179 & & & & $\mathrm{X}$ & & & $\begin{array}{l}\text { Complicated. Site in Field wash is pedogenic carbonate on Tbrg (dipping } \\
25^{\circ} \mathrm{NE} \text { ); terrace displaced about } 1 \mathrm{~m} \text { down to N by fault striking N35E. Soil } \\
\text { overlain by sand and gravel of Qalg, then flat-bedded sand (Q17?) }\end{array}$ \\
\hline M07-101 & $11 \mathrm{~S}$ & 545398 & 3871673 & & & & & $\mathrm{X}$ & & $\begin{array}{l}\text { Two tephra beds in Tbrg in highest S-facing part of east end Buwalda Ridge. } \\
\text { Separated by } 2 \mathrm{~m} \text { of section. Lenticular and interbedded with fan gravel up } \\
\text { to boulder size. A lower than B }\end{array}$ \\
\hline M07-117 & $11 \mathrm{~S}$ & 546716 & 3871703 & $\mathrm{X}$ & & & & & & $\begin{array}{l}\text { Section in Qof and Q17 deposits on NW corner of the triangle terrace near } \\
\text { mouth of Field wash. }\end{array}$ \\
\hline M07-128 & $11 \mathrm{~S}$ & 544564 & 3870904 & $\mathrm{X}$ & & & & $\mathrm{X}$ & & $\begin{array}{l}\text { Tephra, med-sand-sized pumice w/biotite; airfall near base; in playa and } \\
\text { lacustrine-fluvial deposits of Mojave River fm. (informal), (Qmr). At E } \\
\text { end of outcrop, beds are folded up N65E @ 40SE near presumed fault in } \\
\text { Mojave River channel; smaller faults and fractures cut sediments }\end{array}$ \\
\hline M07-131 & $11 \mathrm{~S}$ & 544793 & 3870134 & & $\mathrm{X}$ & & & & & $\begin{array}{l}\text { About } 2 \mathrm{~m} \text { of Q18 is interbedded fine-co sand above a transgressive gravel and } \\
\text { capped by } 50 \mathrm{~cm} \text { regressive gravel; shells are } 60-70 \mathrm{~cm} \text { above gravel }\end{array}$ \\
\hline M07-134 & $11 \mathrm{~S}$ & 546498 & 3869764 & & & & $X$ & & & $\begin{array}{l}\text { Thick tufa coats on boulders at base of Q17. Fan below is rising to W and Q18 } \\
\text { not preserved here. To SW in flanking outcrop is Q17 sand overlain by } \\
\text { reddish eolian sand capped by thin fan gravel with prominent calcic-nodule } \\
\text { soil; the two are separated by a fault, down to S }\end{array}$ \\
\hline M07-144 & $11 \mathrm{~S}$ & 548436 & 3872986 & $\mathrm{X}$ & & & & & & $\begin{array}{l}\text { Top of a fill terrace } 11 \mathrm{~m} \text { thick with beds indicating high-energy flow regime. } \\
\text { Probably similar at base to site M06-141-142 deposits but has been offset } \\
\text { relatively down here }\end{array}$ \\
\hline M07-145 & $11 \mathrm{~S}$ & 557766 & 3878699 & & & & & $\mathrm{X}$ & & $\begin{array}{l}\text { Tephra with carbonate cement in groundwater-affected zone at top of QTcg; } \\
\text { reworked, fluvial bedded; overlain by fan gravel and fan-delta deposits of }\end{array}$ \\
\hline
\end{tabular}

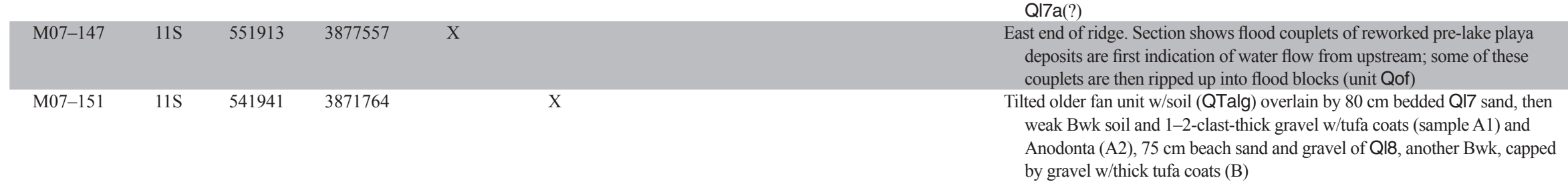


Table 3. Site data for Pleistocene Lake Manix surficial map.-Continued

[Sample letters (for example, A, B, and so forth) indicate multiple samples taken from the same section or station]

\begin{tabular}{|c|c|c|c|c|c|c|c|c|c|c|}
\hline Station & UTM & Easting ${ }^{1}$ & Northing & Section & ${ }^{14} \mathrm{C}$ sample & Ostracodes & U-series & Tephra & $\begin{array}{c}\text { Soil } \\
\text { description }\end{array}$ & Description \\
\hline M07-159 & $11 \mathrm{~S}$ & 552767 & 3879338 & $\mathrm{X}$ & & & & $X$ & & $\begin{array}{l}\text { Between forks of Dunn wash. Section of Ql6 sand contains tephra about } 2 \mathrm{~m} \\
\text { above Qia fan gravel with fluvial bedding; overlain by } \sim 1.2 \mathrm{~m} \text { lake sand, } \\
\text { silt, and reworked Manix mud, capped by lag gravel }\end{array}$ \\
\hline M08-44 & $11 \mathrm{~S}$ & 548837 & 3873861 & $\mathrm{X}$ & & & & & & $\begin{array}{l}\text { Northern limit of Qof outcrop along river channel. Well bedded, x-bedded co, } \\
\text { vco sand and granules, lithic, lots of volc. grains, at least } 4.5 \mathrm{~m} \text { thick; over- } \\
\text { lies calcic soil on debris-flow deposits, capped by } 2 \mathrm{~m} \text { gravel (Qyfmr) }\end{array}$ \\
\hline M08-45 & $11 \mathrm{~S}$ & 548743 & 3873771 & $\mathrm{X}$ & & & & & & $\begin{array}{l}4 \mathrm{~m} \text { playa and distal-fan (brown sandy massive mud, sand lenses, floating } \\
\text { boulders; unit Ta) overlain by } 2 \text { fluvial units (Qof) } 4 \mathrm{~m} \text { and } 8 \mathrm{~m} \text { thick, } \\
\text { separated by debris flow with paleosol; interbedded sand and gravel } \\
\text { w/E-directed crossbeds; top } 2 \mathrm{~m} \text { unit Qyfmr? }\end{array}$ \\
\hline M08-55 & $11 \mathrm{~S}$ & 544683 & 3871119 & $\mathrm{X}$ & & & & & & $\begin{array}{l}\text { S side river, northern point. Qmr on W edge of bluff folded up. Gypsic muds } \\
\text { grade up into Qalg, then that becomes increasingly interbedded upward } \\
\text { with mafic Cady Mtn. clasts (Qvg); all truncated by multiple straths. Qalg } \\
\text { here appears to be arkosic facies of upper Mojave River fm. }\end{array}$ \\
\hline M08-58 & $11 \mathrm{~S}$ & 545652 & 3869849 & & $\mathrm{X}$ & & & & & $\begin{array}{l}\text { Small beach ridge bump (QI8) S of river surmounts high surface, about } 2.5 \mathrm{~m} \\
\text { thick; has reworked shell frags, sampled at base of gravel bed } \sim 1 \mathrm{~m} \text { below } \\
\text { barrier surface }\end{array}$ \\
\hline M08-60C & $11 \mathrm{~S}$ & 541287 & 3871190 & $\mathrm{X}$ & $\mathrm{X}$ & & & & & $\begin{array}{l}\text { Shell site in "member D", E of Manix Wash. } 6 \text { subunits of Q18. Shell layer \#1 } \\
75 \mathrm{~cm} \text { above base in unit 2. Redescribed 4/4/09 and 4/19/10. Resampled } \\
\text { shell \#3, and new sample \#4 in uppermost new unit 1a }\end{array}$ \\
\hline M08-64 & $11 \mathrm{~S}$ & 555977 & 3876486 & & & & X & & & $\begin{array}{l}\text { Base of Q18 on Qia7. Abundant small thick tufa coats; most (all?) not attached } \\
\text { to clasts. Some rinds look like they have silica layers }\end{array}$ \\
\hline M08-70 & & 543581 & 3872470 & & & & & & $\mathrm{X}$ & $\begin{array}{l}\text { Fine-pebble surface of Alvord-derived clasts, mod. sorted, well to mod. } \\
\text { rounded, fairly well bedded; soil pit }\end{array}$ \\
\hline M08-76 & $11 \mathrm{~S}$ & 550538 & 3874023 & $\mathrm{X}$ & $\mathrm{X}$ & & & & & $\begin{array}{l}\text { Base of Q17, overlain by Q18? Poor outcrop; tufa coated clasts at base overlain } \\
\text { by greenish-tan sand; gravel bench } 6-7 \mathrm{~m} \text { higher divides units? Sample } \\
\text { originally } 1 / 2 \text { shell, } 3 \mathrm{~m} \text { above base of Q18 }\end{array}$ \\
\hline M08-100 & & 544170 & 3872562 & & & & & & $X$ & $\begin{array}{l}\text { Fine-pebble surface of Alvord-derived clasts, mod. sorted, well to mod. } \\
\text { rounded, fairly well bedded; soil pit }\end{array}$ \\
\hline M08-108 & $11 \mathrm{~S}$ & 540315 & 3872581 & & $\mathrm{X}$ & & & & & $\begin{array}{l}\text { Ditch on N side of RR access road. } 2 \mathrm{~m} \text { of interbedded sand and gravel of } \\
\text { Q18, not beachy-looking but has shells in two layers; collected basal layer. } \\
20 \mathrm{~m} \text { to east is a paleosol on Qia7 } 50 \mathrm{~cm} \text { below the surface, not present } \\
\text { where shells occur. Later notes indicate samples are in wedge of gravel that } \\
\text { thickens abruptly from paleosol site }\end{array}$ \\
\hline M08-110 & $11 \mathrm{~S}$ & 540330 & 3871695 & $\mathrm{X}$ & & & & & & $\begin{array}{l}25 \mathrm{~m} \text { S of powerline road E side Manix Wash. } 1.0 \mathrm{~m} \text { Q17 sand, tufa at base; } 2.7 \\
\mathrm{~m} \text { "upper B" (Q15?), bedded sand over bedded gravel w/tufa coats; } 0.75 \mathrm{~m} \\
\text { "lower C" (Ql4?), pale bedded arkosic sand, tufa at base; } 2.5 \mathrm{~m} \text { "lower B"?, } \\
\text { oxidized fan deposits, possible paleosol } 1 \mathrm{~m} \text { above outcrop base }\end{array}$ \\
\hline M08-112 & $11 \mathrm{~S}$ & 540611 & 3871782 & $\mathrm{X}$ & & & & & & $\begin{array}{l}\text { Highest outcrop of Q15 beach sand, with paleosol capped by line of tufa- } \\
\text { coated clasts, overlain by fining-up sand, silt and mud of Q17. Comprises } \\
17 \mathrm{~cm} \text { poorly sorted pebbly vco sand with weak soil below transgressive } \\
\text { base of Q17, underlain by } 58 \mathrm{~cm} \text { mod sorted well bedded fi-med sand and } \\
\text { med-vco sand with some pebble beds; heavy-mineral laminations in places. } \\
\text { Colocated with site M09-5. }\end{array}$ \\
\hline
\end{tabular}


Table 3. Site data for Pleistocene Lake Manix surficial map.-Continued

[Sample letters (for example, A, B, and so forth) indicate multiple samples taken from the same section or station]

\begin{tabular}{|c|c|c|c|c|c|c|c|c|c|c|}
\hline Station & UTM & Easting' & Northing & Section & ${ }^{14} \mathrm{C}$ sample & Ostracodes & U-series & Tephra & $\begin{array}{c}\text { Soil } \\
\text { description }\end{array}$ & Description \\
\hline M08-113 & $11 \mathrm{~S}$ & 540614 & 3871866 & $\mathrm{X}$ & & & & & & $\begin{array}{l}\text { "Upper C", actually basal Q18 in age, has Anodonta growth beds. Contact in } \\
\text { notes is actually within "unit D" or Q18, probably Q|8a-Q|8b. } 2 \text { samples } \\
\text { from below contact, } 2 \text { from above }\end{array}$ \\
\hline M08-124 & $11 \mathrm{~S}$ & 540800 & 3871758 & $\mathrm{X}$ & $\mathrm{X}$ & & & & & $\begin{array}{l}\text { Three units of Q18. New sample 124B is } 13 \mathrm{~cm} \text { below unit } 2-3 \text { contact, over- } \\
\text { lain by } 3 \mathrm{~cm} \text { thick brown mud; underlying fi-med sand is ripple-bedded. } \\
\text { Probably same as prev. dated stratum; to north same layer contains shells } \\
\text { and snails as described before, } 50 \mathrm{~cm} \text { below unit contact }\end{array}$ \\
\hline M08-130 & $11 \mathrm{~S}$ & 540973 & 3871581 & $\mathrm{X}$ & & & & & & $\begin{array}{l}\text { Point is base of Q17 capping outcrop; overlies } 270 \mathrm{~cm} \text { Q15, lake-marginal } \\
\text { fluvial deposits, tufa coats at top, over } 130 \mathrm{~cm} \text { x-bedded fluvial sand to } \\
\text { cobble gravel; overlies } 10-15 \mathrm{~cm} \text { Bwk imposed on greenish-brown mud of } \\
\text { Q14, blocky to thinly bedded. Reverse fault strikes E-W @ } 75 \mathrm{~S} \text { near base, } \\
\text { apparently up to S, steepens upward; offsets buried soil by } \sim 60 \mathrm{~cm} \text {, sand } \\
\text { bed } 1 \mathrm{~m} \text { higher by only } \sim 20 \mathrm{~cm} \text {; Q17 at top stops at fault }\end{array}$ \\
\hline M08-141 & $11 \mathrm{~S}$ & 541141 & 3871845 & & $\mathrm{X}$ & & & & & $\begin{array}{l}\text { Between sites M08-140 and -131. S side wash has } ~ 2.5 \mathrm{~m} \text { green mud and } \\
\text { sand of Q17. N side of wash, Q17 only } 25 \mathrm{~cm} \text { thick on W end, overlain by } \\
\text { Q18 beach gravel w/Anodonta, same as intermediate unit at } 131 \text {; but at } \\
\text { E end, Q17 is cut out and beach gravel dropped down } \sim 1.2 \mathrm{~m} \text {; either fault } \\
\text { or cut and fill }\end{array}$ \\
\hline M08-161 & $11 \mathrm{~S}$ & 543402 & 3869953 & $\mathrm{X}$ & & & & & & $\begin{array}{l}\text { Highest butte } \mathrm{S} \text { of river. Mostly Cady-type volc. gravels, but likely } \mathrm{Qmr} \\
\text { in bottom } 1 / 3 \text { (poor outcrop of pale carb-cemented seds). Capped by } 3 \\
\text { lake units: tufa-cemented cobbles overlain by } 1.5 \mathrm{~m} \text { pebble gravel (basalt } \\
\text { cinders); overlain by tufa-cemented cob-bld bed and pebbly cinders grading } \\
\text { up to green silt/sand and coarse beach sand, } 1.7 \mathrm{~m} \text {; overlain by gravel with } \\
\text { thin tufa and } 50 \mathrm{~cm} \text { well-rdd pebble gravel at top; possible fault in gully on } \\
\mathrm{W} \text { face near } \mathrm{N} \text { end }\end{array}$ \\
\hline M08-163 & $11 \mathrm{~S}$ & 542683 & 3868948 & $\mathrm{X}$ & & & & & & $\begin{array}{l}\text { Qmr is interbedded pale pinkish poorly sorted silt and sand capped by strong } \\
\text { groundwater calcrete, overlain by } 3 \text { lake units: } 2 \mathrm{~m} \text { gravel grading to sand, } \\
\text { tufa coats at base; tufa-coated gravel overlain by } 2 \mathrm{~m} \text { sand and a } 5 \text {-cm } \\
\text { green mud, indurated and oxidezed near top; overlain by } 1 \mathrm{~m} \text { pebble-cobble } \\
\text { gravel with thin tufa coats at base, and again at top }\end{array}$ \\
\hline M08-164 & $11 \mathrm{~S}$ & 542667 & 3868988 & & & & & $\mathrm{X}$ & & $\begin{array}{l}\text { 18-cm tephra (Huckleberry Ridge ash) in Qmr } 50 \mathrm{~m} \mathrm{~N} \text { of M08-163. Seds dip } \\
12^{\circ} \mathrm{SW} \text {. Cut by fault striking } 70^{\circ} \text {, vertical, down to } \mathrm{S} \text { by } 2.5 \mathrm{~m} \text {. Another } \\
\text { possible tephra on upthrown side just above wash, not sampled Revisit } \\
2 / 24 / 11 \text { to collect other tephra: burrowed white zone, diatomite or altered } \\
\text { tephra, sample } 164 \mathrm{~A}, 3.9 \mathrm{~m} \text { below HR ash on NW (upthrown) side of fault } \\
\text { where HR ash caps outcrop. } 164 \mathrm{~B}, 1.1 \mathrm{~m} \text { above HR ash on SE (hanging } \\
\text { wall) side of fault }\end{array}$ \\
\hline M08-165 & $11 \mathrm{~S}$ & 544289 & 3868293 & $\mathrm{X}$ & & & & & & $\begin{array}{l}\text { NE flank of basalt hill, ca. } 2 \text { lake units, mostly small-pebble beach gravel and } \\
\text { sand. Base to top: carb-indurated cob-bld bed overlain by } 1.8 \mathrm{~m} \text { x-bedded } \\
\text { partly back-dipping indurated beach gravel; tufa-coated gravel bed at base } \\
\text { of } 1.4 \mathrm{~m} \text { variably bedded sorted material, partly lacustrine or reworked } \\
\text { into fan gravel; tufa-stone line and } 0.75 \mathrm{~m} \text { well sorted fine-pebble gravel; } \\
0.5-0.7 \mathrm{~m} \text { sorted pebble gravel }\end{array}$ \\
\hline
\end{tabular}


Table 3. Site data for Pleistocene Lake Manix surficial map.—Continued

[Sample letters (for example, A, B, and so forth) indicate multiple samples taken from the same section or station]

\begin{tabular}{|c|c|c|c|c|c|c|c|c|c|c|}
\hline Station & UTM & Easting' & Northing & Section & ${ }^{14} \mathrm{C}$ sample & Ostracodes & U-series & Tephra & $\begin{array}{c}\text { Soil } \\
\text { description }\end{array}$ & Description \\
\hline M08-172 & $11 \mathrm{~S}$ & 547942 & 3870478 & $\mathrm{X}$ & $\mathrm{X}$ & & & & & $\begin{array}{l}\text { Tufa coated clasts (GPS point) overlain by } \sim 1.3 \mathrm{~m} \text { green sand and mud of } \\
\text { QI7? (shell A at top in wxd zone), boulder tufa line } 0.5 \mathrm{~m} \text { thick (tufa } \\
\text { sample B), then } 0.9 \mathrm{~m} \text { silty and med-co sand of Q18 to shell layer C, } \\
\text { overlain by } 0.6 \mathrm{~m} \text { similar seds. fining up to blocky greenish muddy sand } \\
\text { overlain by } 0.2 \mathrm{~m} \text { med sand with weak oxidation (soil?) and possible weak } \\
\text { tufa coats, then } 1.0 \mathrm{~m} \text { of pale greenish sand with abundant whole Anodonta } \\
\text { (original sample plus new shell D), overlain by } 0.7 \mathrm{~m} \text { same sand, then tan } \\
\text { poorly sorted pebbly massive sand } 2.5 \mathrm{~m} \text { thick-eolian? }\end{array}$ \\
\hline M09-5 & $11 \mathrm{~S}$ & 540611 & 3871782 & $\mathrm{X}$ & $\mathrm{X}$ & & & & & $\begin{array}{l}\text { Measured section at Oviatt's cone-shaped hill, samples J06-15-17, starting at } \\
\text { base of Q17. Overlies strata of M08-112. } 4 \text { units in Q18. J06-15 at base of } \\
\text { unit 4; J06-16 near top of unit 3; new sample M09-5 } 20 \mathrm{~cm} \text { above base of } \\
\text { unit 2; J06-17 at top of unit } 1 \text { and of hill. Re-analyzed } 05 / 11 / 10\end{array}$ \\
\hline M09-6 & $11 \mathrm{~S}$ & 547480 & 3875665 & $\mathrm{X}$ & $\mathrm{X}$ & & & & & $\begin{array}{l}\text { Measured section of Q18 at } \mathrm{W} \text { railroad cut, site of samples M04-74, M06-89. } \\
\text { In unit 5, } 1.6 \mathrm{~m} \text { above base of section. }\end{array}$ \\
\hline M09-25 & $11 \mathrm{~S}$ & 542193 & 3867143 & & & & & & X & $\begin{array}{l}\text { High beach ridge } \mathrm{S} \text { of Manix Wash. Identical to ridge at M04-23, but coarser- } \\
\text { clast beach ridge that lies to } \mathrm{S} \text { and several m higher-Q17 beach ridge! } \\
\text { Qia7 fan grades to this ridge }\end{array}$ \\
\hline M09-28 & $11 \mathrm{~S}$ & 541811 & 3868823 & $\mathrm{X}$ & & & & & & $\begin{array}{l}4 \text { lake units on QTcg, GPS at section top? QI7b? green beach sand capped by } \\
\text { Qyfmr gravel over fluvial/Bwk/debris flow over QI7a? green beach sand } \\
\text { over Bwk/debris flow over E-dipping Q15? beach gravel over hiatus on } \\
\text { W-dipping QI4? gravelly beach sand }\end{array}$ \\
\hline M09-29 & $11 \mathrm{~S}$ & 542032 & 3868809 & $\mathrm{X}$ & & & & & & $\begin{array}{l}\text { Base of Q14? Fining-up then coarsening-up sequence } ~ 3.5 \mathrm{~m} \text { thick, capped by } \\
\text { fan gravel with tufa coats (Qia4?) }\end{array}$ \\
\hline M09-58 & $11 \mathrm{~S}$ & 542194 & 3868261 & $\mathrm{X}$ & & & & & & $\begin{array}{l}\text { Downslope to N is scarp cut into Qia7/Q17. Slope below is lag gravel, or } \\
\text { inter-Q17 fan, which overlies at least } 2 \text { units, lake sand underlain by thin } \\
\text { fan gravel atop blocky green mud, over "normal" fan gravel with tufa coats } \\
\text { (GPS point). Q17a over Q16? With earthquake effects or lake draining } \\
\text { during Q16 that remobilized lake-bottom muds? }\end{array}$ \\
\hline M09-66 & $11 \mathrm{~S}$ & 542592 & 3868644 & $\mathrm{X}$ & & & & & & $\begin{array}{l}\text { Qia7/QI7 sandy mud and beach sand, } 2 \text { fining-up packages, atop carbonate } \\
\text { line over blocky green sandy mud with Mn stains - back-barrier playa? on } \\
\text { single line of pebbles overlying poorly sorted gravel, atop bedded beach } \\
\text { sand with heavy-mineral laminations (QI6 - highest yet found) }\end{array}$ \\
\hline M09-76 & $11 \mathrm{~S}$ & 544144 & 3869177 & $\mathrm{X}$ & & & & & & $\begin{array}{l}\text { Q17/Q16/Qvg. Q16 in upper part is coarse, like fan-lake interface, and overlain } \\
\text { by fan gravel, inversely graded with large cobbles in a sandy matrix that } \\
\text { includes chunks of green mud - the flood unit }\end{array}$ \\
\hline M09-83 & $11 \mathrm{~S}$ & 541855 & 3868584 & $\mathrm{X}$ & & & & & & $\begin{array}{l}\text { Contact of thin cap of Q18, very arkosic vco sand, capping Q17 (green silty } \\
\text { sand)/ } 6 \mathrm{~m} \text { vco sand and gravel, with } 2 \text { very weak Bwk or hiatus (Q16, } \\
\text { Q15)/thin fan gravel with Bwk and tufa coats/green beach sand (Q14)/Qvg. } \\
\text { So, here lake sequence is largely all beach facies. }\end{array}$ \\
\hline M09-127 & $11 \mathrm{~S}$ & 546709 & 3871652 & $\mathrm{X}$ & & & & & & $\begin{array}{l}\text { "Mayhem" deposits with lumps and clasts of green mud trace beneath basaltic } \\
\text { strath of Qof unit, here }>3 \mathrm{~m} \text { thick and at base with very steep fluvial sand } \\
\text { beds resting on Qalg; } 2 \text { cobble beds mark base. Qof is overlain by Q17 at } \\
\text { nerby site M07-117, but here buried by fan originating from higher Qalg }\end{array}$ \\
\hline M10-3A & $11 \mathrm{~S}$ & 548886 & 3876488 & & $\mathrm{X}$ & & & & & Q18 unit probably overlies soil on top of M07-29 unit. Abundant little snails \\
\hline
\end{tabular}


Table 3. Site data for Pleistocene Lake Manix surficial map.-Continued

[Sample letters (for example, A, B, and so forth) indicate multiple samples taken from the same section or station]

\begin{tabular}{|c|c|c|c|c|c|c|c|c|c|c|}
\hline Station & UTM & Easting $^{1}$ & Northing & Section & ${ }^{14} \mathrm{C}$ sample & Ostracodes & U-series & Tephra & $\begin{array}{c}\text { Soil } \\
\text { description }\end{array}$ & Description \\
\hline M10-59 & $11 \mathrm{~S}$ & 542849 & 3871108 & $\mathrm{X}$ & & & & & & $\begin{array}{l}\text { Contact of base of } 3 \text { lake units over } 3 \mathrm{~m} \text { coarse Buwalda-Ridge-derived cobble } \\
\text { fanglomerate with } 2 \text { buried soils, overlying Qalg (upper Qmr). Lower } \\
\sim 50 \mathrm{~cm} \text { thick, granule beach sand, weak soil at top capped by clast line } \\
\text { (Q16?); middle, presumed Q17, } 6 \mathrm{~m} \text { thick, has } 2 \text { sequences coarse-fining- } \\
\text { up, prominent } 25^{\circ} \text { E-dipping beds suggesting spit or beach backsets, capped } \\
\text { by mottled red-white soil; upper, Q18 sand and gravel }\end{array}$ \\
\hline M10-90 & $11 \mathrm{~S}$ & 544673 & 3871144 & & & & & $\mathrm{X}$ & & $\begin{array}{l}\text { Near tephra M07-128 at sharp fold in Qmr. Thin lens, very cemented, holding } \\
\text { up top of escarpment above playa-lake facies about } 4 \mathrm{~m} \text { above M07-128. } \\
\text { Above this ash, little or no gypsum on surface, deposits are redder and more } \\
\text { arkosic with paleosols like Qalg unit to east, about } 10 \mathrm{~m} \text { thick }\end{array}$ \\
\hline M10-94 & $11 \mathrm{~S}$ & 542763 & 3870995 & & & & & $\mathrm{X}$ & & $\begin{array}{l}\text { Tuffaceous marker bed at contact with reddish upper Qmr and lower more } \\
\text { playa-like Qmr, N side Mojave River }\end{array}$ \\
\hline M11-107 & $11 \mathrm{~S}$ & 553216 & 3876598 & $\mathrm{X}$ & & & & & & $\begin{array}{l}\text { Near base of Meek's (1990) “Cady fan" section. Q17 over Q16 (base not } \\
\text { exposed), including rip-up clasts of green mud. Erosional contact between, } \\
\text { overlain by poorly sorted massive to x-bedded sand and gravel, then fining- } \\
\text { up Q17 sediments }\end{array}$ \\
\hline M12-27 & $11 \mathrm{~S}$ & 542436 & 3871072 & & & & & $\mathrm{X}$ & & $\begin{array}{l}\text { 2-cm lenticular pod of white vitric ash, indurated, in sandy to pebbly arkose of } \\
\text { Qmr. Possibly "upper white ash" of Nagy and Murray (1991) as it appears } \\
\sim 8 \text { m above carbonate-impregnated resistant ledge of silt, but crops out } \\
\text { where beds fold sharply up approaching fault so could be lower in section? }\end{array}$ \\
\hline M12-29 & $11 \mathrm{~S}$ & 542711 & 3870939 & & & & & $\mathrm{X}$ & & $\begin{array}{l}\text { Middle white ash of Nagy and Murray (1991). Lies stratigraphically } 4-5 \mathrm{~m} \\
\text { above site M10-96A that is boundary between mud-playa Qmr and bedded } \\
\text { sandier Qmr, or = G1-C1 boundary of Nagy and Murray }\end{array}$ \\
\hline DI-1 & $11 \mathrm{~S}$ & 550929 & 3877205 & $\mathrm{X}$ & & $\mathrm{X}$ & & & & $\begin{array}{l}\text { Q17. Basal } 2 \text { meters of composite section on SE tip Dunn "island" (large } \\
\text { outcrop of Q17, 1.6 km SW of Dunn }\end{array}$ \\
\hline DI-2 & $11 \mathrm{~S}$ & 550893 & 3877186 & $\mathrm{X}$ & & $\mathrm{X}$ & & & & $\begin{array}{l}\text { Q17. Meters 2-7 of composite section on SE tip Dunn “island," (large outcrop } \\
\text { of Q17, 1.5 km SW of Dunn }\end{array}$ \\
\hline DI-3 & $11 \mathrm{~S}$ & 550756 & 3877214 & $\mathrm{X}$ & & $\mathrm{X}$ & & & & $\begin{array}{l}\text { Q17. Meters 7-10 of composite section on SE tip Dunn "island," (large outcrop } \\
\text { of QI7, 1.5 km SW of Dunn }\end{array}$ \\
\hline DI-4 & $11 \mathrm{~S}$ & 550739 & 3877169 & $\mathrm{X}$ & & $\mathrm{X}$ & & & & $\begin{array}{l}\text { Q17. Meters 10-14 of composite section on SE tip Dunn "island," (large } \\
\text { outcrop of Q17, 1.5 km SW of Dunn }\end{array}$ \\
\hline JR04D-1 & $11 \mathrm{~S}$ & 551349 & 3880423 & $\mathrm{X}$ & $\mathrm{X}$ & & & & $\mathrm{X}$ & $\begin{array}{l}\text { Just basinward of the crest of the highstand barrier Anodonta shells underlie } \\
\sim 25 \mathrm{~cm} \text {-thick foresets and tufa coated cobbles }\end{array}$ \\
\hline JR04D-68 & $11 \mathrm{~S}$ & 555946 & 3877916 & & & $\mathrm{X}$ & & & & Slackwater site (Qysl) \\
\hline JR04CM-77 & $11 \mathrm{~S}$ & 557594 & 3876469 & & & & & & $\mathrm{X}$ & Mojave strath terrace (Qyfmr) overlying Qysl; soil description site \\
\hline JR04CM-78 & $11 \mathrm{~S}$ & 557270 & 3876966 & & & & & & $\mathrm{X}$ & Mojave strath terrace (Qyfmr); soil description site \\
\hline JR04CM-87 & $11 \mathrm{~S}$ & 558726 & 3876339 & & $\mathrm{X}$ & $\mathrm{X}$ & & & $\mathrm{X}$ & $\begin{array}{l}\text { Highest terrace, paleochannel of Mojave River (unit Qif), overlain by } \\
\text { colluvium. Ostracodes for 14C picked from fluvial sand } 3.5 \mathrm{~m} \text { below } \\
\text { surface; also site of OSL age (Reheis and Redwine, 2008) }\end{array}$ \\
\hline JR04CM-88 & $11 \mathrm{~S}$ & 558830 & 3876370 & & & & & & $\mathrm{X}$ & $\begin{array}{l}\text { Highest terrace, paleochannel of Mojave River, overlain by colluvium. Across } \\
\text { arroyo to east from JR04CM- } 87 \text {. }\end{array}$ \\
\hline JR04CM-93 & $11 \mathrm{~S}$ & 557093 & 3877862 & & & $\mathrm{X}$ & & & & $\begin{array}{l}\text { Site is just below big cut. Vertical contact between QTcg (north) and colluvium } \\
\text { (south) which gives way southward to mudflows dominated by boulder } \\
\text { to gravel sized pieces of green lake sediments and of QTcg, overlain by } \\
\text { alluvial sediments with no green lake-sediment clasts. These sediments are } \\
\text { underlain at the south end by strath terraces likely cut by the Mojave River }\end{array}$ \\
\hline
\end{tabular}


Table 3. Site data for Pleistocene Lake Manix surficial map.-Continued

[Sample letters (for example, A, B, and so forth) indicate multiple samples taken from the same section or station]

\begin{tabular}{|c|c|c|c|c|c|c|c|c|c|c|}
\hline Station & UTM & Easting ${ }^{1}$ & Northing & Section & ${ }^{14} \mathrm{C}$ sample & Ostracodes & U-series & Tephra & $\begin{array}{c}\text { Soil } \\
\text { description }\end{array}$ & Description \\
\hline JR04D-95 & $11 \mathrm{~S}$ & 556872 & 3877730 & & & & & & $\mathrm{X}$ & $\begin{array}{l}\text { Soil description site on highest strath terrace located. Surface is eroding and } \\
\text { partially covered by sand, thus soil development is a minimum, yet may } \\
\text { also be enhanced from eolian fines. }\end{array}$ \\
\hline JR04D-98 & $11 \mathrm{~S}$ & 555953 & 3876602 & $\mathrm{X}$ & & $\mathrm{X}$ & & & & $\begin{array}{l}\text { Q17-Q|8 lake sediments described and sampled here. Stratigraphy shows } \\
\text { numerous lake level fluctuations }\end{array}$ \\
\hline JR04D-99 & $11 \mathrm{~S}$ & 555999 & 3876520 & & & $\mathrm{X}$ & & & & $\begin{array}{l}\text { Tufa on unit Qia7 sampled here, very near Norm Meek U-Th dated tufa- } \\
\sim 80 \mathrm{ka} \text { (N. Meek, CSU San Bernardino, personal commun., 2003) }\end{array}$ \\
\hline JR04D-105 & $11 \mathrm{~S}$ & 552788 & 3881504 & & & & & & $\mathrm{X}$ & $\begin{array}{l}\text { Soil description site on late Pleistocene highstand barrier, north of Afton exit. } \\
\text { Hand dug pit with uppermost } 45 \mathrm{~cm} \text { of profile described and sampled. }\end{array}$ \\
\hline JR05D-107 & $11 \mathrm{~S}$ & 552766 & 3881524 & & & & & & $\mathrm{X}$ & $\begin{array}{l}\text { Soil description site on the late Pleistocene highstand barrier, north of the } \\
\text { Afton exit. Exposure on the east side of the barrier with the lower part of } \\
\text { the soil profile described and sampled. }\end{array}$ \\
\hline JR05D-157 & $11 \mathrm{~S}$ & 555969 & 3877942 & & & & & & $\mathrm{X}$ & Soil description site on fan overlying slackwater deposits of site JR04D-68. \\
\hline JR05D-161 & $11 \mathrm{~S}$ & 555908 & 3876567 & $\mathrm{X}$ & & $\mathrm{X}$ & & & & $\begin{array}{l}\text { Q17. On the edge of a vertical cliff beginning to fail. Overlying sandy alluvium } \\
\text { has infiltrated down through these fractures over } 1 \text { meter. }\end{array}$ \\
\hline JR05D-162 & $11 \mathrm{~S}$ & 555907 & 3876606 & & & $\mathrm{X}$ & & & & $\begin{array}{l}\text { Q17. Sampled to compare amino-acid racemization on ostracodes in this } \\
\text { location with at least } 2.5 \text { meters of overlying sediment with those from } \\
\text { nearby site JR04D-98, with only } 1-1.5 \text { meters of overlying sediment }\end{array}$ \\
\hline JR05D-168 & $11 \mathrm{~S}$ & 556323 & 3876209 & $\mathrm{X}$ & & & & & $\mathrm{X}$ & $\begin{array}{l}\text { Section from top of Q17 lake clays through alluvium to Qia7 (dated tufa site } \\
\text { of Meek). Soil description sites (A and B). }\end{array}$ \\
\hline JR05D-194 & $11 \mathrm{~S}$ & 555088 & 3877322 & & & & & & $\mathrm{X}$ & $\begin{array}{l}\text { Soil: Av/Bw/Bwk/Btb with stage I+ to II carbonate morphology. Deposit is } \\
\text { sourced from QTcg and contains some tufa is no longer present uphill }\end{array}$ \\
\hline JR05D-198 & $11 \mathrm{~S}$ & 556983 & 3877763 & & & & & & $\mathrm{X}$ & $\begin{array}{l}\text { Soil description: Av/Bwk(Av2?)/Ck profile with stage I maximum carbonate } \\
\text { morphology }\end{array}$ \\
\hline JR06D-206A & $11 \mathrm{~S}$ & 555095 & 3876179 & $\mathrm{X}$ & $\mathrm{X}$ & & & & & Q18. $0.5 \mathrm{~m}$ below surface of last-highstand beach gravel and sand \\
\hline JR06D-206B & $11 \mathrm{~S}$ & 555095 & 3876179 & & $\mathrm{X}$ & & & & & Q18. $1.5 \mathrm{~m}$ below surface of last-highstand beach gravel and sand \\
\hline JR06D-206C1 & $11 \mathrm{~S}$ & 555095 & 3876179 & & $\mathrm{X}$ & & & & & QI8. $2.5 \mathrm{~m}$ below surface of last-highstand beach gravel and sand \\
\hline JR06D-206E & $11 \mathrm{~S}$ & 555095 & 3876179 & & $\mathrm{X}$ & & & & & $\begin{array}{l}\text { Q18. Top of unit 3, in gravel, nearly intact half-shell, } 1.7 \mathrm{~m} \text { below surface } \\
\text { (below shell B) }\end{array}$ \\
\hline JR06D-206F & $11 \mathrm{~S}$ & 555095 & 3876179 & & $\mathrm{X}$ & & & & & $\begin{array}{l}\text { Q18. Base of unit 2, in gravel, whole shell in growth position } 1.5 \mathrm{~m} \text { below } \\
\text { surface, redate of sample JR06D-206B }\end{array}$ \\
\hline JR06D-202 & $11 \mathrm{~S}$ & 555263 & 3876780 & & & & $\mathrm{X}$ & & & $\begin{array}{l}\text { Basal oncoid tufa (Q17) beneath green mud to west of Norm's S Afton Beach } \\
\text { Ridge section }\end{array}$ \\
\hline JR06D-220 & $11 \mathrm{~S}$ & 553315 & 3876612 & & & & & & $\mathrm{X}$ & $\begin{array}{l}\text { Soil on Qya3 (J.R. Redwine, unpub. data; Qyao of sheet 1, this report): } \sim 3 \mathrm{~cm} \\
\text { Av/Bwk. }\end{array}$ \\
\hline JR06D-221 & $11 \mathrm{~S}$ & 553224 & 3876562 & & & & & & $\mathrm{X}$ & $\begin{array}{l}\text { Soil on Qya3? (Redwine,unpub. data; Qyao of sheet 1, this report). Soil: } \\
8 \mathrm{~cm} \text { eolian cap/C. Sharp crested levees. Bouldery deposit }\end{array}$ \\
\hline JR06D-223 & $11 \mathrm{~S}$ & 552811 & 3876896 & & & & & & $\mathrm{X}$ & $\begin{array}{l}\text { Qya4 or } 5 \text { (J.R. Redwine, unpub. data; Qyao of sheet 1, this report). Flat } \\
\text { surface, sand covered, poor varnish, weak pvement. Soil: } 5-7 \mathrm{~cm} \mathrm{Av/4} \mathrm{cm} \\
\text { B cm with a reddish color. Surface looks younger because of large sand } \\
\text { influence }\end{array}$ \\
\hline
\end{tabular}

${ }^{1}$ All locations given in UTM units, 11S, WGS 84 coordinates 
Table 4. Fault and attitude data for Pleistocene Lake Manix surficial map.

[Sample letters (for example, A, B, and so forth) indicate multiple measurements taken from the same section or station. Att, attributed point not on a fault]

\begin{tabular}{|c|c|c|c|c|c|c|c|}
\hline Station & Easting $^{1}$ & Northing & $\begin{array}{c}\text { Fault } \\
\text { strike } \\
\text { azimuth }\end{array}$ & $\begin{array}{c}\text { Fault } \\
\text { dip } \\
\text { degrees }\end{array}$ & $\begin{array}{l}\text { Bedding } \\
\text { strike } \\
\text { azimuth }\end{array}$ & $\begin{array}{l}\text { Bedding } \\
\text { dip } \\
\text { degrees }\end{array}$ & Notes \\
\hline M04-75 & 542357 & 3871122 & 90 & 85 & & & Two lake units and small fault; upper unit contains shells; overlies lower unit capped by debris flow and paleosol \\
\hline M06-178 & 553942 & 3880341 & 65 & 75 & & & $\begin{array}{l}\text { N65E @ 75SE on cemented shear plane in poorly sorted sand w/floating pebbles. Capped } 2 \mathrm{~m} \text { higher by fan gravel w/ } \\
\text { abundant tufa coats-base QI7? } 50 \mathrm{~m} \text { downslope to W, fault plane seems to jump N but } \mathrm{S} \text { trace continues as prominent } \\
\text { sharp increase in tufa lag on N side and subtle step on surface. Jump in fault also coincides with point where Qia7 tufa } \\
\text { and Q17 base merge (from here upslope) as seen in gullies just to } \mathrm{S} \text { where tufa lines merge and thin green sands between } \\
\text { them pinch out }\end{array}$ \\
\hline M06-182 & 553290 & 3880189 & 65 & 75 & & & $\begin{array}{l}\text { Same fault farther west placing sheared green mud against indurated fan deposits, N65E @ 75S, high-angle reverse. S side } \\
\text { of hill has old eolian sand like that @ M06-178. On W flank of hill, tufa slopes up to 2/3 as high as hilltop, apparently } \\
\text { continuously from Q17 base. Small remnant of thin tufa on E side of hill near top - Qia7? To W along big wash, base } \\
\text { of Q17 is offset down to north along same fault; appears same is true of capping gravel atop Q17 on W side of this wash } \\
\text { except there is no tufa }\end{array}$ \\
\hline M07-73 & 544670 & 3874722 & 42 & 65 & & & $\begin{array}{l}\text { Upper Midway wash @ road crossing between tracks and I-15. Fault N42E @ 65SE, apparently down to SE about } 1 \mathrm{~m} \text { in } \\
\text { Qia7 equivalent. Zone of shear about } 5 \mathrm{~cm} \text { wide }\end{array}$ \\
\hline M07-78 & 545240 & 3871730 & 90 & 90 & & & $\begin{array}{l}\text { Strand of Manix fault S of Buwalda Ridge crest. Vertical, striking due E-W; apparent displacement down to N since gravel } \\
\text { beds bend up approaching fault from N }\end{array}$ \\
\hline M07-89 & 546345 & 3872557 & 10 & 85 & & & Fault striking N10E dipping steeply east cuts the tan pre-lake fan gravel (Qalg or upper Tmr) \\
\hline M07-94 & 546195 & 3872483 & 35 & 85 & & & Western of 2 faults places Q17 mud on E against older pre-mud Qalg on W; N35E @ 80-85 SE. \\
\hline M07-96 & 546025 & 3872274 & 225 & 85 & & & Western of two faults on next ridge to west; cross-valley strike is N35E with dip near vertical, maybe dipping $80-85^{\circ} \mathrm{NW}$ \\
\hline M07-98 & 546261 & 3872187 & 215 & 85 & & & $\begin{array}{l}\text { See new notes p. } 120 \text { in March 2008. Thick pedogenic carbonate on Tbrg (dipping } 25^{\circ} \mathrm{NE} \text { ); terrace displaced about } 1 \mathrm{~m} \\
\text { down to N by fault striking N35E. Soil is overlain by tan distal-fan sediment, unit Qalg }\end{array}$ \\
\hline M07-98Att & 546265 & 3872160 & & & 290 & 8 & $\begin{array}{l}\text { See new notes p. } 120 \text { in March 2008. Thick pedogenic carbonate on Tbrg (dipping } 25^{\circ} \mathrm{NE} \text { ); terrace displaced about } 1 \mathrm{~m} \\
\text { down to N by fault striking N35E. Soil is overlain by tan distal-fan sediment, unit Qalg }\end{array}$ \\
\hline M07-106 & 547190 & 3872164 & 5 & 90 & & & $\begin{array}{l}\text { Tbrg is in fault contact with fill terrace @ site M06-104 (or it is a buttress unconformity). Colluvium @ surface is not } \\
\text { faulted. Vertical shear zone lies@ vertical cliff edge; estimate N5W @ } 90^{\circ}\end{array}$ \\
\hline M07-107A & 546881 & 3871999 & 210 & 75 & & & $\begin{array}{l}\text { Area of M06-94. At mouth of Field wash, "A" is small fault with normal displacement } \sim 2 \mathrm{~m} \text { down to N, displaces Manix } \\
\text { green mud (QI7?) with underlying fan gravel; N30E @ 75NW }\end{array}$ \\
\hline M07-107B & 546811 & 3872021 & 85 & 90 & & & $\begin{array}{l}\text { Area of M06-94, at mouth of Field wash. "B" is major fault running parallel to wash separating Q17 and fan gravel from } \\
\text { Tbrg; N85E @ } 90^{\circ}\end{array}$ \\
\hline M07-120 & 545264 & 3871445 & 265 & 90 & & & $\begin{array}{l}\text { W end of strath terraces where main fault goes into river. Wide shear zone imparts vertical structure to Tbrg. Just to N, } \\
\text { same shear zone bounds a block of Qalg (Qmr) that is nearly flat-lying }\end{array}$ \\
\hline M07-121 & 545335 & 3871369 & 260 & 65 & & & $\begin{array}{l}\text { Another fault N80E @ 65N farther south, puts Tbrg to N against flat-lying Qalg unit. Probable reverse component based on } \\
\text { shear features and stratigraphy }\end{array}$ \\
\hline M07-124 & 545763 & 3871557 & 255 & 90 & & & $\begin{array}{l}\text { Along strike of major fault offsetting youngest Q18 beach gravels, N75E, vertical. Note how Tbrg is faulted against young } \\
\text { beach gravel on N (so apparent offset is down to N) }\end{array}$ \\
\hline M08-31A S fault & 546453 & 3872088 & 40 & 65 & 65 & 5 & $\begin{array}{l}\text { Faults cutting unit Ta and overlying arkosic fan seds. Primary (southern) fault N40E @ 65SE; beds reverse dip across it. } \\
\text { Several smaller faults between }\end{array}$ \\
\hline M08-31B N fault & 546451 & 3872125 & 55 & 58 & 245 & 25 & $\begin{array}{l}\text { Faults cutting unit Ta playa mud and overlying arkosic fan seds (Qalg). Secondary (northern) fault N55E @ 58SE. Normal } \\
\text { down to SE, } 3 \text { m offset of playa mud over Tbrg, beds of both dipping N65E @ 25NW }\end{array}$ \\
\hline M08-38 & 545085 & 3871811 & & & 225 & 5 & $\begin{array}{l}\text { Highest point of red-matrix (Tbrg) unit. } 75 \mathrm{~m} \mathrm{~N} \text {, outcrop of QTalg overlies Tbrg, both dipping } \sim 5-10^{\circ} \mathrm{NE} \text {. Tbrg unit to } \mathrm{S} \\
\text { buried by young sand-ramp deposits, tan, poor sorting, loose }\end{array}$ \\
\hline M08-39 & 545418 & 3871791 & 60 & 90 & & & $\begin{array}{l}2 \text { faults. Red-matrix unit (facies of Tbrg) to N (relatively up) faulted against S-dipping arkosic-lithic fg (Qalg, Qmr); fault } \\
\text { vertical and strike about N60E. Second fault in Qalg against sand-ramp unit. }\end{array}$ \\
\hline M08-41 & 545676 & 3871797 & 60 & 90 & 45 & 15 & $\begin{array}{l}\text { Probable fault, vertical shears and fractures, placing Qalg on N against red-matrix unit (facies of Tbrg) on S (relatively up); } \\
\text { strike parallel to gully, about N60E. Qalg dips } \sim 15^{\circ} \mathrm{SE} \text { and Tbrg } 20^{\circ} \text { or more }\end{array}$ \\
\hline
\end{tabular}


Table 4. Fault and attitude data for Pleistocene Lake Manix surficial map.-Continued

[Sample letters (for example, A, B, and so forth) indicate multiple measurements taken from the same section or station. Att, attributed point not on a fault]

\begin{tabular}{|c|c|c|c|c|c|c|c|}
\hline Station & Easting $^{1}$ & Northing & $\begin{array}{l}\text { Fault } \\
\text { strike } \\
\text { azimuth }\end{array}$ & $\begin{array}{c}\text { Fault } \\
\text { dip } \\
\text { degrees }\end{array}$ & $\begin{array}{l}\text { Bedding } \\
\text { strike } \\
\text { azimuth }\end{array}$ & $\begin{array}{l}\text { Bedding } \\
\text { dip } \\
\text { degrees }\end{array}$ & Notes \\
\hline M08-54 & 545666 & 3871520 & 255 & 90 & & & $\begin{array}{l}\text { Fault contact, Tbrg to } \mathrm{S} \text { and well rounded beach gravel of Q18 to N. N of gray humps of beach gravel, another fault places } \\
\text { Qalg (Qmr?) under beach gravel against Tbrg to N (so up on N). Qalg in middle grades down into Tbrg to N and } \\
\text { downsection, dipping 45SE and vertically fractured; S fault strikes N75E }\end{array}$ \\
\hline M08-54Att & 545666 & 3871535 & & & 45 & 45 & $\begin{array}{l}\text { Fault contact, Tbrg to } \mathrm{S} \text { and well rdd beach gravel of Q18 to N. N of gray humps of beach gravel, another fault places Qalg } \\
\text { (Qmr?) under beach gravel against Tbrg to N (so up on N). Qalg in middle grades down into Tbrg to N and downsection, } \\
\text { dipping } 45^{\circ} \mathrm{SE} \text { and vertically fractured; S fault strikes N75E }\end{array}$ \\
\hline M08-79 & 552437 & 3873840 & 270 & 60 & & & Carbonate-lined small fault in steep cut. Due W @ 60N; N side down about $50 \mathrm{~cm}$; clasts rotated near base. May not break surface \\
\hline M08-80 & 552720 & 3874040 & & & 135 & 20 & Fault scarp cut on older fan gravels that dip 20SW; apparent "down" side to $\mathrm{S}$ is probably younger inset fan \\
\hline M08-81 & 552539 & 3874239 & & & 135 & 20 & $\begin{array}{l}\text { To north of M08-80, same gravels dip 50SW; probably another fault. Older fans are capped to NE by very gently dipping } \\
\text { gravel—an unconformity truncating the dipping gravels }\end{array}$ \\
\hline M08-85 & 551491 & 3874984 & 315 & 90 & & & $\begin{array}{l}\text { Fault or fracture, in sandy debris flow deposits, part of younger fan unit? Apparent vertical fault, strike approx } 345^{\circ} \text {. } \\
\text { Another probable fault } 10 \mathrm{~m} \text { upvalley in fanglomerate }\end{array}$ \\
\hline M08-86 & 551812 & 3875122 & & & 270 & 20 & $\begin{array}{l}\text { Tgg dips } \sim 20 \mathrm{~N} \text { and is folded and faulted; unconformable younger gravel with arkosic sand-ramp beds. Tgg contains strong } \\
\text { calcic paleosol or groundwater carbonate bed with fractures feeding it, locally sheared }\end{array}$ \\
\hline M08-87 & 551868 & 3874770 & & & 290 & 50 & Sandstone beds in Tgg strike110@50N, approaching main wash and Manix fault \\
\hline M08-88 & 552142 & 3874551 & 75 & 85 & 270 & 20 & $\begin{array}{l}\text { Manix fault. Relatively undeformed QTvg on S against highly sheared pink andesite-tuff fanglomerate that forms base of } \\
\text { Tgg. Fault strikes } 75 @ 85 \mathrm{~S} \text {; volc fgl is E-W @ 20N; tuff fanglomerate is vertical and E-W }\end{array}$ \\
\hline M08-88a & 552142 & 3874551 & & & 270 & 90 & $\begin{array}{l}\text { Manix fault. Relatively undeformed QTvg on S against highly sheared pink andesite-tuff fanglomerate that forms base of } \\
\text { Tgg. Fault strikes } 75 @ 85 \mathrm{~S} \text {; volc fgl is E-W @ 20N; tuff fanglomerate is vertical and E-W }\end{array}$ \\
\hline M08-89 & 552285 & 3874623 & & & 80 & 85 & $50 \mathrm{~m}$ north of Manix fault, vertical beds in andesite-tuff fanglomerate \\
\hline M08-90 & 552395 & 3874738 & & & 290 & 85 & $\begin{array}{l}\text { Between M08-89 and 90, granitic clasts appear in the andesite-tuff fanglomerate and increase upsection to N. Attitude here } \\
\text { in sandy beds is } 110 @ 85 \mathrm{~N}\end{array}$ \\
\hline M08-92 & 552483 & 3874593 & 270 & 90 & & & Main Manix fault; abundant clay gouge. Fault strike $270 @ 90$ \\
\hline M08-93 & 551023 & 3874250 & 90 & 70 & & & $\begin{array}{l}\text { Upper limit of tufa coated stones on N side of fault in arroyo; continuous from here to base of section@ @ M08-27; coat line } \\
\text { uplifted to SE. Fault across arroyo, } 270 @ 70 \mathrm{~S} \text {; apparent offset is reverse up to S }\end{array}$ \\
\hline M08-94 & 550951 & 3874187 & 245 & 85 & & & $\begin{array}{l}\text { Fault in main wash to W, view looking east; fault } 65 @ 85 \mathrm{~N} \text {. Matrix-rich reddish arkosic sand on S against more gravelly } \\
\text { unit on N, latter mostly cut out by younger bedded sand and gravel; strikes upvalley between M08-26 and M08-27 }\end{array}$ \\
\hline M08-95 & 550812 & 3874342 & 80 & $80 \mathrm{~S}$ & & & $\begin{array}{l}\text { Fault, strike } 80 @ 80 \text { S. Debris flows on both sides. Appears to truncate a line of tufa-coated stones @ base of M08-26 } \\
\text { outcrop to S, does not seem to reappear on N side of fault }\end{array}$ \\
\hline M08-97 & 551635 & 3875842 & & & 230 & 45 & $\begin{array}{l}\text { Steep-dipping beds of Tgg? along base of steep cuts and capped by younger gravels bedded parallel to wash floor; steep } \\
\text { beds with attitude } 50 @ 45 \mathrm{NW}\end{array}$ \\
\hline M08-98 & 551965 & 3875574 & & & 230 & 25 & $\begin{array}{l}\text { High in badlands of Tgg, dips appear to decrease upward to } \sim 25^{\circ} \text {. Pale blocky massive carbonate caprock on highest } \\
\text { remnants - calcic paleosol? }\end{array}$ \\
\hline M08-99 & 551780 & 3876235 & & & 240 & 12 & $\begin{array}{l}\text { Tgg strikes } 60 @ 12 \mathrm{~N} \text {. Carbonate caprock extends down slope toward river. Tgg appears to be a fanning deposit with dips } \\
\text { decreasing upward }\end{array}$ \\
\hline M08-128 & 540759 & 3871286 & & & 60 & 8 & $\begin{array}{l}\text { Contact of Q14 and mod. indurated upper Qalg. Q14 mostly loose well-bedded sand. Attitude from basal } 1.5 \mathrm{~m} \text { of Qalg: } \\
60 \text { @ 8SE; above this, beds more gravelly and nearly flat-lying. Unconformity? }\end{array}$ \\
\hline M08-130 & 540973 & 3871581 & 90 & 75 & & & $\begin{array}{l}\text { Point is base of Q17 capping outcrop; overlies } 270 \mathrm{~cm} \text { Q15, lake-marginal fluvial deposits, tufa coats @ top, over } 130 \mathrm{~cm} \\
\text { x-bedded fluvial sand to cobble gravel; overlies 10-15 cm Bwk imposed on greenish-brown mud of QI4, blocky to thinly } \\
\text { bedded. Reverse fault strike E-W @ 75S near base, apparently up to S, steepens upward; offsets buried soil by } \sim 60 \mathrm{~cm} \text {, } \\
\text { sand bed } 1 \mathrm{~m} \text { higher by only } \sim 20 \mathrm{~cm} \text {; Q17 @ top stops @ fault }\end{array}$ \\
\hline M08-131 & 541168 & 3871803 & 90 & 75 & & & $\begin{array}{l}\text { Point is on fault, strat. about } 2 \mathrm{~m} \text { above base of Q17, but base quite deformed (see photos); apparent offset } 40 \mathrm{~cm} \text {. Similar } \\
\text { dip and strike to that @ M08-130. Two lake units cap Q17 here; middle one is either cut out or locally inset into Q17, and } \\
\text { Q17 thickens to east incorporating this interval }\end{array}$ \\
\hline
\end{tabular}


[Sample letters (for example, A, B, and so forth) indicate multiple measurements taken from the same section or station. Att, attributed point not on a fault]

\begin{tabular}{|c|c|c|c|c|c|c|c|}
\hline Station & Easting $^{1}$ & Northing & $\begin{array}{l}\text { Fault } \\
\text { strike } \\
\text { azimuth }\end{array}$ & $\begin{array}{c}\text { Fault } \\
\text { dip } \\
\text { degrees }\end{array}$ & $\begin{array}{l}\text { Bedding } \\
\text { strike } \\
\text { azimuth }\end{array}$ & $\begin{array}{l}\text { Bedding } \\
\text { dip } \\
\text { degrees }\end{array}$ & Notes \\
\hline M08-136 & 541563 & 3871338 & & & 135 & 8 & $\begin{array}{l}\text { To east of M08-135 up drainage. Attitude } \sim 135 @ 8 \mathrm{SW} \text { on stratified indurated sand, mud and gravel; probably unit Qalg } \\
\text { mapped to east. } 3 \mathrm{~m} \text { thick above wash, overlain @ angular unconf. and tufa line by } \sim 60 \mathrm{~cm} \text { nearshore sand of QI4, } \\
\text { overlain by } \sim 2 \mathrm{~m} \text { stratified, mod-weakly sorted sand and gravel. Fault likely @ upstream end of outcrop where contact is } \\
\text { lower; } 25 \mathrm{~m} \text { farther upstream, Qalg and unconformity both strongly tilted }\end{array}$ \\
\hline M08-142 & 540920 & 3871142 & 300 & $90 ?$ & 140 & 15 & $\begin{array}{l}\text { Manix fault strand. Base of Q14 marked by sorted gravel with tufa coats at top of Q15 lake-marginal? alluvium. Q14 folded } \\
\text { on E-W monoclinal axis; this fault offsets the fold limb. Overlain by well washed arkosic pebble gravel and sand } \\
\text { (beach?) of QI5. Bed attitude S of fault } 40 \text { @ } 15 \mathrm{NE} \text {. }\end{array}$ \\
\hline M08-143 & 540830 & 3871108 & & & 110 & 22 & Folded Qalg $110 @ 22 \mathrm{E}$ (08-410). Slopes to S underlain by a salt-rich muddy unit, poorly exposed, likely playa deposits of Qmr \\
\hline M08-144 & 541199 & 3871058 & 90 & 90 & & & $\begin{array}{l}\text { Main Manix fault?, due E-W, vertical. Many shears in low wash cut place Qalg on N against possible slices of Q/4 and } \\
\text { then lake sand and mud of Q14. Qalg } 1.5 \mathrm{~m} \text { thick capped by thickly tufa-coated Buwalda-type clasts, in turn overlain by } \\
\text { Q14 as measured in section M08-60 just to east. Apparent offset } \sim 2.4 \mathrm{~m} \text { down to S }\end{array}$ \\
\hline M08-150 & 541841 & 3871219 & 240 & 75 & & & $\begin{array}{l}\text { Beds similar to basal ones @ M08-149, capped by base of Q14? Adjacent is strongly carbonate-cemented fault or shear } \\
\text { exposed in wash bed; some planes indicate } 240 \text { @ 75N }\end{array}$ \\
\hline M08-150att & 541841 & 3871240 & & & 135 & 30 & $\begin{array}{l}\text { Beds similar to basal ones @ M08-149, capped by base of Q14? Adjacent is strongly carbonate-cemented fault or shear } \\
\text { exposed in wash bed; some planes indicate } 240 \text { @ 75N }\end{array}$ \\
\hline M08-159 & 542702 & 3870131 & & & 230 & 7 & $\begin{array}{l}\text { Attitude } 140 @ 7 \mathrm{NE} \text { on thin sandstone interbedded with Qmr muds, N end of outcrop on butte } \mathrm{N} \text { of river. Flat surface } \\
\text { @ toe of steep slope is Mojave River strath (Qyfmr) }\end{array}$ \\
\hline M08-160 & 542754 & 3870006 & & & 20 & 2 & $\begin{array}{l}\text { Attitude } 20 @ 2 \text { SE on central part of butte. Overlain by } 3 \mathrm{~m} \text { Mojave River gravel and sand (Qyfmr) mixed with Cady } \\
\text { Mtn. fan gravel }\end{array}$ \\
\hline M08-164 & 542667 & 3868988 & 70 & 65 & & & 18-cm tephra in $\mathrm{Qmr}, 50 \mathrm{~m} \mathrm{~N}$ of M08-163. Sediments dip $12^{\circ} \mathrm{SW}$. Cut by fault striking $70^{\circ}$, vertical, down to $\mathrm{S}$ by $2.5 \mathrm{~m}$ \\
\hline M08-183 & 541784 & 3868355 & 25 & 90 & & & $\begin{array}{l}\text { Prominent fault outcrop, apparently down to E since Q17 occurs on that side but on W, Q18 lies on Qvg; several m displacement; } \\
\text { Qvg bent strongly up on hanging wall approaching fault; } 25^{\circ} \text { @ vertical (see sketch). Base of Q14? Top of Qvg rises 2-3 m to } \\
\text { N across a swale, with no Q14 present to N but 3-4 m Q14 to S }\end{array}$ \\
\hline M08-185 & 541662 & 3867964 & 25 & 90 & & & Fault zone in Qvg resembles the one @ M08-83: complex set of shears, apparent down to S, attitude 25 @ vertical \\
\hline M08-199 & 552760 & 3874586 & 90 & 90 & & & $\begin{array}{l}\text { Manix Fault, volc fgl (QTvg) on S and pink andesite tuff bedrock, another fault with andesite tuff against andesitic tuff fgl. } \\
\text { Fault plane } 90 @ \text { vertical, slickenlines plunge } 20-40^{\circ} \mathrm{E} \text {, left-lateral mullion configuration }\end{array}$ \\
\hline M09-7 & 542683 & 3868959 & 155 & & & & $\begin{array}{l}\text { East side of hill @ site M08-164. Fault N25W down to W. Tufa line @ base of Q17 apparently down to N } \sim 50 \mathrm{~cm} \text {, and } \\
\text { Huckleberry Ridge ash @ top on S side fault faulted down } \sim 4 \mathrm{~m}\end{array}$ \\
\hline M09-8 & 542597 & 3869016 & 270 & & & & Apparent E-W strike on small fault; Huckleberry Ridge ash offset $1 \mathrm{~m}$ down to N. Little or no offset of base of Manix beds \\
\hline M09-9 & 541720 & 3868408 & 80 & 80 & & & $\begin{array}{l}\text { N80E @ 80S on cemented fault zone exposed in wash floor between M08-182 and 183. Faulted unit is like Tbrg but unbedded. } \\
\text { Another fault zone N70E about 15-20 m upstream in same unit. No apparent offfset of lake beds }\end{array}$ \\
\hline M09-10 & 541760 & 3868367 & 245 & 65 & & & N65E @ 65 NW, fault in gully just W of M08-183. Displaces interbedded Qmr-Qvg unit down to NW \\
\hline M09-19 & 541245 & 3867475 & 185 & 80 & & & $\begin{array}{l}\text { GPS point is poor due to slot canyon walls. Fault down to W; drops Qvg against volcs. N5E and N20W on cemented shears } \\
\text { in wash floor; dip is } 75-80^{\circ} \mathrm{W} \text {. Fault in volcanics }\end{array}$ \\
\hline M09-19A & 541280 & 3867425 & 75 & 75 & & & $\begin{array}{l}50 \text { m upcanyon of M09-19 and 100-150 m downstream of M09-18 is another fault in volcs (no GPS possible). Down to S; } \\
\text { drops platy andesite against underlying reddish andesite. N75E @ } 75 \text { SE, steeper @ top }\end{array}$ \\
\hline M09-20 & 541419 & 3867571 & 15 & 85 & & & $\begin{array}{l}\text { Fault in Qvg, N15E @ 85E. One fanglomerate bed } \sim 4 \mathrm{~m} \text { below Manix beds is down } \sim 2 \mathrm{~m} \text { to E, and carbonate-filled fractures } \\
\text { line face to E of fault }\end{array}$ \\
\hline M09-21 & 541486 & 3867504 & 200 & 80 & & & Fault in Qvg, N20E@80W; drag indicates down to W. Cemented shear zone crosses wash bottom \\
\hline M09-22 & 541579 & 3867469 & 0 & 90 & & & Poorly exposed fault in Qvg. Strikes N about vertical, somewhat exposed on SW-facing slope \\
\hline M09-27 & 541663 & 3867962 & 195 & 80 & & & Fault in Qvg. N15E@80W. Wide shear zone in gravels, multiple strands, 2-3 m wide@ base \\
\hline M09-36 & 541597 & 3870510 & 230 & 80 & & & $\begin{array}{l}\text { Fault zone, E side Manix wash nearest river, prominently cuts Qmr. At least } 4 \text { offsets along multiple strands and shears } \\
\text { and fractures along } \sim 50 \mathrm{~m} \text { of wash cut. Two northern are down to S, 1-m offsets. Two southern are down to N; but } \\
\text { some striae are subhorizontal on all faults. S fault is N50E @ } 80 \mathrm{NW} \text { with curving fault plane; next N is E-W @ } 55 \mathrm{~S} \text {; } \\
\text { northernmost is N30E @ 75SE. Uppermost Qmr has interfingers of Qalg-type sand and gravel and soils. N end of } \\
\text { outcrop has Qalg unconformable on Qmr. Souhthernmost fault. }\end{array}$ \\
\hline
\end{tabular}


Table 4. Fault and attitude data for Pleistocene Lake Manix surficial map.-Continued

[Sample letters (for example, A, B, and so forth) indicate multiple measurements taken from the same section or station. Att, attributed point not on a fault]

\begin{tabular}{|c|c|c|c|c|c|c|c|}
\hline Station & Easting $^{1}$ & Northing & $\begin{array}{l}\text { Fault } \\
\text { strike } \\
\text { azimuth }\end{array}$ & $\begin{array}{l}\text { Fault } \\
\text { dip } \\
\text { degrees }\end{array}$ & $\begin{array}{l}\text { Bedding } \\
\text { strike } \\
\text { azimuth }\end{array}$ & $\begin{array}{l}\text { Bedding } \\
\text { dip } \\
\text { degrees }\end{array}$ & Notes \\
\hline M09-36 & 541597 & 3870510 & 90 & 55 & & & $\begin{array}{l}\text { Fault zone, E side Manix wash nearest river, prominently cuts Qmr. At least } 4 \text { offsets along multiple strands and shears } \\
\text { and fractures along 50 m of wash cut. Two northern are down to S, 1-m offsets. Two southern are down to N; but some } \\
\text { striae are subhorizontal on all faults. S fault is N50E @ 80NW with curving fault plane; next N is E-W @ 55S; northern- } \\
\text { most is N30E @ 75SE. Uppermost Qmr has interfingers of Qalg-type sand and gravel and soils. N end of outcrop has } \\
\text { Qalg unconformable on Qmr. Next fault to North }\end{array}$ \\
\hline M09-36 & 541597 & 3870510 & 30 & 75 & & & $\begin{array}{l}\text { Fault zone, E side Manix wash nearest river, prominently cuts Qmr. At least } 4 \text { offsets along multiple strands and shears and } \\
\text { fractures along } \sim 50 \mathrm{~m} \text { of wash cut. Two northern are down to S, 1-m offsets. Two southern are down to N; but some striae } \\
\text { are subhorizontal on all faults. S fault is N50E @ 80NW with curving fault plane; next N is E-W @ 55S; northernmost } \\
\text { is N30E @ 75SE. Uppermost Qmr has interfingers of Qalg-type sand and gravel and soils. N end of outcrop has Qalg } \\
\text { unconformable on Qmr. Northernmost fault. }\end{array}$ \\
\hline M09-45 & 542871 & 3868809 & 15 & 75 & & & $\begin{array}{l}\text { Pair of faults bound a horst of Qmr, here } 2.5 \mathrm{~m} \text { thick with Huckleberry Ridge ash just above wash floor. East fault: } \\
\text { N15E @ } 75 \text { E, down to E. } 2 \mathrm{~m} \text { of lacustrine sand over Qvg on E side of horst is missing from the horst, and both sand } \\
\text { and Qvg are truncated by fan gravel of Qia6 overlain by Q17 }\end{array}$ \\
\hline M09-45A & 542864 & 3868815 & 205 & 80 & & & $\begin{array}{l}\text { Pair of faults bound a horst of Qmr, here } 2 \text { m thick with Huckleberry Ridge ash just above wash floor. West fault: N25E @ 80W, } \\
\text { down to W }\end{array}$ \\
\hline M09-46 & 542944 & 3868826 & 30 & 85 & & & $\begin{array}{l}\text { Fault, N30E @ 85SE down to SE, bounding fault of horst block of Qmr, as much as } 6 \mathrm{~m} \text { thick with Huckleberry Ridge } \\
\text { ash } \sim 1.5 \mathrm{~m} \text { below gradational contact with overlying Qvg; another very thin white ash above wash floor. Fault poorly } \\
\text { exposed, mostly a shear zone in Qmr muds on wash floor }\end{array}$ \\
\hline M09-46A & 542917 & 3868932 & 220 & 80 & & & Fault on west side of horst block, N40E @ 78NW, where thickest part of Qmr faulted against Qvg; minimum 6 m throw \\
\hline M09-48 & 542787 & 3868968 & & & 0 & 20 & $\begin{array}{l}\text { Top of Qmr. N @ 20E on bedding in Huckleberry Ridge ash. Qmr interbedded with cobble fan-gravel beds of Qvg; about } \\
4 \text { m of Qmr-type seds above ash to point where Qvg-type gravel dominates. Suspect fault or fold between here and next } \\
\text { bluff west (M08-163) because there, Qmr appears flat-lying }\end{array}$ \\
\hline M09-49 & 543027 & 3868895 & 190 & 80 & & & Fault, N10E@80W. Qvg down to west against Qmr \\
\hline M09-50 & 543095 & 3868835 & 15 & 85 & & & Pair of faults. N15E @ 85E down to E, Qvg against Qmr, minimum 5 m offset \\
\hline M09-50A & 543079 & 3868859 & 190 & 90 & & & Pair of faults. Approx. N10E, down to W. Top of Qmr under Qvg steps down $\sim 2-3 \mathrm{~m}$ \\
\hline M09-51 & 543124 & 3868785 & 195 & 90 & & & $\begin{array}{l}\text { Fault up same wash, } \sim \mathrm{N} 15 \mathrm{E} \text {, exposed as shear zone in wash floor but clearly down to W because } 1.5 \mathrm{~m} \text { of Qmr is exposed } \\
\text { east of fault }\end{array}$ \\
\hline M09-53 & 543332 & 3868875 & 190 & 75 & & & $\begin{array}{l}\text { Fault in Qvg, N10E@ @ 75W, probably down to W, carbonate-cemented. Probably another fault just to W with same strike } \\
\text { where Qmr pops up again }\end{array}$ \\
\hline M09-62 & 541880 & 3868976 & 235 & 85 & & & $\begin{array}{l}\text { Fault, cuts Qvg, N55E @ 85NW, down to W. Possibly reaches a surface scarp cutting lake unit, but more likely scarp is } \\
\text { fluvial; Qyfmr strath gravel lies on top. Strong drag of cobbles along fault in footwall block }\end{array}$ \\
\hline M09-64 & 541942 & 3868764 & 340 & 65 & & & Reverse fault, N20W @ 65NE, in Qvg. 3 m up on NE side. Overlying lake beds not offset \\
\hline M09-82 & 542706 & 3868853 & 205 & & & & $\begin{array}{l}\text { Inferred fault, N25 E, up to SE. Required, to separate area to SE with Qia7/Q17/Qvg from area to NW with Qia7/Q17/ } \\
\text { Q16/Q15?/Q14?/Qmr. Contact of Qia7/Q17 even seems higher on SE side }\end{array}$ \\
\hline M09-97 & 541512 & 3871063 & 260 & 75 & 210 & 15 & $\begin{array}{l}\text { Complicated set of } 4 \text { ? faults cutting QI4 and underlying Qalg, with a faulted fold. See drawings and notes, p. 82-83. } \\
\text { Southern fault is N80E @ 75N. Qalg on both sides N45W @ 15SW }\end{array}$ \\
\hline M09-97A & 541502 & 3871066 & 295 & 75 & & & Middle fault $\sim \mathrm{N} 65 \mathrm{~W} @ 75 \mathrm{NE}$, LL strike-slip. Beds west of scissor N30E @ $15 \mathrm{NW}$; east of scissor, dipping $15^{\circ} \mathrm{E}$ \\
\hline M09-97B & 541508 & 3871079 & 260 & 90 & & & Northern fault N80E @ 90, apparently down to N. Beds N of N fault N60E @ 15SE \\
\hline M09-98 & 541428 & 3871025 & 255 & 75 & 135 & 15 & Aligned notches trend N75E, to S of prev. fault complex. Fault, N75E @ 75N, apparently down to N \\
\hline M09-99 & 541910 & 3871091 & 95 & 90 & & & $\begin{array}{l}\text { Fault, Qalg on both sides. Qalg/Qmr contact about } 4 \mathrm{~m} \text { stratigraphically below this to the S. Carbonate-cemented vertical } \\
\text { shears, N85W. Another fault or pair of faults } 3 \mathrm{~m} \text { to N in Qalg; contact with lake deposits is near top of ridge to N }\end{array}$ \\
\hline M09-100 & 541982 & 3871096 & 275 & 85 & & & 2 faults merge to form a 3.5-m-wide shear zone in Qalg. N85W @ 85N \\
\hline M09-103 & 542301 & 3871086 & 265 & 75 & & & $\begin{array}{l}\text { Southern of two faults, this one @ base of a very steep escarpment and between Qmr to S and Qalg to N of fault. Here, } \\
\text { Qalg looks much like a sand ramp, dips steeply SW and is quite fractured. N85E @ 75N, apparent down to N. Qalg } \\
\text { attitude is N45W@65N }\end{array}$ \\
\hline
\end{tabular}


Table 4. Fault and attitude data for Pleistocene Lake Manix surficial map.-Continued

[Sample letters (for example, A, B, and so forth) indicate multiple measurements taken from the same section or station. Att, attributed point not on a fault]

\begin{tabular}{|c|c|c|c|c|c|c|c|}
\hline Station & Easting ${ }^{1}$ & Northing & $\begin{array}{c}\text { Fault } \\
\text { strike } \\
\text { azimuth }\end{array}$ & $\begin{array}{l}\text { Fault } \\
\text { dip } \\
\text { degrees }\end{array}$ & $\begin{array}{l}\text { Bedding } \\
\text { strike } \\
\text { azimuth }\end{array}$ & $\begin{array}{l}\text { Bedding } \\
\text { dip } \\
\text { degrees }\end{array}$ & Notes \\
\hline M09-103att & 542280 & 3871131 & & & 315 & 65 & $\begin{array}{l}\text { Southern of two faults, this one @ base of a very steep escarpment and between Qmr to S and Qalg to N of fault. Here, } \\
\text { Qalg looks much like a sand ramp, dips steeply SW and is quite fractured. N85E @ 75N, apparent down to N. Qalg } \\
\text { attitude is N45W@65N }\end{array}$ \\
\hline M09-103A & 542300 & 3871111 & 270 & 65 & & & $\begin{array}{l}\text { Northern of two faults, this near top of escarpment; steep-dipping Qalg on S side and horizontal QI7? sand/gravel beds on } \\
\text { N side; E-W @ 65N }\end{array}$ \\
\hline M09-104 & 542361 & 3871011 & & & 235 & 6 & Just to S of escarpment, N55E @ 6NW on sandstone bed in Qmr \\
\hline M09-105 & 542633 & 3870937 & & & 260 & 15 & N80E @ $15 \mathrm{~N}$ on bedding in Qmr, south of all faults; no faults exposed here \\
\hline M09-106 & 552544 & 3874610 & 245 & 65 & & & $\begin{array}{l}\text { Subsidiary fault in andesitic tuff fanglomerate, } \mathrm{N} \text { of main Manix fault, abundant vertical slickenlines. QTvg to } \mathrm{S} \text { has local } \\
\text { thick interbeds of eolian sand }\end{array}$ \\
\hline M09-108 & 542924 & 3871142 & & & 90 & 35 & $\begin{array}{l}\text { Very close to fault; here, N side of anticline, which was N-dipping, is now steeply S-dippping; E-W @ 35S and appears to } \\
\text { go near vertical in badlands just to N }\end{array}$ \\
\hline M09-110 & 552891 & 3874586 & 95 & 90 & & & Manix fault, sheared gunge of andesitic tuff, against QTvg. N85W@ vertical \\
\hline M09-112 & 553060 & 3874566 & 255 & 65 & & & N75W@65N on fault separating QTvg? from QTvg with red volcanic gunge dragged into fault plane \\
\hline M09-114 & 553214 & 3874609 & 260 & 70 & & & $\begin{array}{l}\text { Fault N80E @ 70N between gunge on N and QTvg on S. Also cuts horizontally bedded Qia that overlies QTvg in angular } \\
\text { unconformity. Appears channeled into QTvg and has >1 sandy red calcic soils; likely reworked off old Tgg early in } \\
\text { dissection and is more like the age of Qvg }\end{array}$ \\
\hline M09-117 & 553203 & 3874546 & 100 & $\mathrm{~S}$ & 270 & 65 & $\begin{array}{l}\text { Fault bounds S side of red basalt (Tvs) against QTvg, N80W @ 90. To N, QTvg overlies red basalt and is tilted up to } \sim 65 \text { dip } \\
\text { to N, separated from near flat-lying QTvg by fault striking N70W @ 65NE. Section capped by young disconformable Qia } \\
\text { (M09-114) }\end{array}$ \\
\hline M09-118 & 553110 & 3874535 & 230 & 45 & & & $\begin{array}{l}\text { Crazy unconformities in QTvg. Lower beds N20W @ 35SW, upper beds N20E @ 60NW. 2/27/11: new attitude on lower } \\
\text { beds, N5W @ 45W, mafic volcanic gravel with 1-2\% phenocrystic granites. Overlain in fault contact by large-clast fgl } \\
\text { (basal QTvg) with abundant very dense med-gray xlline granitoids, with attitude N10W @ 85W. Fault has dip direction } \\
45 @ \text { N40W. A few meters upstream/downsection, very large rounded boulders of andesite and andesite breccia are } \\
\text { interbedded with finer-clast mafic beds, some dense gray xlline granitoids too }\end{array}$ \\
\hline M09-118Attlo & 553102 & 3874519 & & & 175 & 45 & $\begin{array}{l}\text { Crazy unconformities in QTvg. Lower beds N20W @ 35SW, upper beds N20E @ 60NW. 2/27/11: new attitude on lower } \\
\text { beds, N5W @ 45W, mafic volcanic gravel with 1-2\% phenocrystic granites. Overlain in fault contact by large-clast fgl } \\
\text { (basal QTvg) with abundant very dense med-gray xlline granitoids, with attitude N10W @ 85W. Fault has dip direction } \\
45 @ \text { N40W. A few meters upstream/downsection, very large rounded boulders of andesite and andesite breccia are } \\
\text { interbedded with finer-clast mafic beds, some dense gray xlline granitoids too }\end{array}$ \\
\hline M09-130 & 546212 & 3871672 & 255 & 90 & & & $\begin{array}{l}\text { Another fault in same zone and attitude; N75E near vertical. Q17 down to N, here against Qalg, but seems to reverse throw } \\
\text { to east }\end{array}$ \\
\hline M09-131 & 546163 & 3871699 & 70 & 90 & & & $\begin{array}{l}\text { Fault or steep fold or both. N65-70E. On N side is a cobble lag from Buwalda Ridge that seems to correspond to transgressive } \\
\text { base of Q17 tufa cobbles to N. On S side, beach sand and green mud are dipping gently NE but then bend up steeply to a SE } \\
\text { dip of } 60^{\circ} \text {. Likely folded up to a fault contact with Qalg to NW }\end{array}$ \\
\hline M09-132 & 544910 & 3871709 & 270 & 85 & 245 & 10 & $\begin{array}{l}\text { Fault cuts Tbrg here; in spur just to E, cuts old talus dipping } 40^{\circ} \text { and places in probable fault contact with Tbrg dipping } \\
\sim 10^{\circ} \mathrm{N} \text { or NNW. Fault is E-W @ } 85 \mathrm{~S} \text {. Younger inset talus cones don't appear to be offset }\end{array}$ \\
\hline M09-135 & 543341 & 3871287 & 75 & 65 & & & Multiple faults overall placing Tbrg against Manix lake units. N fault N75E @ 65SE, faults Tbrg (both sides) dipping $\sim 15^{\circ} \mathrm{S}$ \\
\hline M09-135Att & 543341 & 3871310 & & & 75 & 15 & Multiple faults overall placing Tbrg against Manix lake units. N fault N75E @ 65SE, faults Tbrg (both sides) dipping $\sim 15^{\circ} \mathrm{S}$ \\
\hline M09-135A & 543352 & 3871276 & 75 & 65 & & & $\begin{array}{l}\text { Middle fault } \sim \text { N75E @ 65SE, LL strike-slip. Displaces tufa stone line } 2.5 \mathrm{~m} \text { down to N; several small parallel faults. Lake beds } \\
\text { dip } 15^{\circ} \mathrm{S} \text {. Several stone lines over } \sim 2 \mathrm{~m} \text { interval tufa-coated. Looks like reworked Qalg with stone lines of BR clasts. }\end{array}$ \\
\hline M09-135Att & 543352 & 3871250 & & & 255 & 15 & $\begin{array}{l}\text { Middle fault N N5E @ 65SE, LL strike-slip. Displaces tufa stone line } 2.5 \mathrm{~m} \text { down to N; several small parallel faults. Lake beds } \\
\text { dip } 15^{\circ} \mathrm{S} \text {. Several stone lines over } \sim 2 \mathrm{~m} \text { interval tufa-coated. Looks like reworked Qalg with stone lines of BR clasts. }\end{array}$ \\
\hline
\end{tabular}


Table 4. Fault and attitude data for Pleistocene Lake Manix surficial map.-Continued

[Sample letters (for example, A, B, and so forth) indicate multiple measurements taken from the same section or station. Att, attributed point not on a fault]

\begin{tabular}{|c|c|c|c|c|c|c|c|}
\hline Station & Easting $^{1}$ & Northing & $\begin{array}{c}\text { Fault } \\
\text { strike } \\
\text { azimuth }\end{array}$ & $\begin{array}{c}\text { Fault } \\
\text { dip } \\
\text { degrees }\end{array}$ & $\begin{array}{l}\text { Bedding } \\
\text { strike } \\
\text { azimuth }\end{array}$ & $\begin{array}{l}\text { Bedding } \\
\text { dip } \\
\text { degrees }\end{array}$ & Notes \\
\hline M09-135B & 543358 & 3871229 & 260 & 75 & & & $\begin{array}{l}\text { S fault, N80E @ 75N. Lake unit overlies a gravelly volcanic-clast-rich version of Qalg—looks like large amounts of eolian } \\
\text { sand interbedded with fan gravel. In fault contact on S with Qmr, attidtude N70E @ 20N. Sandy-fan unit dips } 40^{\circ} \mathrm{N} \\
\text { near the fault; looks like a slight angular unconformity with overlying Qalg unit that interfingers with lake deposits. See } \\
\text { sketch in field notes p. } 101\end{array}$ \\
\hline M09-135B & 543358 & 3871200 & & & 250 & 20 & $\begin{array}{l}\text { S fault, N80E @ 75N. Lake unit overlies a gravelly volcanic-clast-rich version of Qalg_-looks like large amounts of eolian } \\
\text { sand interbedded with fan gravel. In fault contact on S with Qmr, attidtude N70E @ 20N. Sandy-fan unit dips } 40^{\circ} \mathrm{N} \\
\text { near the fault; looks like a slight angular unconformity with overlying Qalg unit that interfingers with lake deposits. } \\
\text { See sketch in field notes p. } 101\end{array}$ \\
\hline M10-13 & 557518 & 3874488 & 290 & 75 & & & $\begin{array}{l}\text { Fault contact of Tgg of this study and fluvial-lacustrine sediment of Tvs unit (QTg and Tu of Mosely, 1978). N75W @ 75N. } \\
\text { Red clay gouge, } 1 \mathrm{~m} \text { wide shear }\end{array}$ \\
\hline M10-18 & 557342 & 3874584 & 270 & 75 & & & $\begin{array}{l}\text { Fault contact of Tvs to S (Tu of Mosely, 1978) and Tgg to N. Nearly parallel to bedding but has slickenlines of clay } \\
\text { gouge @ contact. E-W @ 70-75 N }\end{array}$ \\
\hline M10-19 & 557244 & 3874626 & 290 & 70 & 290 & 70 & $\begin{array}{l}\text { Fault contact of Qia (fine-pebble basaltic clasts) on S with Qia derived from Tgg on N. Below these units, fault is between } \\
\text { Tgg on N and Tvs (Tu of Mosely, 1978) on S. Tgg dips 70 N, same as fault; N70W @ 70N }\end{array}$ \\
\hline M10-20 & 557113 & 3874716 & 90 & 80 & & & $\begin{array}{l}\text { Fault in Tgg, many conjugate shears. Mean zone has shear fabric } 1 \text { m wide. E-W @ 80S. N65W @ 35SE (up to 45) } \\
\text { plunge on slickenlines. }\end{array}$ \\
\hline M10-21 & 557070 & 3874732 & 110 & 80 & & & $\begin{array}{l}\text { Fault, N70W @ 70S curving up to near vertical. Contact of gouged olivine-rich basalt on S thrust over Tgg on N. Main } \\
\text { fault of Tvs-Tgg lies a few meters to S so this basalt is faulted into the Tgg. Horizontal slickenlines in gouge }\end{array}$ \\
\hline M10-22 & 556783 & 3874887 & 110 & 90 & & & $\begin{array}{l}\text { Fault in Tvs unit between Mosely (1978) units Tb3 on S and Ts on N; Ts only } 1.5 \mathrm{~m} \text { thick, in turn faulted against Tgg. Both } \\
\text { faults vertical and merge just to east. Striae N70W }\end{array}$ \\
\hline M10-23 & 556616 & 3875515 & 260 & 85 & & & $\begin{array}{l}\text { Fault in Tgg, N80E @ 85N. Close to contact with Tgg and overlying finer-grained darker volcaniclastic fanglomerate } \\
\text { (QTvg?). Some soils in Tgg and here overall much finer grained; fines toward top, QTvg looks conformable on it }\end{array}$ \\
\hline M10-24 & 556451 & 3875047 & 285 & 77 & & & $\begin{array}{l}\text { Fault, N50W @ 77NE cross-valley strike on fault measured by Dave Miller (USGS) in slot canyon. Tgg to SW against Tvs } \\
\text { on NE. Apparent offset is down to NE in upper part, where younger horizontally bedded Qvg overlies Tgg and basalt } \\
\text { and is lower to NE, but lower down is opposite. Tvs in turn faulted against green fluvial sandstone, thin, channeled into } \\
\text { basalt; that fault strikes E-W @ } 77 \mathrm{~N}\end{array}$ \\
\hline M10-25 & 556457 & 3874866 & 235 & 72 & & & $\begin{array}{l}\text { Fault, N55E @ 72NW places airfall tuff to NW against Mosely (1978) units Ts4? over Tb3? Overlying QTvg not clearly } \\
\text { displaced to NE. But to SW, QTvg is down } 75 \mathrm{~m} \text { to NW against Ts4(?). At least two angular unconformities in } \\
\text { "younger" gravel package (QTvg and Qvg?) }\end{array}$ \\
\hline M10-30 & 555895 & 3874993 & & & 135 & 25 & $\begin{array}{l}\text { Main Manix fault puts } 20-25^{\circ} \mathrm{SW} \text {-dipping QTvg, overlain by flat-lying Qvg, to } \mathrm{N} \text { against Tvs (including thin Peach } \\
\text { Springs Tuff) on S. Another fault } 15 \mathrm{~m} \text { north offsets only QTvg, not overlying Qvg }\end{array}$ \\
\hline M10-32 & 555638 & 3874928 & 255 & 90 & & & $\begin{array}{l}\text { Same fault shot back to M10-31 from west, N75E@90. Qvg@ GPS point faulted against Tvs (Ts of Mosely, 1978) with } \\
\text { clasts rotated vertical in fault zone }\end{array}$ \\
\hline M10-36 & 554747 & 3874833 & 90 & 88 & & & $\begin{array}{l}\text { Fault, E-W@ @ 88S. Tvs faulted against eolian sand (Qiea) 7-8 m thick. Clay gouge @ fault. Some lineations horizontal, } \\
\text { some plunge } 25^{\circ} \mathrm{W}\end{array}$ \\
\hline M10-37 & 554455 & 3874604 & 245 & 75 & & & Fault, N65E@75 NW. QTvg on NW against Tvs on SE. Mostly debris flows; to NE, QTvg appears to dip $>45^{\circ}$ into fault \\
\hline M10-38 & 554307 & 3874506 & 245 & 75 & & & $\begin{array}{l}\text { Same fault as M10-37. Here a fan and eolian (Qia and Qye) unit with strong stage III carbonate below surface drapes a } \\
\text { S-dipping contact on top of QTvg, here with clasts in sandy matrix, locally well bedded }\end{array}$ \\
\hline M10-56 & 543067 & 3870942 & & & 205 & 9 & $\begin{array}{l}\text { N25E @ 9NW attitude on Qmr bedded silt-sand above massive red-brown playa beds. To west, beds curve into broad anticline } \\
\text { and farther west are dipping westward }\end{array}$ \\
\hline M10-57 & 542979 & 3871055 & & & 0 & 7 & N-S @ 7E attitude on fluvially bedded distal-fan deposits of Qalg (upper Qmr). $5 \mathrm{~m}$ above red-brown Qmr-Qalg contact \\
\hline M10-58 & 542862 & 3871099 & & & 315 & 5 & N45W@5NE on fluvial bed in Qalg, 6 m below contact with strong buried soil on basaltic gravel shed from Buwalda Ridge \\
\hline
\end{tabular}


Table 4. Fault and attitude data for Pleistocene Lake Manix surficial map.-Continued

[Sample letters (for example, A, B, and so forth) indicate multiple measurements taken from the same section or station. Att, attributed point not on a fault]

\begin{tabular}{|c|c|c|c|c|c|c|c|}
\hline Station & Easting $^{1}$ & Northing & $\begin{array}{l}\text { Fault } \\
\text { strike } \\
\text { azimuth }\end{array}$ & $\begin{array}{c}\text { Fault } \\
\text { dip } \\
\text { degrees }\end{array}$ & $\begin{array}{l}\text { Bedding } \\
\text { strike } \\
\text { azimuth }\end{array}$ & $\begin{array}{l}\text { Bedding } \\
\text { dip } \\
\text { degrees }\end{array}$ & Notes \\
\hline M10-66 & 542914 & 3871064 & & & 120 & 5 & $\begin{array}{l}\text { N60W @ 5SW, attitude on fluvial ss in Qalg near axis of syncline trending N65W. A parallel anticline lies just to NE and } \\
\text { then beds turn up abruptly along main fault to dip S. However, lake beds not involved in folding nor apparently the upper } \\
\text { several m of Qalg; appears to have an angular unconformity within Qalg, marked by soil (can’t access; see photos and } \\
\text { sketch). Beds above dip SSW @ 15-20 }\end{array}$ \\
\hline M10-67 & 542937 & 3871131 & 285 & 87 & & & $\begin{array}{l}\text { Fault, N75W @ 87N on fault placing older playa Qmr on N, very steeply dipping, against arkosic Qalg (upper Qmr), } \\
\text { which dips } 20^{\circ} \mathrm{S} \text { near fault but approaches horizontal a few meters S; so, apparent drag on fault, down to S }\end{array}$ \\
\hline M10-68 & 543073 & 3871187 & 250 & 80 & & & $\begin{array}{l}\text { Fault, N70E@80NW with playa facies Qmr, containing carbonate nodules, dipping } 60^{\circ} \mathrm{SW} \text { on S, against flat lying to } \\
\text { steep-dipping (depositional dip) Buwalda-Ridge derived fan gravel interbedded with probable lake sand: very well } \\
\text { sorted, slightly greenish, @ least } 2 \text { beds, multiple sets of opposing crossbeds }\end{array}$ \\
\hline M10-70 & 543139 & 3871232 & 90 & 90 & & & $\begin{array}{l}\text { Fault, E-W @ 90. Bedded Buwalda Ridge-derived fan gravel and interbedded eolian sand on } \mathrm{N} \text { against same unit (?) on S. } \\
\text { To N is horizontally bedded, to } \mathrm{S} \text { too sheared up to tell, maybe N-dipping. } 2 \text { other parallel faults to } \mathrm{S}\end{array}$ \\
\hline M10-71 & 543165 & 3871225 & 255 & 85 & & & Fault, N75E @ 85N. Same interbedded gravel-sand beds down to N against Qmr, arkosic facies? \\
\hline M10-77A & 548583 & 3872904 & 60 & 90 & & & $\begin{array}{l}\text { Same block bounded on SE by probable fault, N60E, strikes directly @ top of Tbrg ridgetop. Marked by zone of reddish } \\
\text { clayey sand, probably dragged from underlying playa deposits? }\end{array}$ \\
\hline M10-82 & 543154 & 3871114 & & & 120 & 10 & $\begin{array}{l}\text { N60W @ 10SW on cemented muddy ss. Break about } 1 / 2 \text { way up Qmr between massive salty beds below to thinner bedded } \\
\text { arkosic sand and pebble gravel with less mud. Hard to define on ground; transitional change here. Sandstone may mark } \\
\text { unconformity to SW shown in photo? }\end{array}$ \\
\hline M10-87 & 542858 & 3871066 & 255 & 60 & & & $\begin{array}{l}\text { N60E @ 60N on fault, cuts upper Qmr and cuts off the abrupt clifftop contact with overlying arkosic alluvium (Qia). } \\
\text { Possibly down to N but loses cemented zone; still grayer above and redder below. To west, contact is plain and marked } \\
\text { by color change and cemented bed. 2-m wedge of Buwalda-derived gravel caps Qia @ an erosional unconformity, in } \\
\text { turn overlain by several m of lake deposits, @ least } 2 \text { units }\end{array}$ \\
\hline M10-89 & 542911 & 3871110 & 255 & 65 & & & Same fault as M10-87, here N60E @ 65N \\
\hline M10-101 & 542252 & 3871037 & 225 & 80 & & & $\begin{array}{l}\text { Carbonate associated with a fault zone, here a carbonate-cemented shear, N45E @ } 80 \mathrm{NW} \text {. Revisit 2/24/11, beds to S of small } \\
\text { fault below red-carb marker bed dip } 7^{\circ} \mathrm{N} \text {; beds to N, including red marker, dip as much as } 13^{\circ} \mathrm{S} \text {. Fault is about @ fold axis }\end{array}$ \\
\hline M10-101att & 542252 & 3871000 & & & 225 & 7 & $\begin{array}{l}\text { Carbonate associated with a fault zone, here a carbonate-cemented shear, N45E @ } 80 \mathrm{NW} \text {. Revisit 2/24/11, beds to S of small } \\
\text { fault below red-carb marker bed dip } 7^{\circ} \mathrm{N} \text {; beds to N, including red marker, dip as much as } 13^{\circ} \mathrm{S} \text {. Fault is about @ fold axis }\end{array}$ \\
\hline M11-13 & 548647 & 3873615 & 280 & 75 & & & $\begin{array}{l}\text { Fault, N80W @ } 75 \mathrm{~N} \text {, cuts both Qof units and Ta. Here, } 3 \mathrm{~m} \text { down to } \mathrm{S} \text { on inter-Qof soil beneath well-bedded sand, so a } \\
\text { reverse fault. Playa unit Ta @ least } 5.5 \mathrm{~m} \text { thick adjacent to fault and upper } 2.5 \mathrm{~m} \text { quite gravelly }\end{array}$ \\
\hline M11-24 & 544613 & 3874915 & & & & 4 & Older, pinkish arkosic sediment (QTalg), E bank Field wash, dipping about $4^{\circ} \mathrm{SE}$; mostly massive sand \\
\hline M11-25 & 544978 & 3874650 & & & & 5 & $\begin{array}{l}\text { Basal pinkish unit (QTalg) dipping } 5^{\circ} \mathrm{SE} \text { makes up half of outcrop. Upper half is bedded sand and gravel interpreted as } \\
\text { Q17 overlain by } \sim 2 \mathrm{~m} \text { Qia7 }\end{array}$ \\
\hline M11-27 & 541174 & 3873503 & & & 155 & 10 & $\begin{array}{l}\text { On Yermo road. Beds dipping } \sim 10^{\circ} \mathrm{S} 55 \mathrm{~W} \text {. Pinkish, stratified gravel and sand, matrix-rich, weathered granites - QTalg. } \\
\text { Upper pebble-cobble bed has some rhyolite and quartzite }\end{array}$ \\
\hline M11-29 & 546563 & 3872339 & & & 180 & 28 & North of camp. N-S @ $28^{\circ} \mathrm{W}$ on base of sand unit in playa deposits (unit Ta). \\
\hline M11-31 & 546525 & 3872299 & 250 & 80 & & & $\begin{array}{l}\text { Fault, N70E@ @ 80N. 2-3 closely spaced shears place playa-fan deposits (Ta) on N against mafic, fine-grained debris-flow } \\
\text { unit on S (Tbrg) }\end{array}$ \\
\hline M11-33 & 548370 & 3872962 & & & 290 & 10 & $\begin{array}{l}\text { N70W @ } 10 \mathrm{NE} \text { on playa beds }(\mathrm{Ta}) \text { with thin }(30-50 \mathrm{~cm}) \text { pebble-coarse sand beds. Just to NE are more gravelly beds near } \\
\text { top below capping strath (Qyfmr) }\end{array}$ \\
\hline M11-38 & 544645 & 3871113 & 25 & 82 & & & $\begin{array}{l}\text { Fault, N25E@82S, down to west (reverse) suggested by small drag on beds @ fault, but big fold on E side fault suggests normal, } \\
\text { down to east in Qmr @ tight fold, between sites M10-90 and tephra M07-128. Last winter flood exposed fault @ tip of fold } \\
\text { not seen previously }\end{array}$ \\
\hline M11-40 & 541934 & 3871051 & 235 & 65 & & & $\begin{array}{l}\text { Small fault, N55E @ } 65 \mathrm{NW} \text {, likely down to NW, little displacement. All these little faults near the main ones probably contributed } \\
\text { to abundant groundwater carbonate cement in this area. About where I thought there might be a fault but this has different } \\
\text { strike; nothing prominent }\end{array}$ \\
\hline
\end{tabular}


Table 4. Fault and attitude data for Pleistocene Lake Manix surficial map.—Continued

[Sample letters (for example, A, B, and so forth) indicate multiple measurements taken from the same section or station. Att, attributed point not on a fault]

\begin{tabular}{|c|c|c|c|c|c|c|c|}
\hline Station & Easting $^{1}$ & Northing & $\begin{array}{c}\text { Fault } \\
\text { strike } \\
\text { azimuth }\end{array}$ & $\begin{array}{c}\text { Fault } \\
\text { dip } \\
\text { degrees }\end{array}$ & $\begin{array}{l}\text { Bedding } \\
\text { strike } \\
\text { azimuth }\end{array}$ & $\begin{array}{c}\text { Bedding } \\
\text { dip } \\
\text { degrees }\end{array}$ & Notes \\
\hline M11-47 & 552590 & 3874769 & & & 340 & 45 & $\begin{array}{l}\text { Dip } 45^{\circ} \mathrm{N} 70 \mathrm{E} \text {. Largely granitic gravels }(\mathrm{Tgg}) \mathrm{w} / 5 \% \text { of dense dark brown aphanitic rocks with green mineralization - a skarn? } \\
25 \% \text { andesite. Just above is pale-colored dominantly sand unit } 7-8 \mathrm{~m} \text { thick. }\end{array}$ \\
\hline M11-48 & 552661 & 3874833 & & & 330 & 45 & $\begin{array}{l}\text { Top of sand unit in Tgg. Attitude N30W @ } 45 \mathrm{NE} \text { as above. } \mathrm{x} \text {-bedded but flow direction unclear. Above here, gravel dominates } \\
\text { to top of Tgg. Sand unit is } \sim 50 \mathrm{~m} \text { wide along dip direction so....25 m thick? }\end{array}$ \\
\hline M11-52 & 553468 & 3874561 & & & 10 & 15 & $\begin{array}{l}\text { Above basalt (Tvs), steadily upsection through monotonous volcaniclastic gravel, mostly andesite, some basalt and rhyolite; } \\
\text { no granites (unit QTvg). Attitude N10E @ 15E }\end{array}$ \\
\hline M11-54 & 553700 & 3874298 & & & 140 & 10 & $\begin{array}{l}\text { Big boulder QTvg lies on top of basalt; flow top worked up into base of fanglomerate? Same as described @ M10-40 to } \\
\text { east, lots of granites and flow-banded rhyolite reworked from unit Tqg. This bouldery lag continues right up to highest } \\
\text { point on ridge to west. In cut below, dip direction S50W @ } 10\end{array}$ \\
\hline M11-57 & 552867 & 3873878 & & & 200 & 8 & $\begin{array}{l}\text { Outcrop of felsic-aphanitic igneous rock: green/pink and strongly foliated. Abutted to E by tilted granitic fan gravel (Qia) } \\
\text { w/very angular clasts: dip direction N70W @ } 8^{\circ} \text {. Fan gravel probably faulted against outcrop; hints that gravel is turned } \\
\text { up as if rotated in shear near bedrock }\end{array}$ \\
\hline M11-60 & 552285 & 3873968 & & & 180 & 11 & $\begin{array}{l}\text { Qvg containing abundant granite clasts. Dip direction } 11^{\circ} \mathrm{W} \text {. Tilt seems to be increasing downslope... approaching fault? } \\
\text { Rocks are subangular and } \sim 70 \% \text { or more granitoids }\end{array}$ \\
\hline JR05CM-167 & 556311 & 3876335 & 80 & 90 & & & $\begin{array}{l}\text { Splay of the Manix fault, N80E, dipping near vertical, apparent down to the north offset } \sim 5.8 \text { meters in Q17 lacustrine } \\
\text { deposits. Qia7 gravels are probably also offset. There is a much thicker package of fan material on the downthrown side } \\
\text { of the fault }\end{array}$ \\
\hline JR05CM-169 & 556531 & 3876305 & 80 & 90 & & & $\begin{array}{l}\text { Manix fault, 'Lidke splay'? N80E, appears to project through wide shear zone on the north side of the Mojave River. If it } \\
\text { does, it cuts the shear zone and the major fault in the shear zone which dips @ } 86 \text { degrees to the south, reactivating it }\end{array}$ \\
\hline M12-6 & 554084 & 3874116 & & & 140 & 25 & Sandstone bed in Tqg; attitude S40E @ 25 NE. Crossbeds suggest SW flow \\
\hline M12-11 & 553875 & 3874237 & & & 195 & 11 & $\begin{array}{l}\text { QTvg dips } 11^{\circ} \mathrm{S} 15 \mathrm{~W} \text {. Cut by fault with attitude N10E @ } 90 \text {. Rake on slickenlines } 45^{\circ} \mathrm{S} \text {. Steps on slick faces are on S ends } \\
\text { and thus indicate right-lateral motion }\end{array}$ \\
\hline M12-15 & 553220 & 3874392 & & & 320 & 42 & $\begin{array}{l}\text { N40W@42SW on QTvg@ approx level where rhyolite and granitoid clasts become scarce; appears the Tqg-bearing } \\
\text { fanglomerate is a basal unit of non-Tqg fangomerate }\end{array}$ \\
\hline
\end{tabular}

${ }^{1}$ All locations given in UTM units, 11S, WGS 84 coordinates 
Publishing support provided by:

Denver Publishing Service Center, Denver, Colorado

For more information concerning this publication, contact:

Center Director, USGS Geosciences and Environmental Change Science Center

Box 25046, Mail Stop 980

Denver, CO 80225

(303) 236-5344

Or visit the Geosciences and Environmental Change Science Center Web site at: http://gec.cr.usgs.gov/

This publication is available online at:

http://dx.doi.org/10.3133/sim3312 
